Prepared in cooperation with the West Virginia Department of Transportation, Division of Highways and the West Virginia Conservation Agency

\title{
Regional Curves for Bankfull Channel Characteristics in the Appalachian Plateaus, West Virginia
}

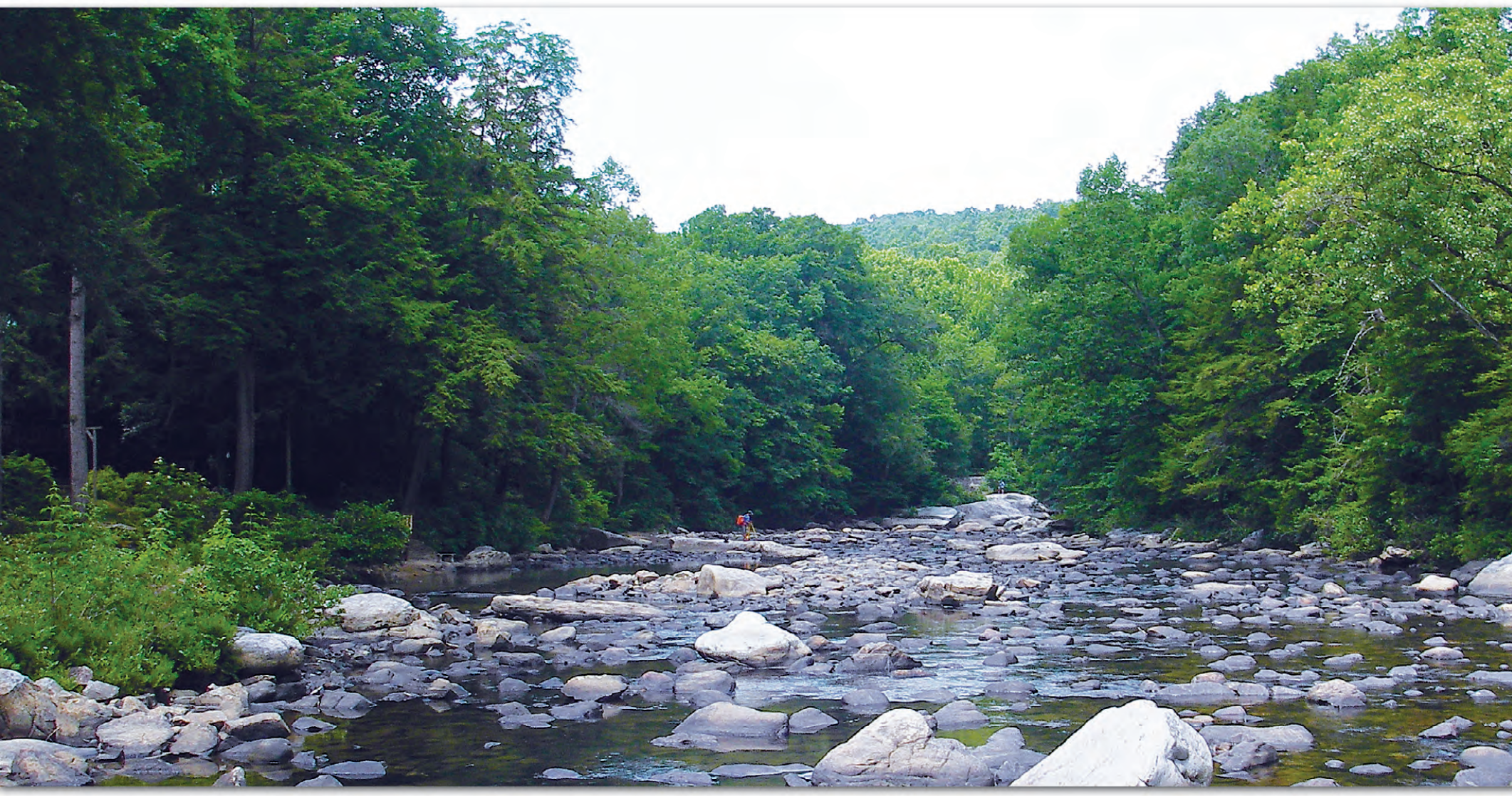

Scientific Investigations Report 2009-5242 
Cover. James Scott (U.S. Geological Survey, West Virginia Water Science Center) sets up to survey at Middle Fork at Audra, West Virginia. 


\title{
Regional Curves for Bankfull Channel Characteristics in the Appalachian Plateaus, West Virginia
}

\author{
By Terence Messinger
}

Prepared in cooperation with the West Virginia Department of Transportation, Division of Highways and the West Virginia Conservation Agency

Scientific Investigations Report 2009-5242 


\title{
U.S. Department of the Interior \\ KEN SALAZAR, Secretary \\ U.S. Geological Survey \\ Marcia K. McNutt, Director
}

\section{U.S. Geological Survey, Reston, Virginia: 2009}

\author{
For more information on the USGS — the Federal source for science about the Earth, its natural and living resources, \\ natural hazards, and the environment, visit http://www.usgs.gov or call 1-888-ASK-USGS \\ For an overview of USGS information products, including maps, imagery, and publications, \\ visit http://www.usgs.gov/pubprod \\ To order this and other USGS information products, visit http://store.usgs.gov
}

Any use of trade, product, or firm names is for descriptive purposes only and does not imply endorsement by the U.S. Government.

Although this report is in the public domain, permission must be secured from the individual copyright owners to reproduce any copyrighted materials contained within this report.

Suggested citation:

Messinger, Terence, 2009, Regional curves for bankfull channel characteristics in the Appalachian Plateaus, West Virginia: U.S. Geological Survey Scientific Investigations Report 2009-5242, 43 p. 


\section{Contents}

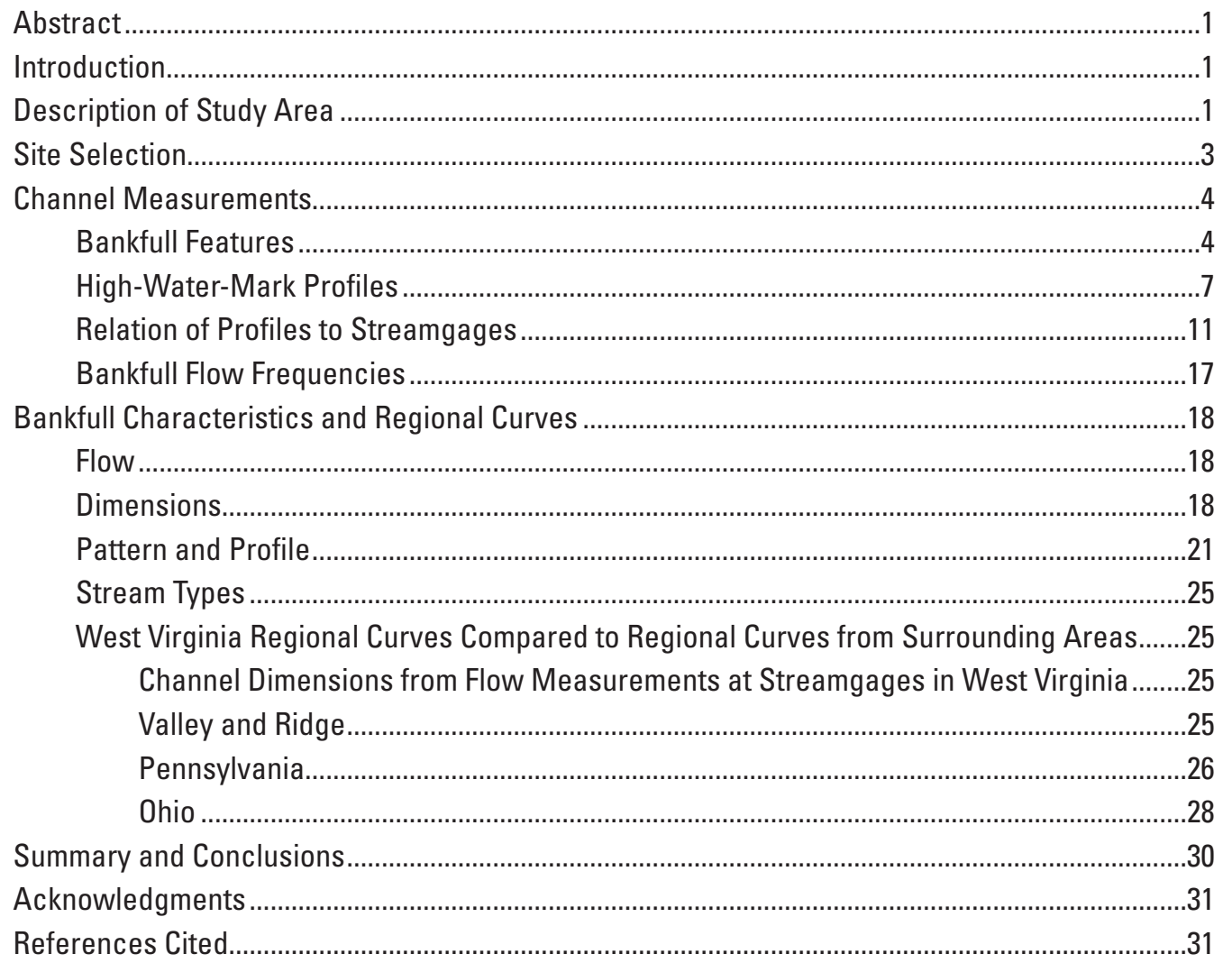




\section{Figures}

1-3. Maps showing -

1. West Virginia and surrounding states, their physiography, and selected cities and rivers

2. Regional curve planning regions, elevation, mean annual precipitation, and recent streamgages on unregulated streams in West Virginia...

3. Regional curve sites in the Appalachian Plateaus Physiographic Province, West Virginia

4-6. Graphs showing-

4. Profiles of selected gaged stream channels in the Appalachian Plateaus Physiographic Province of West Virginia

5. Profiles of selected ungaged stream channels in the Appalachian Plateaus Physiographic Province of West Virginia

6. Selected profiles of high-water marks from near-bankfull peaks, bankfull features, low-water surface, and thalwegs for reaches at streamgages at

$(A)$ Middle Fork at Audra and (B) Panther Creek near Panther, West Virginia .......14

7. Photograph of crest-stage streamgage at Marsh Fork at Maben, West Virginia ...........16

8-18. Graphs showing-

8. 1.5-year peak flow at streamgages draining less than 240 square miles in the Appalachian Plateaus Physiographic Province, West Virginia, by region and end year of systematic record..

9. Relation between bankfull flow and drainage area for selected wadable streams in the Appalachian Plateaus Physiographic Province in West Virginia

10. Bankfull flows compared to 1.5-year peak flows measured at streamgages on wadable streams in the Appalachian Plateaus Physiographic Province in West Virginia

11. Bankfull flows compared to regression lines for 1.2-, 1.4-, 1.5-, and 1.7-year peak flows measured at streamgages on wadable streams in the Appalachian Plateaus Physiographic Province in West Virginia.

12. Relation between bankfull area and drainage area for wadable streams in the Appalachian Plateaus Physiographic Province in West Virginia

13. Relation between bankfull width and drainage area for wadable streams in the Appalachian Plateaus Physiographic Province in West Virginia

14. Relation between bankfull depth and drainage area for wadable streams in the Appalachian Plateaus Physiographic Province in West Virginia

15. Regional curve and 99-percent confidence interval for bankfull area of wadable streams in the Appalachian Plateaus Province in West Virginia, compared to curves developed for adjacent areas

16. Regional curve and 99-percent confidence interval for bankfull width of wadable streams in the Appalachian Plateaus Province in West Virginia, compared to curves developed for adjacent areas

17. Regional curve and 99-percent confidence interval for bankfull depth of wadable streams in the Appalachian Plateaus Province in West Virginia, compared to curves developed for adjacent areas

18. Regional curve and 99-percent confidence interval for bankfull flow of wadable streams in the Appalachian Plateaus Province in West Virginia, compared to curves developed for adjacent areas. 


\section{Tables}

1. Station numbers, drainage areas, locations, and streamgaging periods of record for regional curve sites for the Appalachian Plateaus Physiographic Province, West Virginia .....

2. Description of bankfull features, sediment particle size, and Manning's roughness coefficient for stream cross sections in the Appalachian Plateaus Physiographic Province, West Virginia

3. Dates of peak flows, flagging, description of storms, and quality and type of marks for high-water profiles and slope-area flow measurements made during regional curve development for the Appalachian Plateaus Physiographic Province, West Virginia

4. Bankfull dimensions and other characteristics of stream cross sections in the Appalachian Plateaus Physiographic Province in West Virginia

5. Average bankfull characteristics of streams in the Appalachian Plateaus Physiographic Province in West Virginia .....

6. Bankfull characteristics and stream types of reaches in the Appalachian Plateaus Physiographic Province in West Virginia 


\section{Conversion Factors and Datums}

\begin{tabular}{|c|c|c|}
\hline Multiply & By & To obtain \\
\hline \multicolumn{3}{|c|}{ Length } \\
\hline foot $(\mathrm{ft})$ & 0.3048 & meter $(\mathrm{m})$ \\
\hline mile (mi) & 1.609 & kilometer (km) \\
\hline \multicolumn{3}{|c|}{ Area } \\
\hline square foot $\left(\mathrm{ft}^{2}\right)$ & 0.09290 & square meter $\left(\mathrm{m}^{2}\right)$ \\
\hline square mile $\left(\mathrm{mi}^{2}\right)$ & 2.590 & square kilometer $\left(\mathrm{km}^{2}\right)$ \\
\hline \multicolumn{3}{|c|}{ Flow rate } \\
\hline cubic foot per second $\left(\mathrm{ft}^{3} / \mathrm{s}\right)$ & 0.02832 & cubic meter per second $\left(\mathrm{m}^{3} / \mathrm{s}\right)$ \\
\hline
\end{tabular}

Temperature in degrees Celsius $\left({ }^{\circ} \mathrm{C}\right)$ may be converted to degrees Fahrenheit $\left({ }^{\circ} \mathrm{F}\right)$ as follows:

${ }^{\circ} \mathrm{F}=\left(1.8 \mathrm{x}^{\circ} \mathrm{C}\right)+32$

Temperature in degrees Fahrenheit $\left({ }^{\circ} \mathrm{F}\right)$ may be converted to degrees Celsius $\left({ }^{\circ} \mathrm{C}\right)$ as follows:

${ }^{\circ} \mathrm{C}=\left({ }^{\circ} \mathrm{F}-32\right) / 1.8$

Vertical coordinate information is referenced to the North American Vertical Datum of 1988 (NAVD 88).

Horizontal coordinate information is referenced to the North American Datum of 1983 (NAD 83). Altitude, as used in this report, refers to distance above the vertical datum. 


\title{
Regional Curves for Bankfull Channel Characteristics in the Appalachian Plateaus, West Virginia
}

\author{
By Terence Messinger
}

\section{Abstract}

Streams in the Appalachian Plateaus Physiographic Province in West Virginia were classified as a single region on the basis of bankfull characteristics. Regression lines for annual peak flow and drainage area measured at streamgages in the study area at recurrence intervals between 1.2 and 1.7 years fell within the 99-percent confidence interval of the regression line for bankfull flow. Channel characteristics were intermediate among those from surrounding states and regions where comparable studies have been done.

The stream reaches that were surveyed were selected for apparent stability, and to represent gradients of drainage area, elevation, and mean annual precipitation. Profiles of high-water marks left by bankfull and near-bankfull peaks were surveyed, either as part of slope-area flow measurements at ungaged reaches, or to transfer known flow information to cross sections for gaged reaches. The slope-area measurements made it possible to include ungaged sites in the study, but still relate bankfull dimensions to peak flow and frequency.

\section{Introduction}

Regional curves (Dunne and Leopold, 1978) are regression equations that quantify relations within a region between bankfull channel characteristics and drainage area, and in some cases, other basin characteristics. They are used in natural channel design (NCD), which is a set of methods for restoring, rebuilding, or rerouting stream channels (Rosgen, 1996). Natural channel design practitioners use regional curves to design channels or to verify identification of bankfull features in reference reaches.

Stream restoration, of which NCD is a subset, is important in environmental management and policy and has become a growing business (Bernhardt and others, 2005). The National River Restoration Science Synthesis (NRRSS) project estimated that at least $\$ 14$ to $\$ 15$ billion was spent on restoration of streams and rivers within the continental United States between 1990 and 2005 (Bernhardt, 2006; Bernhardt and others, 2005). Channel reconfiguration projects, a category which includes NCD, accounted for more than $\$ 1.3$ billion of the overall total.

The concept of bankfull flow is central to NCD (Leopold, 1994; Rosgen, 1996). Dimension, pattern, and profile of channels are considered to be maintained by bankfull flow, which is considered to be the effective flow or the flow that transports the most cumulative sediment over time (Rosgen, 1996). Bankfull flow, regardless of whether or not it is the effective flow, usually has a return period between 1 and 2 years when calculated from the annual-peak series, with 1.5 years close to average (Leopold and others, 1964). Stable channels, by definition, are changed little by flows of magnitudes that recur frequently, but channel instability can result from land-use and other changes that alter the magnitude of frequent peak flows.

The West Virginia Conservation Agency and the Division of Highways of the West Virginia Department of Transportation cooperated with the U.S. Geological Survey (USGS) in this project, one of a series of studies done in and near West Virginia, intended to provide information for NCD (Wiley and others, 2002; Messinger and Wiley, 2004; Keaton and others, 2005). The Canaan Valley Institute facilitated the task force that identified the need for this series of studies.

The purpose of this report is to provide regional equations (regional curves) for bankfull characteristics of stable stream channels within the part of the Appalachian Plateaus Physiographic Province in West Virginia. Supporting information is provided on the development of the regional curves. Bankfull stream-channel characteristics are compared to those of adjacent regions.

\section{Description of Study Area}

The study area was defined as the part of West Virginia within the Appalachian Plateaus Physiographic Province (fig. 1). The Appalachian Plateaus Physiographic Province is an area of flat-lying or gently folded rocks that formed when a peneplain was uplifted during the Appalachian Orogeny, and then was dissected by stream erosion in the ensuing 


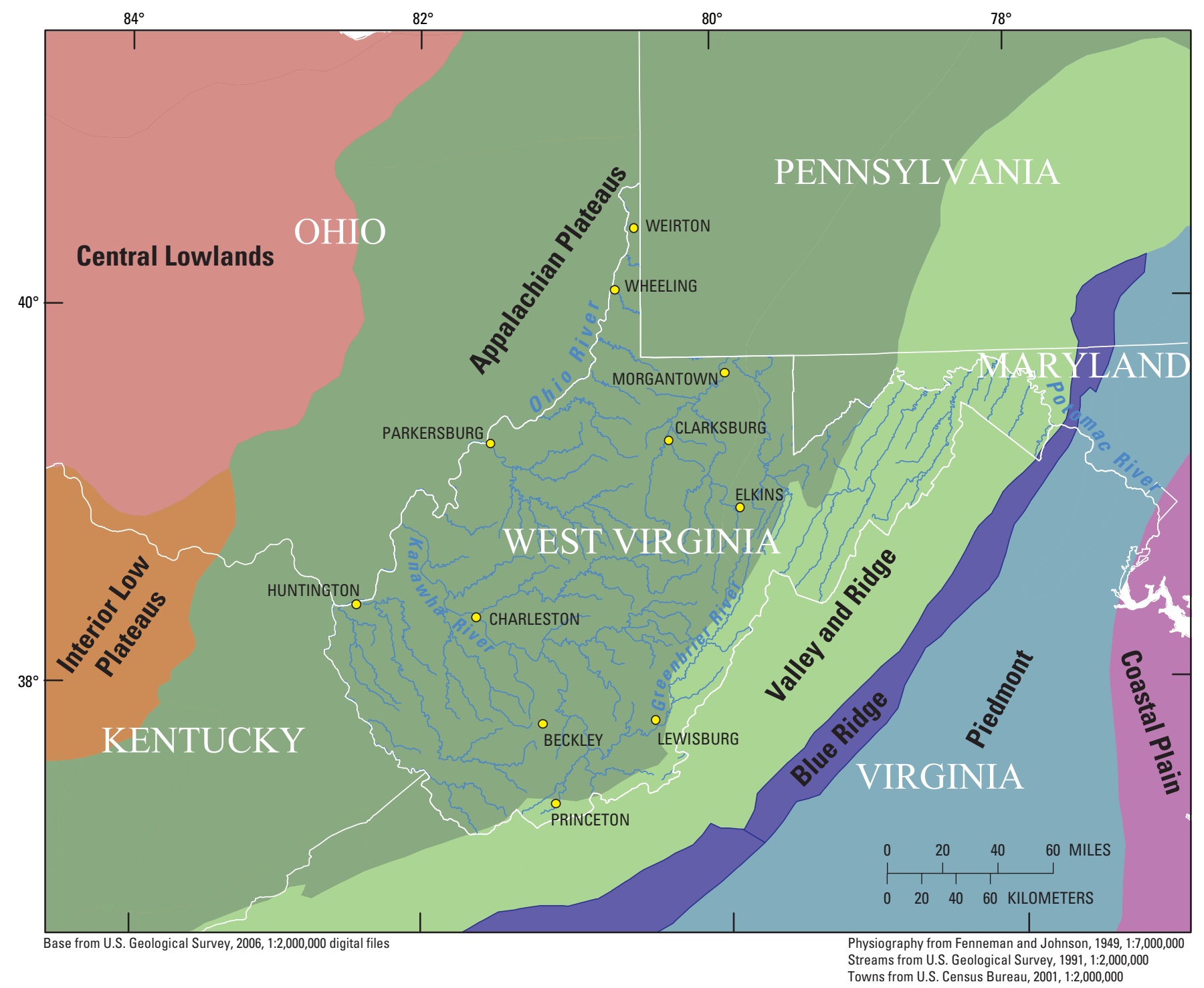

Figure 1. West Virginia and surrounding states, their physiography, and selected cities and rivers. The study area is the part of the Appalachian Plateaus Physiographic Province within West Virginia.

300 million years (Fenneman, 1938). Elevation is highest in the east, where some peaks are higher than 4,000 ft (NAVD 88), and lowest in the west, near the Ohio River, where the valley is lower than $600 \mathrm{ft}$ (fig. 2). Relief is generally greatest at highest elevations. The Ohio River drains most of the study area $\left(19,631 \mathrm{mi}^{2}\right)$, and the rest $\left(329 \mathrm{mi}^{2}\right)$ is drained by the Potomac River.

Mean annual precipitation and maximum storm precipitation are not closely correlated. Maximum storm precipitation, as measured by any of several frequencies for storm intensity, is greatest in the southern and eastern parts of the study area and least in the northern and western parts of the study area (Hydrometeorological Design Studies Center, 2006a, 2006b).
The eastern part of the study area is more frequently affected by Atlantic hurricanes than is the west, which accounts, in part, for the difference. Distribution of mean annual precipitation is related closely to elevation, and the greatest annual precipitation is received in the highest parts of the study area. The lowest mean annual precipitation in the study area is in the Northern Panhandle and the southern Greenbrier River Basin in the southeastern part of the study area, which is behind a pronounced rain shadow (fig. 2).

Land use, surface geology, and soils all covary with elevation within the study area (Messinger and Hughes, 2000). Generally, the highest population density and concentration of urban land is in river valleys in the northern and western parts 
of the study area. Commercial agriculture is limited in scope, and most commercial farms are near the downstream sections of the Ohio and Kanawha Rivers, and the Greenbrier River Basin. Forest cover is most dense in the mountains in central West Virginia. The largest cities in the study area, all with populations less than 51,000, are Charleston on the Kanawha River; Huntington, Parkersburg, and Wheeling on the Ohio River; and Morgantown on the Monongahela River (U.S. Census Bureau, 2009). Because the largest urban areas in the study area are in the valleys of major rivers, increases in peak storm runoff caused by impervious urban lands are generally localized and most pronounced on a few small streams.

Principal economic activities include coal mining, forestry, and oil and gas production, which are widespread throughout most of the study area; manufacturing, which is most common in areas near the Monongahela, Ohio, and Kanawha Rivers; and agriculture, which is most important commercially near the Ohio and Kanawha Rivers and in the
Greenbrier River Basin (Messinger and Hughes, 2000). Of these, forestry and surface coal mining are widespread within the study area and have well-established, strong effects on storm hydrographs and peak flows.

\section{Site Selection}

Planning regions were developed for this study on the basis of elevation and mean annual precipitation, which were the basin characteristics that explained the most variation in near-bankfull channel characteristics determined from analysis of flow measurements made at streamgages (Messinger and Wiley, 2004). The study area was divided into six planning regions, each representing areas with generally homogeneous elevation and mean annual precipitation (fig. 2). The siteselection goal was to have equal numbers of wadable sites draining small, medium, and large areas (less than 10, 10-100,

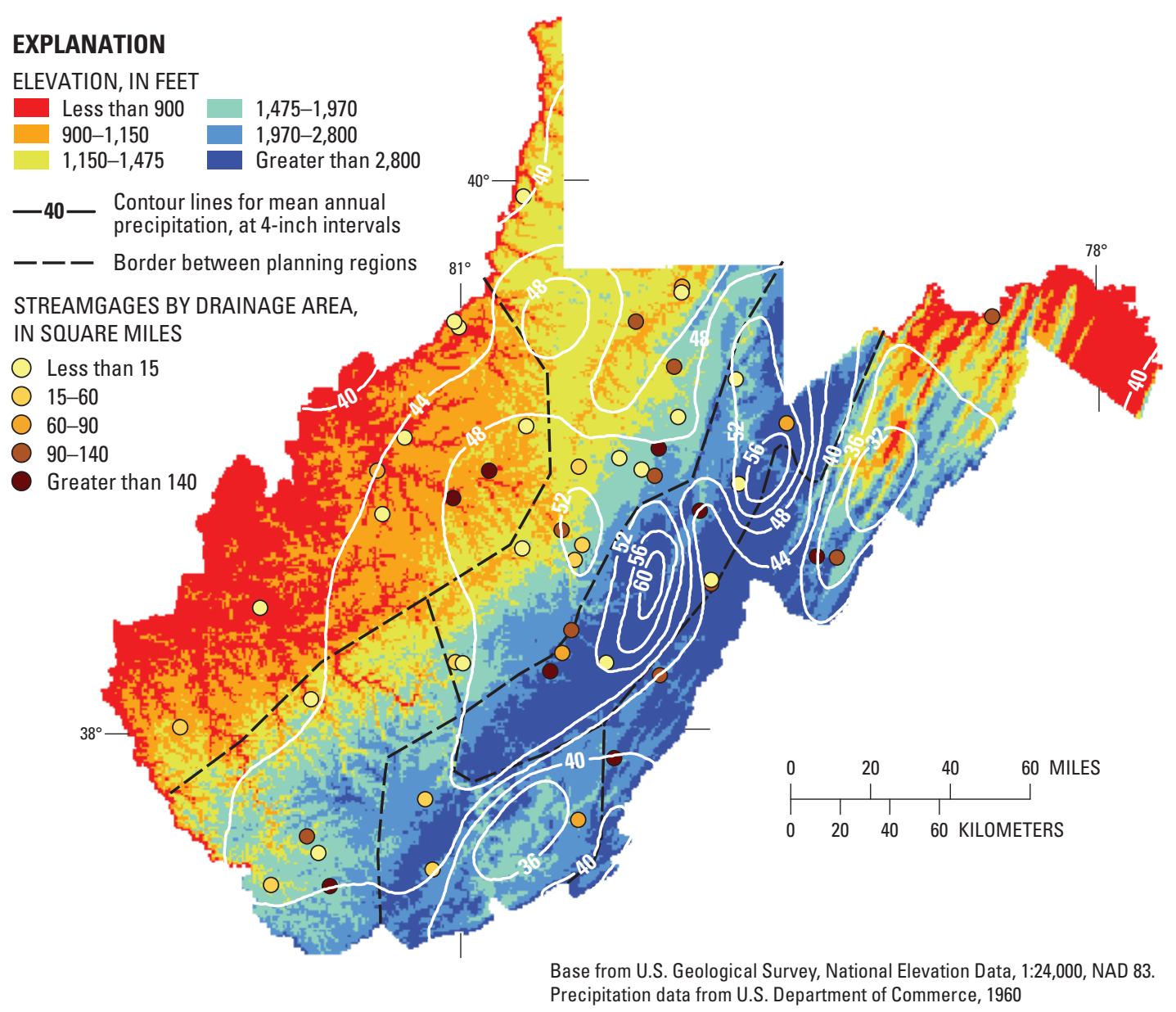

Figure 2. Regional curve planning regions, elevation, mean annual precipitation (shown in white contours), and recent streamgages on unregulated streams in West Virginia. 
and greater than $100 \mathrm{mi}^{2}$ ) from each planning region. Wadable sites were those where a detailed profile of the thalweg could be measured while wading; a drainage area of $240 \mathrm{mi}^{2}$ was adopted for planning, although several streams draining larger areas were reconnoitered and probably could have been surveyed during extreme low flows.

A competing goal for site selection was for all sites to have stable banks and readily identifiable bankfull features. Candidate reaches were excluded if banks were failing throughout most of their length, or if plausible bankfull features were not present. Gaged reaches were evaluated and included in the study if they met both these criteria.

Relatively few gaged reaches met these criteria, particularly when the streamgage was near a bridge or road. The majority of active streamgages were on non-wadable streams, although the majority of stream-restoration work is done on wadable streams. In addition, because available streamgages on wadable streams were disproportionately on the headwaters of major rivers, they were clustered in the central and eastern mountains of West Virginia (Messinger and Wiley, 2004).

Because not enough suitable gaged sites were available to build a network that could adequately represent the study area, ungaged sites were added. Two parts of the overall streamgaging record typically are used to develop regional curves: the high part of the stage-flow rating is used to determine bankfull flow, and the annual-peak series, based on 10 or more years of data, is used to confirm that bankfull flow is equivalent to a peak with an approximate recurrence interval of 1 to 2 years. Slope-area measurements, which define the high end of the stage-flow rating at the great majority of USGS streamgages, could be made for near-bankfull peaks during the 3 -year duration of the project.

Determining the recurrence interval of a peak approximately equivalent to bankfull flow would normally be more problematic than determining its flow and would preclude using ungaged sites in a regional-curve network. However, regional frequency relations for frequent, low-magnitude annual peaks had already been developed for three regions in West Virginia and were published with a series of regression equations for estimating flows of frequencies ranging from the 1.1-year flow through the 5-year flow (Wiley and others, 2002).

Streams that cross public land, including national parks, national forests, state parks, and wildlife management areas, were preferred in selecting ungaged reaches because these reaches were less likely to undergo adverse change in stream management and land use than were reaches on private land.

Not enough public lands were present in several planning regions to fill the gaps in the planning-region matrix. When suitable streams on public lands were not available, streams identified as candidate sites for antidegradation protection (West Virginia Department of Environmental Protection, 2005), draining appropriately sized areas, and in the desired locations, were assessed for inclusion in the study. The remaining reaches were identified in consultation with water or public-service professionals who were familiar with the area of interest. Only two suitable sites were identified in the Northern Panhandle after an extended reconnaissance effort, and this area remained underrepresented in the study (table 1; fig. 3).

\section{Channel Measurements}

Channels were surveyed with a total-station instrument. Second-order closure was achieved for all loops (Wolf and Ghilani, 2002). Longitudinal profiles were surveyed through a reach of at least 20 bankfull-channel widths. Reaches were comprised of two or more repeated sequences of riffles and pools. All profiles included thalwegs, water surface, plausible bankfull features, and high-water marks from a peak at or near apparent bankfull. Inner berms and point bars within the channel also were surveyed where they were present. Longitudinal stationing in the profiles was measured along the thalweg; a point in the thalweg was surveyed at the upstream and downstream bounds of the reach, at important changes in depth, and everywhere in the reach that other features were surveyed.

Cross sections were surveyed in riffles, preferably at the change in slope at the transition from pool to riffle. Two cross sections were surveyed at most gaged sites, although three were surveyed in reaches that included substantial changes in character. Cross sections were extended to an elevation of twice the maximum depth relative to the highest plausible bankfull feature. At some sites with wide forested or brushy flood plains (greater than 3 times bankfull width), the cross sections were surveyed for a minimum distance of 3 times bankfull width; the remaining distance to the edge of the flood plain was paced and its elevation was estimated.

At ungaged sites, cross sections were surveyed at major changes in the slope of the high-water profile for use in computing the slope-area measurement. At least four and as many as eight cross sections were surveyed at ungaged sites. At least two of the cross sections were surveyed according the same procedure used at gaged sites. The additional cross sections at ungaged sites were surveyed, at a minimum, to the higher of the high-water mark or the top of the bank.

\section{Bankfull Features}

For this study, the bankfull channel was defined as that part of the stream channel below the most distinct feature between the estimated elevations of the 1.1-year peak flow and the 2.0-year peak flow. Features used as indicators of the bankfull channel include, in order of preference and frequency used, rounded, vegetated, convex slope changes; bank substrate changes, particularly the edge of topsoil; sharp convex slope changes or those that showed other signs of instability; concave slope changes; and the elevation of an apparent flood plain. Each surveyed feature on a bank was described in written notes and assessed as to apparent quality (table 2 at end of report). 


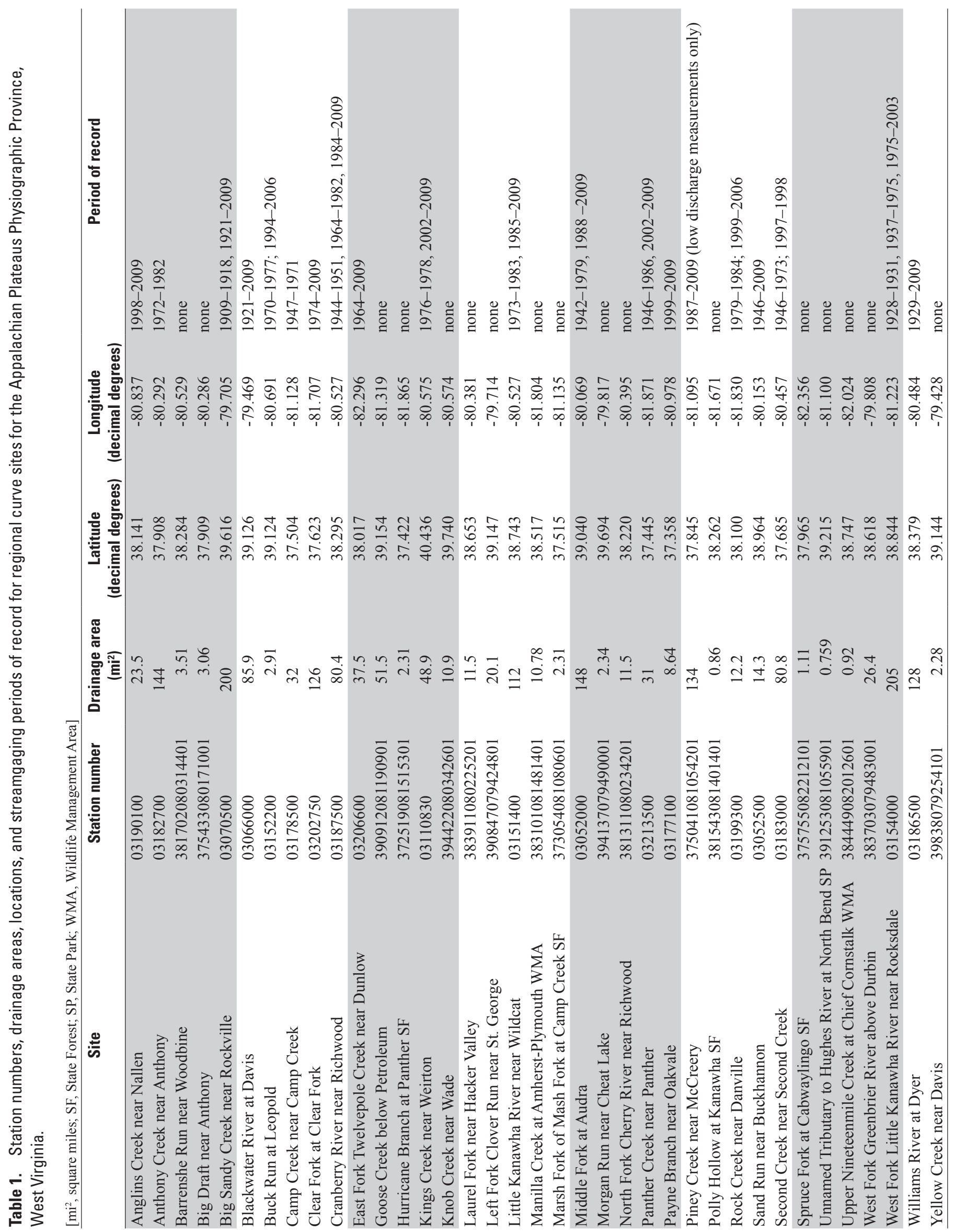




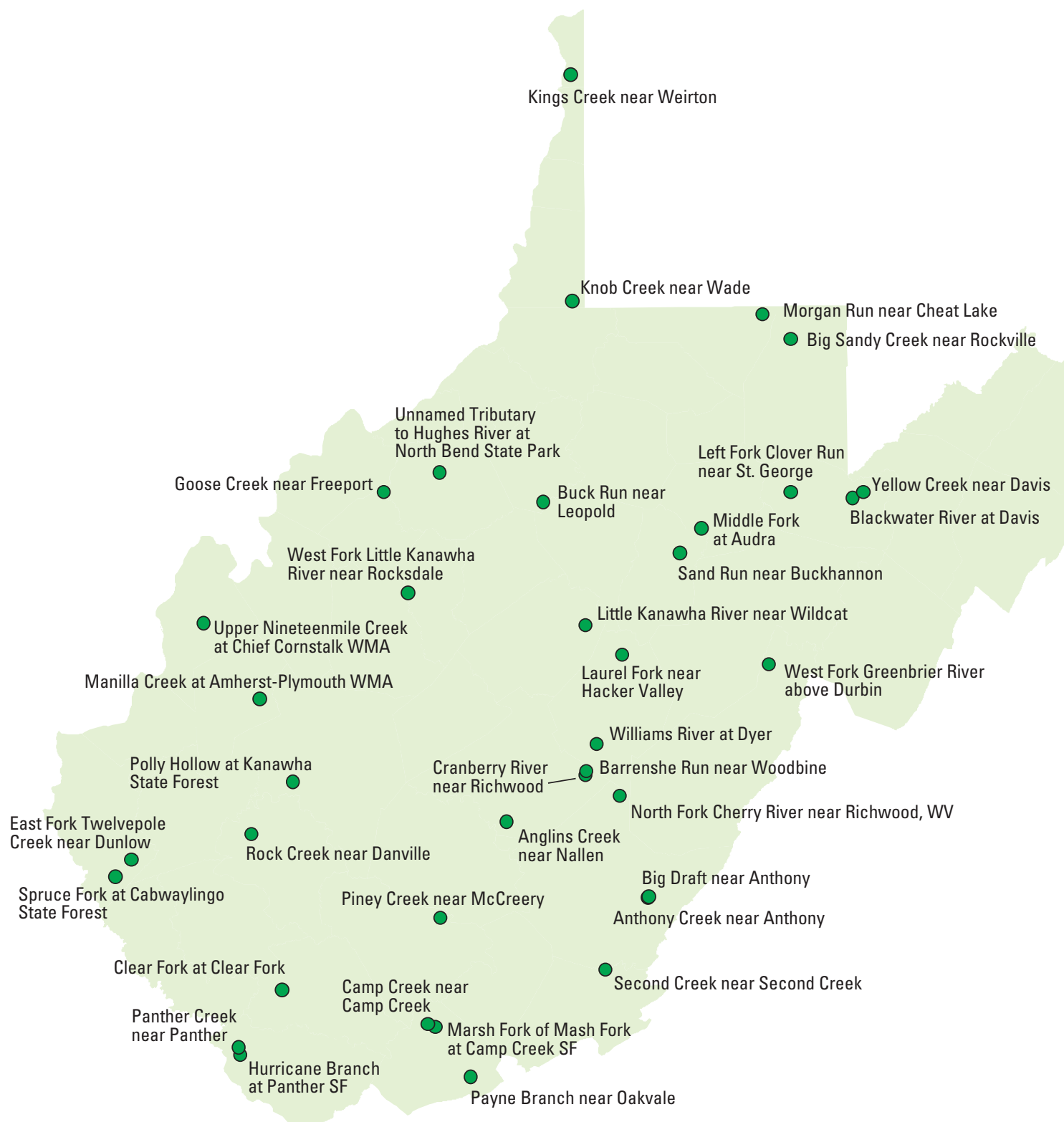

Base from U.S. Geological Survey, 2006, 1:2,000,000 digital files

Figure 3. Regional curve sites in the Appalachian Plateaus Physiographic Province, West Virginia. 
Extra consideration was given to features when more than one was present at the same spot; for example, combinations of a distinct rounded convex slope change from the bank to the flood plain with mature plant growth, or a convex slope change at the edge of topsoil were regarded as especially good bankfull indicators.

In most reaches assessed in this study, there were one or more reaches with more than one feature on the bank at the same longitudinal station that could plausibly be regarded as the bankfull feature. In these cases, all the plausible bankfull features at the station of interest were surveyed, and the final determination of which to use was made with the profile plot used as a supplement to field notes.

\section{High-Water-Mark Profiles}

At all sites, a profile of high-water marks was flagged for a peak greater than half of apparent average bankfull depth, but inside the bank. At ungaged sites, the high-water marks were used to measure peak flow by the slope-area method (Dalrymple and Benson, 1967). Slope-area measurements were computed using the Slope-Area Computation program (Fulford, 1994) and checked using the HEC-RAS model (U.S. Army Corps of Engineers, 2009). At gaged sites, flow was determined for the flagged peak using the station rating or the stage-flow relation defined by current-meter and indirectflow measurements (Rantz and others, 1982). The peak flow measured at the streamgage was used to verify roughness in the reach.

High-water marks were flagged as soon as practical after flow peaked or, in two cases, the high-water surface was flagged while still at near-bankfull flow (table 3). If distinct, continuous high-water-marks were present, high-water marks were flagged at minimum longitudinal distances equivalent to estimated bankfull width, and closer together in parts of the reach where slope appeared to change. If only a few highwater marks were distinct, all the distinct marks were flagged. The date and the type and quality of the mark were written on a strip of plastic survey flagging, then pinned to the mark with a nail. Once flagged, sites were surveyed when convenient.

The most commonly used high-water marks were wash lines in leaf litter on the bank. Other fairly common highwater marks were deposits of ground-up tree leaves, hemlock or spruce needles, and depending on season, seed lines. Mud stains on plants or fallen leaves were generally indistinct and used at only two or three sites, but at those sites, they were the predominant high-water mark. Roughness values for the ungaged sites were determined by comparing sections of stream channel to sections of stream channel from gaged sites with verified roughness values and to published photographs of reaches with verified roughness values (Barnes, 1967), then were compared with roughness values computed using two different formulas (Jarrett, 1984; Limerinos, 1970). Roughness values exceeding those calculated from the formulas were used when field notes and photographs supported the higher values, for example, when a cross section was affected by backwater from a log or boulder downstream.

The high-water-mark profiles were used to supplement, or at most sites, replace the use of estimated channel dimensions from flow measurements at streamgages as a means of choosing among plausible bankfull features at the same longitudinal station. Instead of referring to estimated bankfull elevations and dimensions derived from flow measurements, the elevation of a plausible bankfull feature was compared to that of the high-water-mark profile, while considering the frequency of the peak. At gaged sites, the magnitude and frequency of the peak that left the marks was known. The frequency of peak flow at ungaged sites was estimated by comparison to flow at index streamgages, taking into account the differences in storm precipitation among basins.

For example, at Cranberry River near Richwood, flow peaked on the night of November 16, 2006, at 3,010 ft $3 / \mathrm{s}$, just less than the 1.2-year flow for the site and about the 2.0-year flow for the Southern Region (Wiley and others, 2002). The profile was flagged the next morning. Nine high-water marks, all wash lines, were flagged; seven were good, and two were fair. Identification of bankfull features was relatively simple at this site. All the bankfull features surveyed were points where a convex slope change from the narrow flood plain to the bank coincided with the edge of the topsoil. Because the bed and banks were dominated by large boulders (D84 (84th percentile of particle size $)=2.12 \mathrm{ft}$ at one cross section and greater than $6.00 \mathrm{ft}$ at the other), the bankfull features were not continuous for extended lengths in the reach, and in fact, identifiable bankfull features were not present in segments of the profile where they would have been useful to measure. Through most of the reach, flow peaked at or just above bankfull features, although the bankfull features in the riffles were lower relative to the high-water marks than were the features in the pools (fig. 4). At XS2, the upstream cross section, the primary bankfull feature was the edge of topsoil, which collected among jagged, poorly eroded rocks, coincident with a convex slope change on the left bank, and it was rated as fair. An additional bankfull feature on the right bank was only $0.17 \mathrm{ft}$ higher and was described as a rounded convex slope change formed of topsoil and anchored by tree and mountain laurel roots. At XS1, the downstream cross section, the primary bankfull feature, on the left bank, was a lumpy, convex slope change from a depositional shelf to the bank that coincided with the edge of topsoil and was rated as good. The bankfull feature on the right bank also was surveyed; it was only $0.36 \mathrm{ft}$ lower and was a rounded, distinct convex slope change from a gently sloping section of bank to a steeper section of bank, coincided with the edge of topsoil, and was covered with well-established moss. Bankfull flow was calculated to be $1,380 \mathrm{ft}^{3} / \mathrm{s}$ at XS2, the upstream cross section, and 2,070 $\mathrm{ft}^{3} / \mathrm{s}$ at XS1, the downstream cross section, for an average of $1,720 \mathrm{ft}^{3} / \mathrm{s}$ for the reach. Although the calculated bankfull flow was less than expected and inconsistent between the cross sections, the 


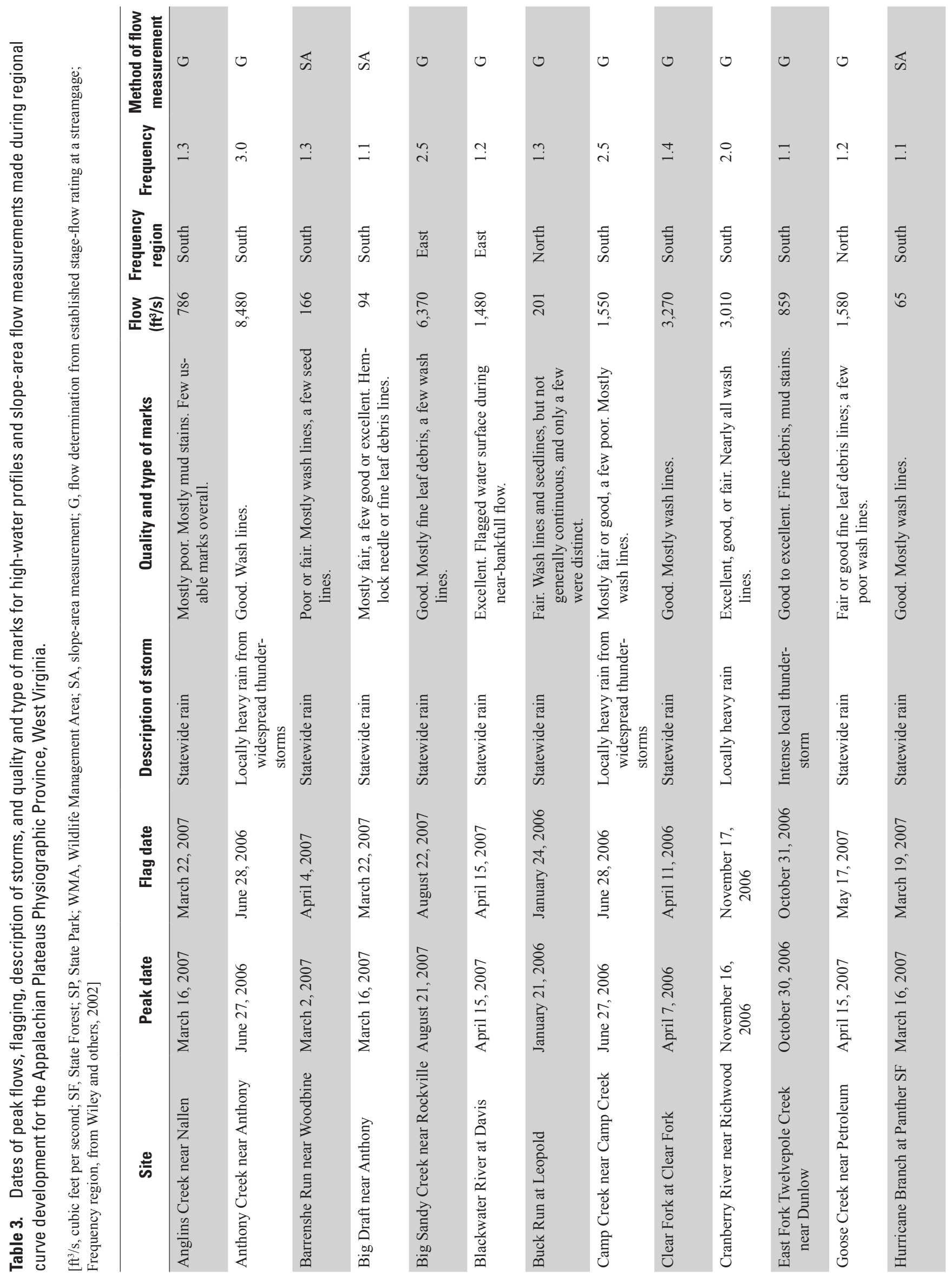




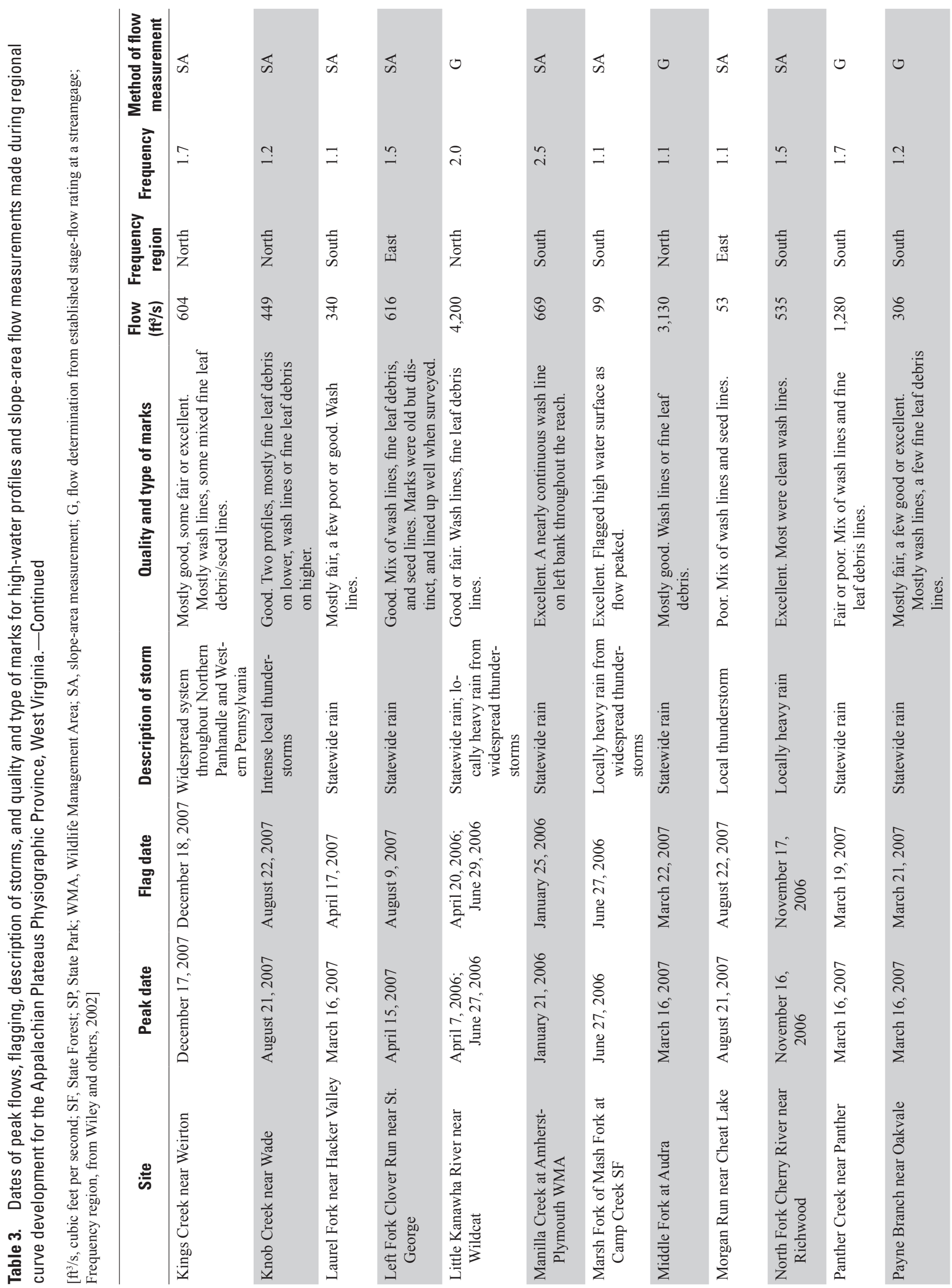




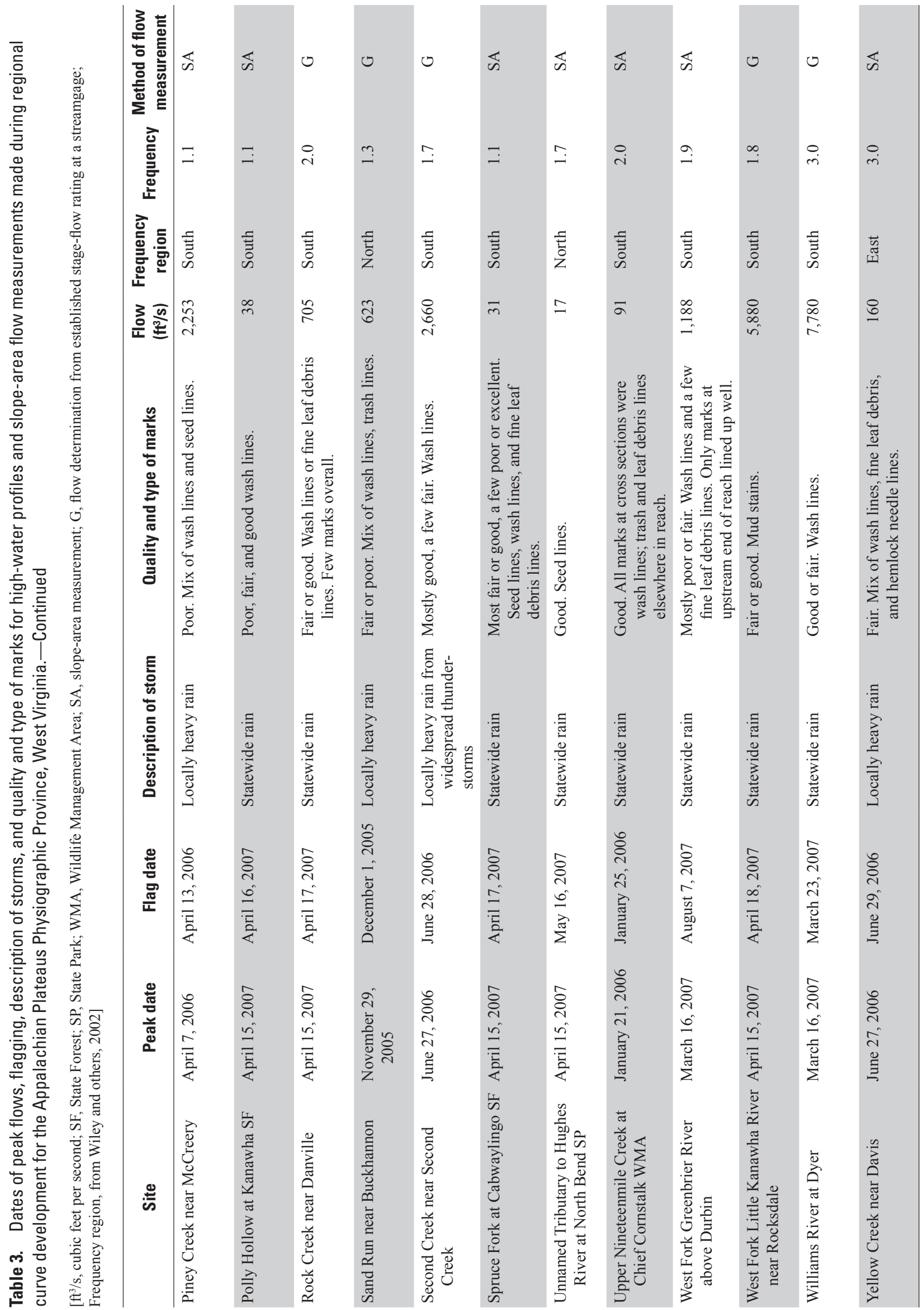


features at the cross sections were good, consistent on both banks, and comparable to the high-water-mark profile, and so were used for computing bankfull dimensions.

At another site, West Fork Little Kanawha River near Rocksdale, on April 15, 2007, flow peaked at 5,880 ft $\mathrm{ft}^{3} \mathrm{~s}$, corresponding to the 1.8-year flow for the Southern Region of West Virginia or the 1.4-year flow calculated for that site (Wiley and others, 2002; table 1). The peak was flagged 2 days later, and the marks, mostly mud stains on grass, were generally fair, although a few were good. In contrast to Cranberry River near Richwood, identifying bankfull features at West Fork Little Kanawha River near Rocksdale was problematic. The channel was incised; through most of the reach, the banks were complex, and several depositional features, any of which might plausibly have been bankfull features, were present (fig. 4; table 2). The most distinct bankfull features were in the pools, which made up most of the reach, but these features were not continuous into the riffles. Throughout most of the reach, the top of the bank was noted to be an exceptionally distinct convex slope change from a wide, generally flat wooded area to a steep bank; this feature was judged to be a terrace because it was several feet above the high-water-mark profile. At both cross sections, several plausible bankfull features were present. At the upstream cross section, four features were surveyed and described, but three of them were judged to be poor. The most distinct of them, a convex slope change on the left bank, anchored by tree roots and rated as fair, was chosen as the bankfull feature to determine cross-sectional dimensions, although it was higher than the trend line for bankfull features through the reach. At the downstream cross section, three plausible bankfull features were surveyed and described. Two of the three were judged to be poor; both were abrupt convex slope changes. The feature which best fit the trendline of bankfull features was at the top of a recent slump and was judged to be poor. The feature chosen to determine cross-sectional dimensions was at the top of the left bank-a sharp convex slope change from flood plain to a steeply sloping bank. Established weed growth was noted, and the feature was judged to be fair.

Bankfull features were compared to high-water-mark profiles at all sites, even if, as at East Fork Twelvepole Creek near Dunlow (fig. 4, table 3), the high-water-mark profile was left by a storm peak that was substantially lower than expected for bankfull flow. The high-water-mark profile was used in generally the same way at ungaged sites. At Manilla Creek near Poca, for instance, the top of the bank was judged as the apparent bankfull feature during site reconnaissance. Flow peaked at $669 \mathrm{ft}^{3} / \mathrm{s}$ on January 21, 2006, which corresponded to about the 2.5-year flow for West Virginia's Southern Region (Wiley and others, 2002). The feature at the top of the bank was at the high-water-mark profile through the upstream part of the reach but about a foot higher than the high-water-mark profile for the downstream part of the reach (fig. 5). That feature was judged to be a terrace, and a different, lower set of features identified in reconnaissance as the inner berm was chosen as the bankfull feature. At Laurel Fork near Hacker Valley, at least two plausible bankfull features were present through most of the reach. The high-water-mark profile was left by a peak of $340 \mathrm{ft}^{3} / \mathrm{s}$, about the 1.1-year flow for the Southern Region of West Virginia (Wiley and others, 2002), and the peak was near the lower of the two features (fig. 5). At sites like Big Draft near Anthony, where, similar to Cranberry River near Richwood, the flagged peak was very near bankfull and only one set of plausible features was present (fig. 5), identification of bankfull features would probably have been straightforward using any procedure.

\section{Relation of Profiles to Streamgages}

In addition to this difference in confirming the identification of bankfull features, the other major departure from methods described by Leopold (1994) and Rosgen (1996) was a difference in the way data collected at the streamgage were used to determine bankfull flow. Typically, a profile of bankfull features is surveyed upstream and downstream from a streamgage, a line is fit through a plot of the profile, and the elevation of the line at the streamgage is compared to the stage-flow rating. However, this approach can give inaccurate results under common, predictable conditions.

First, the use of a fitted line assumes that bankfull elevation falls through the reach in a more or less linear manner. Although this is true in some streams - particularly lowgradient, meandering streams - a common pattern in rifflepool streams is for profiles to be stepped, with relatively little fall in pools and most of the fall in riffles (fig. 6; Leopold, 1994). Plots of bankfull features are nearly parallel to plots of high-water marks. Steps are less pronounced at bankfull flow than at lower flows but are still clear. High-water-mark profiles show the stepped pattern more clearly than do bankfull profiles because, in most streams, bankfull features form at a greater range of elevations through a reach than do marks left by a single peak. In addition, bankfull features are more difficult to identify precisely than high-water marks left by bankfull flow. (Exceptions might include high-water marks in steep streams with turbulent flow and a substrate of mobile boulders, where standing waves move through the reach as the boulders they form over move downstream.)

If all the pools and riffles in a reach had approximately the same slopes and lengths, then the principal source of error in profile-rating relations in a stepped profile with correctly identified features would be the position of a streamgage on its pool relative to the positions within the reach of the features selected for identification. If features are identified at equal intervals through a stepped reach, a line fit through them will pass through features near the center of pools and riffles. Features at the upstream end of a pool will fall below the line, and features near the downstream end of a pool will fall above the line. This idea is confirmed by field observations of high-water marks left by a pair of near-bankfull peak flows. The Middle Fork at Audra streamgage is near the upstream end of its pool, and an observed peak gage height confirmed by a good highwater mark at the streamgage structure was $0.91 \mathrm{ft}$ below a trendline fit through the profile of high-water marks (fig. 6a). 


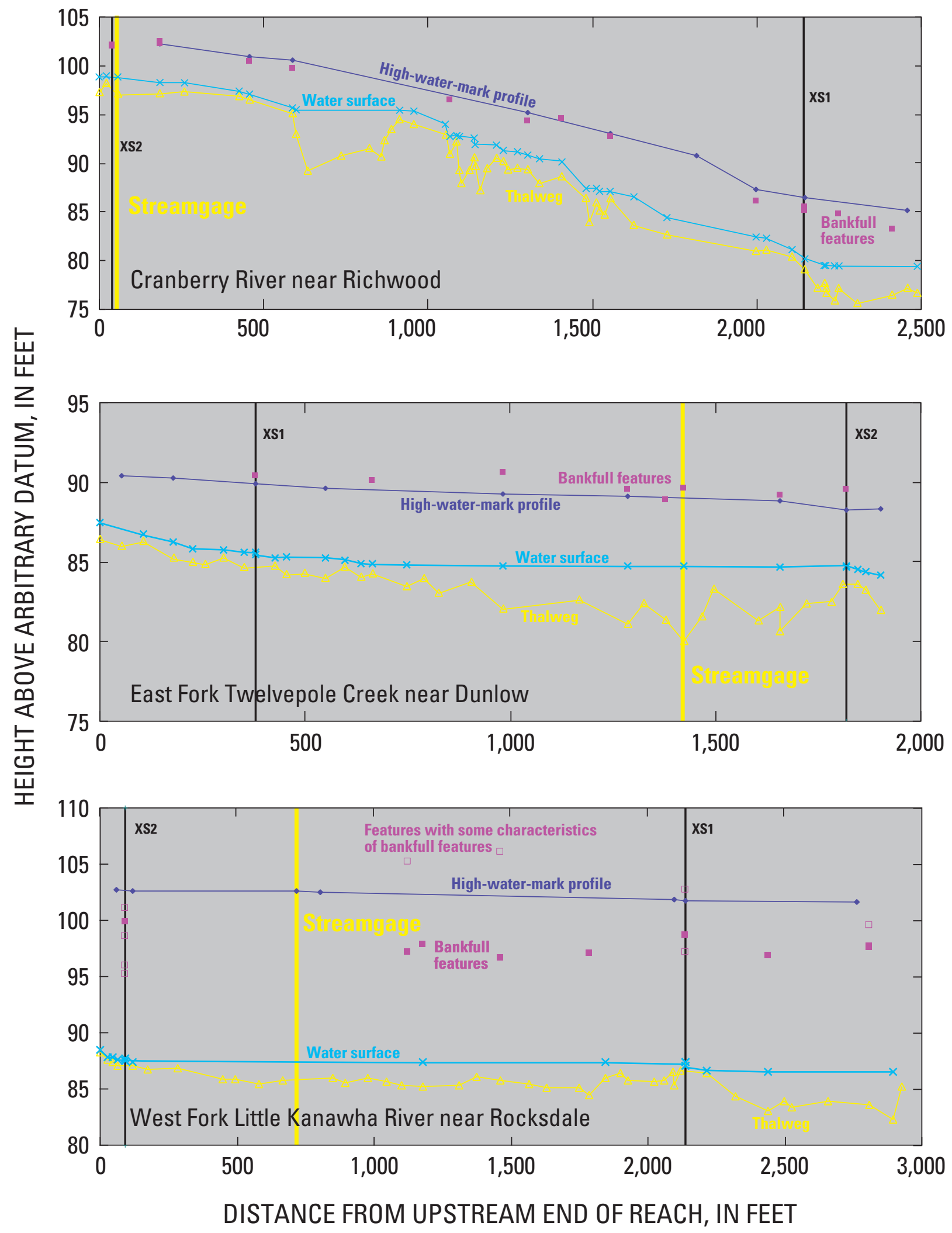

Figure 4. Profiles of selected gaged stream channels in the Appalachian Plateaus Physiographic Province of West Virginia. 


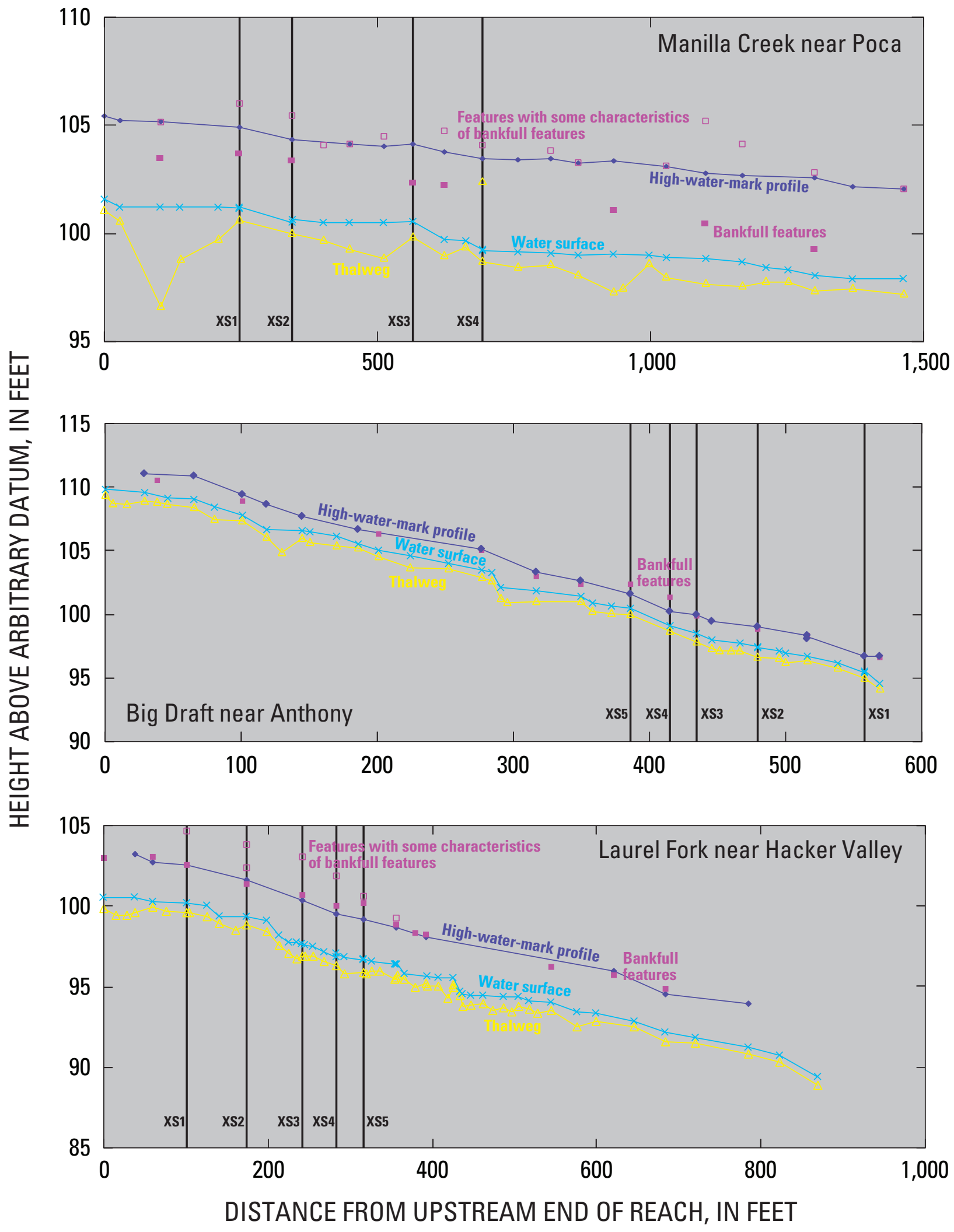

Figure 5. Profiles of selected ungaged stream channels in the Appalachian Plateaus Physiographic Province of West Virginia. 


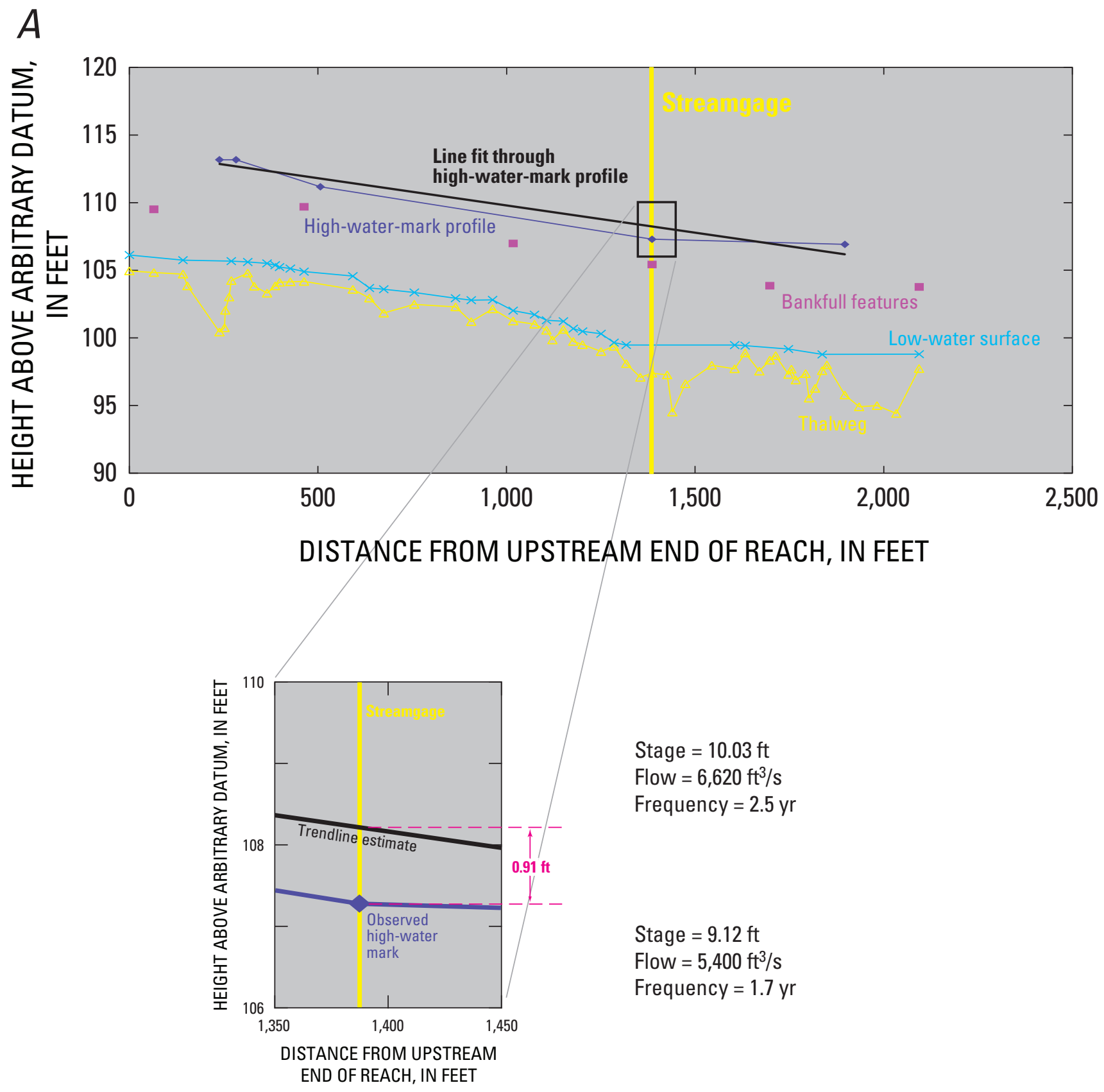

Figure 6. Selected profiles of high-water marks from near-bankfull peaks, bankfull features, low-water surface, and thalwegs for reaches at streamgages at $(A)$ Middle Fork at Audra and $(B)$ Panther Creek near Panther, West Virginia. High-water marks, bankfull features, and low-water surface all have slope changes at approximately the same location. Differences in stage, flow, and frequency are shown between water-surface elevation of a measured high-water mark and a line fit through the high-water-mark profile. 


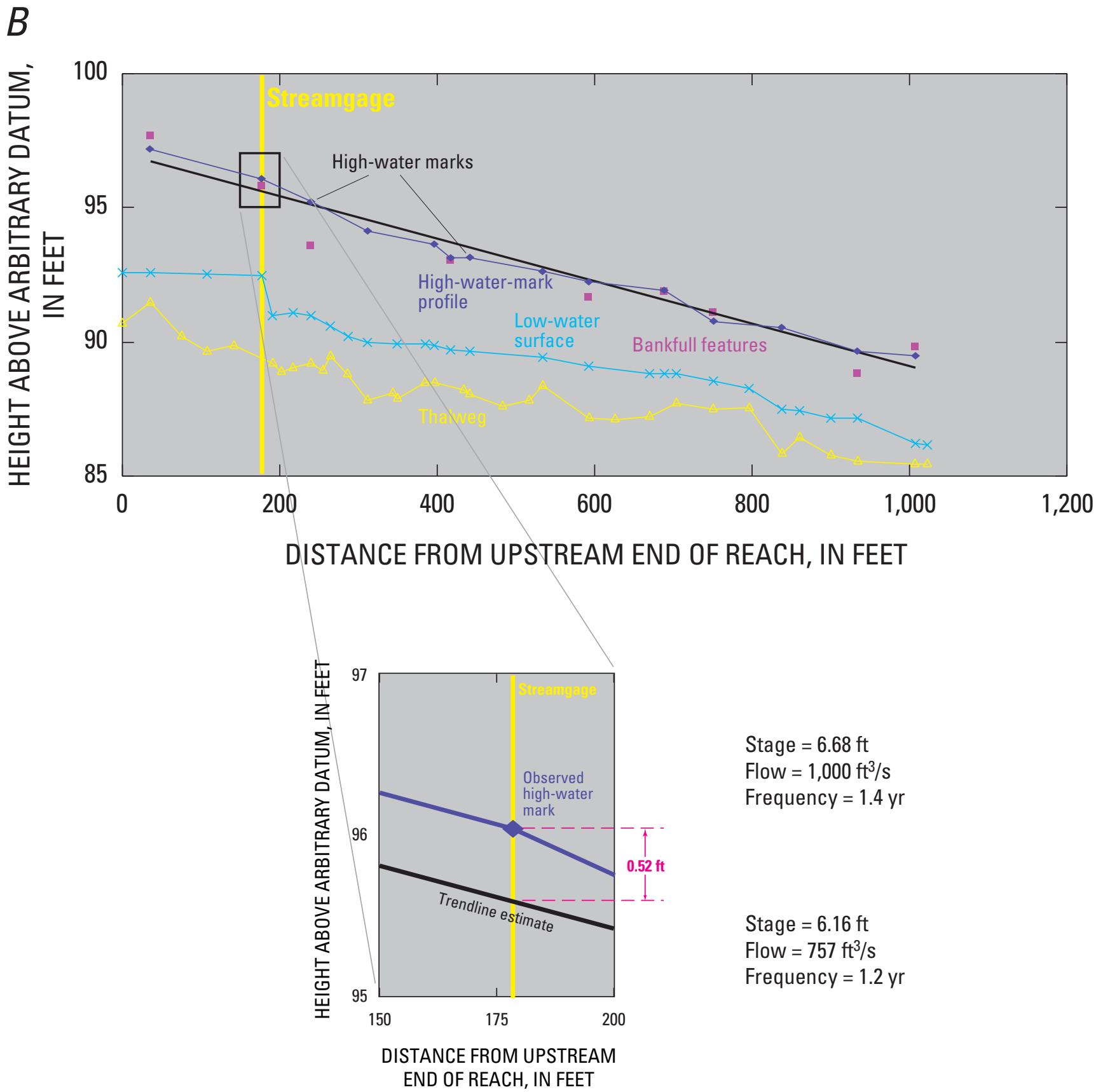

Figure 6. Selected profiles of high-water marks from near-bankfull peaks, bankfull features, low-water surface, and thalwegs for reaches at streamgages at $(A)$ Middle Fork at Audra and $(B)$ Panther Creek near Panther, West Virginia. High-water marks, bankfull features, and low-water surface all have slope changes at approximately the same location. Differences in stage, flow, and frequency are shown between water-surface elevation of a measured high-water mark and a line fit through the high-water-mark profile. - Continued 
The Panther Creek at Panther streamgage is at the downstream end of its pool, and an observed peak gage height confirmed by a good high-water mark at the streamgage structure was $0.52 \mathrm{ft}$ above a trendline fit through the profile of high-water marks (fig. 6b). Errors of these magnitudes in the near-bankfull part of ratings correspond to large errors in flow estimates. At Middle Fork at Audra, a $0.91 \mathrm{ft}$ difference in gage height (between an estimate of $10.03 \mathrm{ft}$ and an observation of $9.12 \mathrm{ft}$ ) corresponds to an overestimation of peak flow of $1,220 \mathrm{ft}^{3} / \mathrm{s}$ (estimating $6,620 \mathrm{ft}^{3} / \mathrm{s}$ when the measured flow was $5,400 \mathrm{ft}^{3} / \mathrm{s}$, or 23 percent). The frequency for the estimated peak is about 2.5 years, but 1.7 years for the measured peak. At Panther Creek at Panther, a $0.52 \mathrm{ft}$ difference in gage height (between an estimate of $6.16 \mathrm{ft}$ and an observation of $6.68 \mathrm{ft}$ ) corresponds to an underestimation of peak flow of $243 \mathrm{ft}^{3} / \mathrm{s}$ (estimating $757 \mathrm{ft}^{3} / \mathrm{s}$ when the measured flow was $1,000 \mathrm{ft}^{3} / \mathrm{s}$, or about 24 percent). However, the frequency of this estimated peak is about 1.2 years and, for the measured peak, 1.4 years.

If features are identified primarily at the same position in pools and riffles as the streamgage is located, then a line fit through them will accurately reflect the profile elevation at the streamgage. If more features are identified near the upstream ends of pools and riffles than near the downstream ends, then the profile will be shifted artificially upward, and the profile will be shifted artificially downward if disproportionate numbers of features are identified near the downstream ends of pools and riffles.

In the field, the investigator may have little choice as to where to identify features along a profile, especially in problematic reaches with few identifiable features or features that are not continuous through the reach. Selecting additional, poorly defined features because they are at a position in the profile where they would be convenient is unlikely to increase the accuracy of estimated flow.

Another major source of variation in the relation between the profile and rating is the effect of bridges and culverts on ratings. Streamgages are built where a stable feature controls the stage-flow rating throughout the range of stages. The highwater control is typically a constriction in the channel, and a box culvert or bridge with piers at mid-channel often makes an ideal high-water control. Furthermore, streamgages are deliberately installed near roads because easy access not only saves effort and money but improves the quality of the flow record by making it faster and easier to reach the site to measure flow and service instruments. If a streamgage can be built where the stream can be measured from a bridge, then the expense and risk of building a cableway is spared. Often, streamgages are attached to bridges.

Locating streamgages upstream from bridges that control water-surface elevation puts the streamgage in backwater at bankfull, or lower, flow. This means that depth is artificially greater at the streamgage than elsewhere in the reach. Bridges also may cause streambeds to scour and banks to erode, so banks near bridges and culverts are frequently armored with riprap or gabions (fig. 7). In these cases, natural bankfull features at the streamgage no longer exist, the channel at the streamgage may be unrepresentative of the rest of the reach, and bankfull elevations from elsewhere in the reach are unrelated to elevations at the streamgage.

At gaged sites, slope and roughness values were calculated from the high-water-mark profile using the flow measured at the streamgage. At ungaged sites, the slope and roughness values determined in the slope-area flow measurement were used to calculate bankfull flow. For all reaches, roughness values were adjusted for differences in depth between the high-water-mark and the bankfull profile before computing bankfull flow. The adjustment for depth was made by calculating a theoretical roughness value for each cross section in the high-water-mark and bankfull profiles using the formula of Jarrett (1984). The ratio of these two roughness values was computed, then multiplied by the roughness values determined for the high-water-mark profiles to obtain bankfull roughness. These bankfull roughness values were used in Manning's equation to compute bankfull flow for each cross section. The bankfull flows were then averaged for the reach.

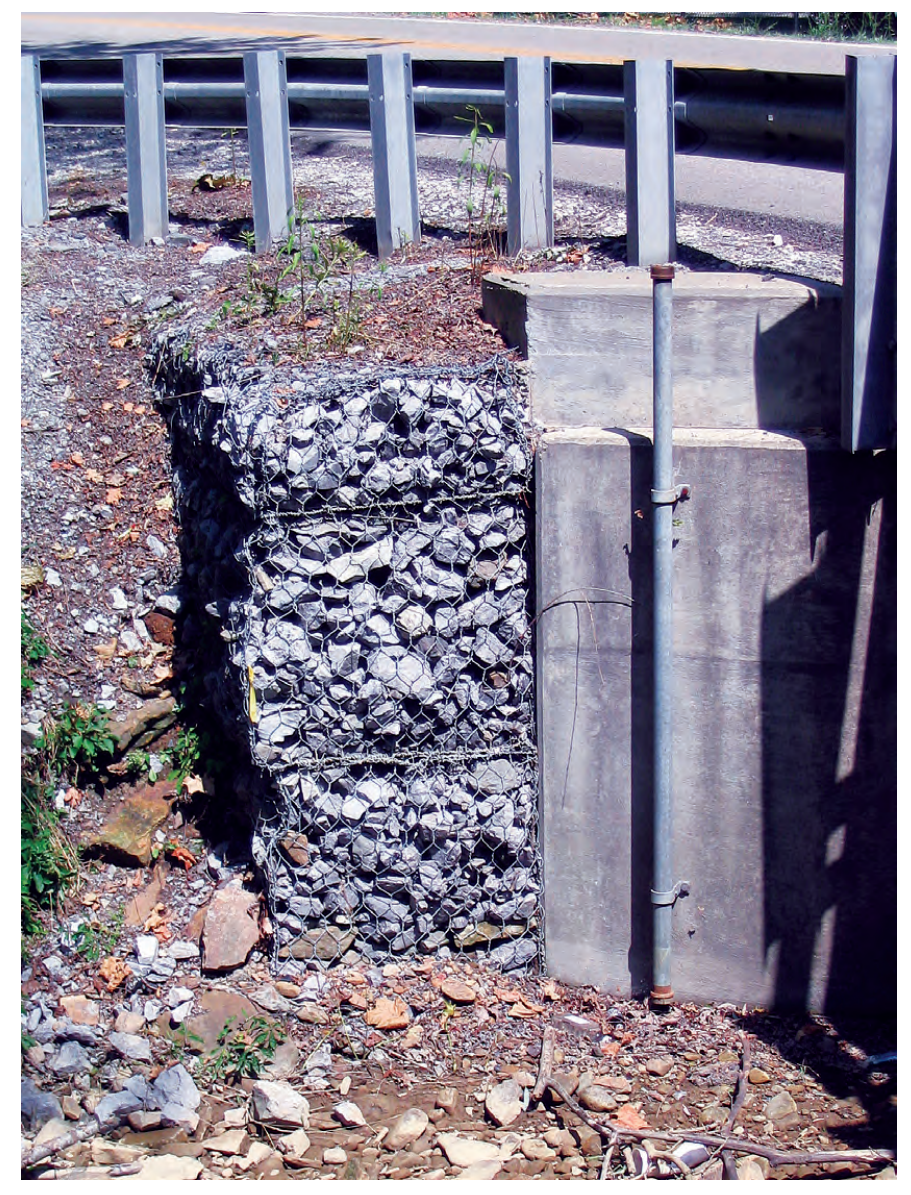

Figure 7. Crest-stage streamgage at Marsh Fork at Maben, West Virginia. 


\section{Bankfull Flow Frequencies}

Regional peak-flow magnitudes with frequencies between 1.1 and 3.0 years had been previously computed for West Virginia (Wiley and others, 2002), which was split into three regions, the Northern, Southern, and Eastern Regions, on the basis of geographic analysis of regression residuals. The Northern and Southern Regions are entirely within the study area for this project, as is part of the Eastern Region.

The regression equations were developed with the goal of providing information to be used in NCD and related studies. The equations for each of the regions are significantly different $(p<0.05$; Wiley and others, 2002) from those of the other two regions. However, for the purposes of this study, new regression equations were developed by combining annual-peak flow data from all the streamgages within the Appalachian Plateaus on streams draining less than $240 \mathrm{mi}^{2}$. Regional regression equations from the previous study were not used because of four reasons. First, among the smaller streams, a group of short-term streamgages operated approximately from 1966 through 1977, a period that included a major drought, are clustered closely together on a plot of 1.5 -year annual peak flow as a function of drainage area and are among the stations with the lowest 1.5-year annual peak flow (fig. 8). Although stations in all three regions are in this cluster, there are fewer long-term streamgages in the Southern Region than in the other regions, so the streamgages from this cluster had an exaggerated effect on the Southern Region's regression equation. Second, the regional equations appear to have been strongly influenced by larger streams, which both accounted for most of the available data and were much more likely to have long periods of record and, therefore, to have data collected through wet and dry climatic periods. Third, $\mathrm{R}^{2}$ and standard error for the regional equations were only slightly different than for the aggregated equation. Fourth, and most important, geographic analysis of bankfull characteristics, as discussed later in this report, showed no regional difference within the Appalachian Plateaus, and a comparison of bankfull characteristics from a single region to a single peak-flow frequency relation was simpler and more relevant.

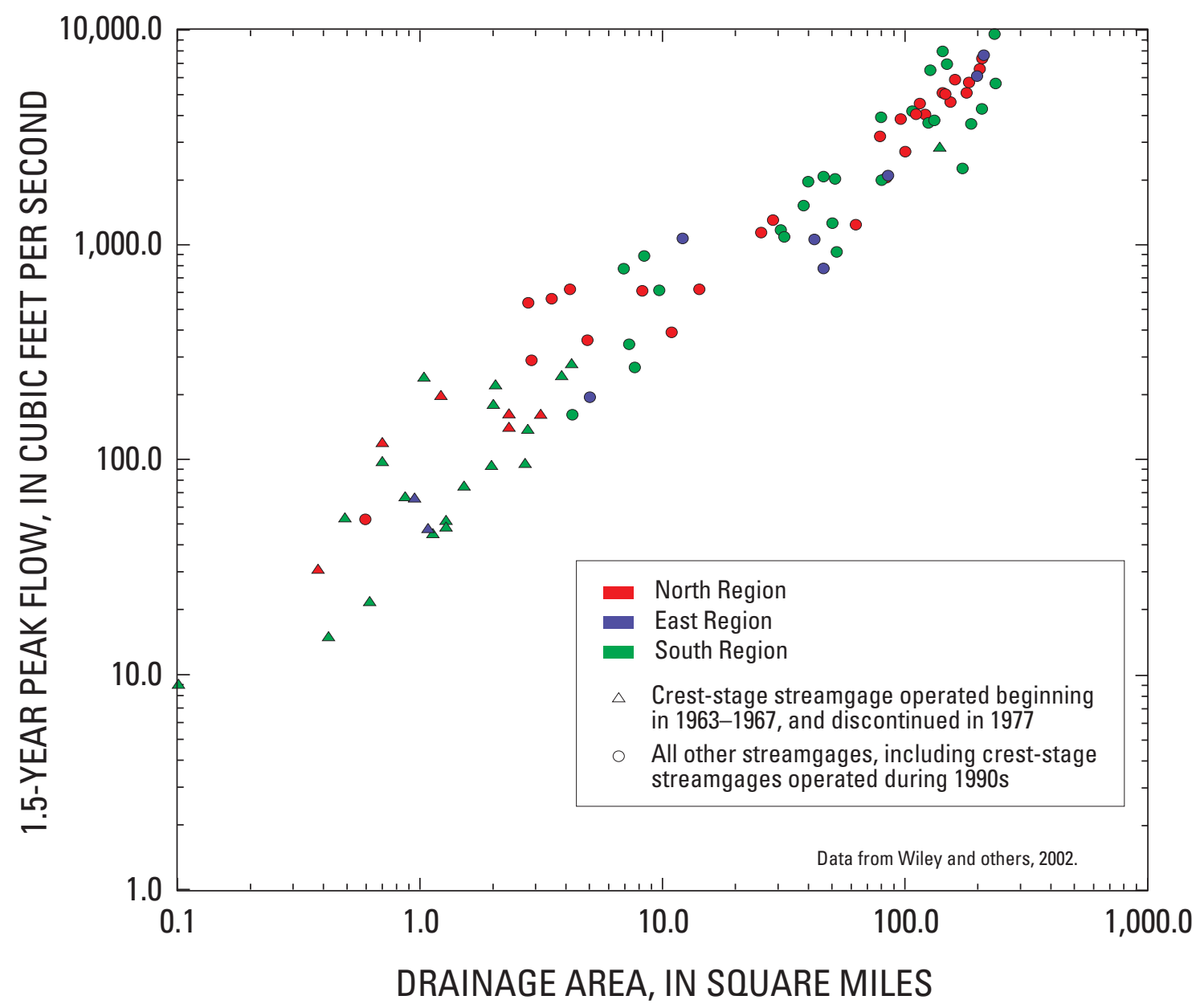

Figure 8. 1.5-year peak flow at streamgages draining less than 240 square miles in the Appalachian Plateaus Physiographic Province, West Virginia, by region and end year of systematic record. 


\section{Bankfull Characteristics and Regional Curves}

Bankfull flow and dimensions were determined from cross sections surveyed at riffles (table 4 at end of report). A single set of regional curves was developed, on the basis of simple linear regression of bankfull characteristics as a function of drainage area. All the bankfull characteristics that were determined were strongly correlated with drainage area. Enough of the variation was explained by that single independent variable that exploring finer regional variation, or effects of other basin characteristics, was unlikely to provide meaningful results.

\section{Flow}

At the 10 active streamgages with more than 10 years of record, bankfull flows ranged from less than the 1.1-year flow to greater than the 2.0-year flow. The other streamgages that were available were one continuous streamgage with less than 10 years of data; crest-stage streamgages, which had relatively short periods of record; and discontinued streamgages. Furthermore, the periods of record were not concurrent among short-term stations. These factors complicate direct comparison of peak-flow frequencies among the sites, so an approach was adopted of comparing bankfull flow to peak flows of specific frequencies from all the streamgages in the study area in the comparable size range.
Drainage area accounted for slightly more of the variation for bankfull flows $\left(\mathrm{R}^{2}=0.9592\right.$; Standard error $(\mathrm{SE})=$ 13.7 percent) than it did for the variation in 1.5 -year peak flows measured at streamgages on wadable streams in the Appalachian Plateaus $\left(\mathrm{R}^{2}=0.9326 ; \mathrm{SE}=19.5\right.$ percent; table 5; figs. 9, 10). The regression lines for flows at the 1.2-, 1.3-, 1.4-, 1.5-, 1.6-, and 1.7-year recurrence intervals, computed for streamgages on wadable streams in the Appalachian Plateaus (fig. 11), all fell within the 99-percent confidence interval of the regression line for bankfull flow (for legibility, the lines for the 1.3- and 1.6-year flows are not depicted on fig. 11). The closest match to the regression line for bankfull flows is the line for the 1.4-year peak flow for the Appalachian Plateaus.

\section{Dimensions}

Bankfull area strongly $\left(\mathrm{R}^{2}=0.9768 ; \mathrm{SE}=8.5\right.$ percent $)$ and significantly $(\mathrm{P}<0.001)$ correlated with drainage area (table 4; fig. 12). An $\mathrm{R}^{2}$ value of 0.9768 for bankfull area indicates that little additional variation can be explained by subdividing the study area by region, stream type, geology, or other characteristics. West Fork Little Kanawha River near Rocksdale, the site with the greatest positive residual value for bankfull area, was initially selected as a candidate site for a possible subregion, the Western Foothills. However, the banks at this site were among the least stable, and bankfull features at this site were among the least distinct included in the study, both of which increase the possibility that bankfull dimensions for this site might be wrong. Because the other sites in this

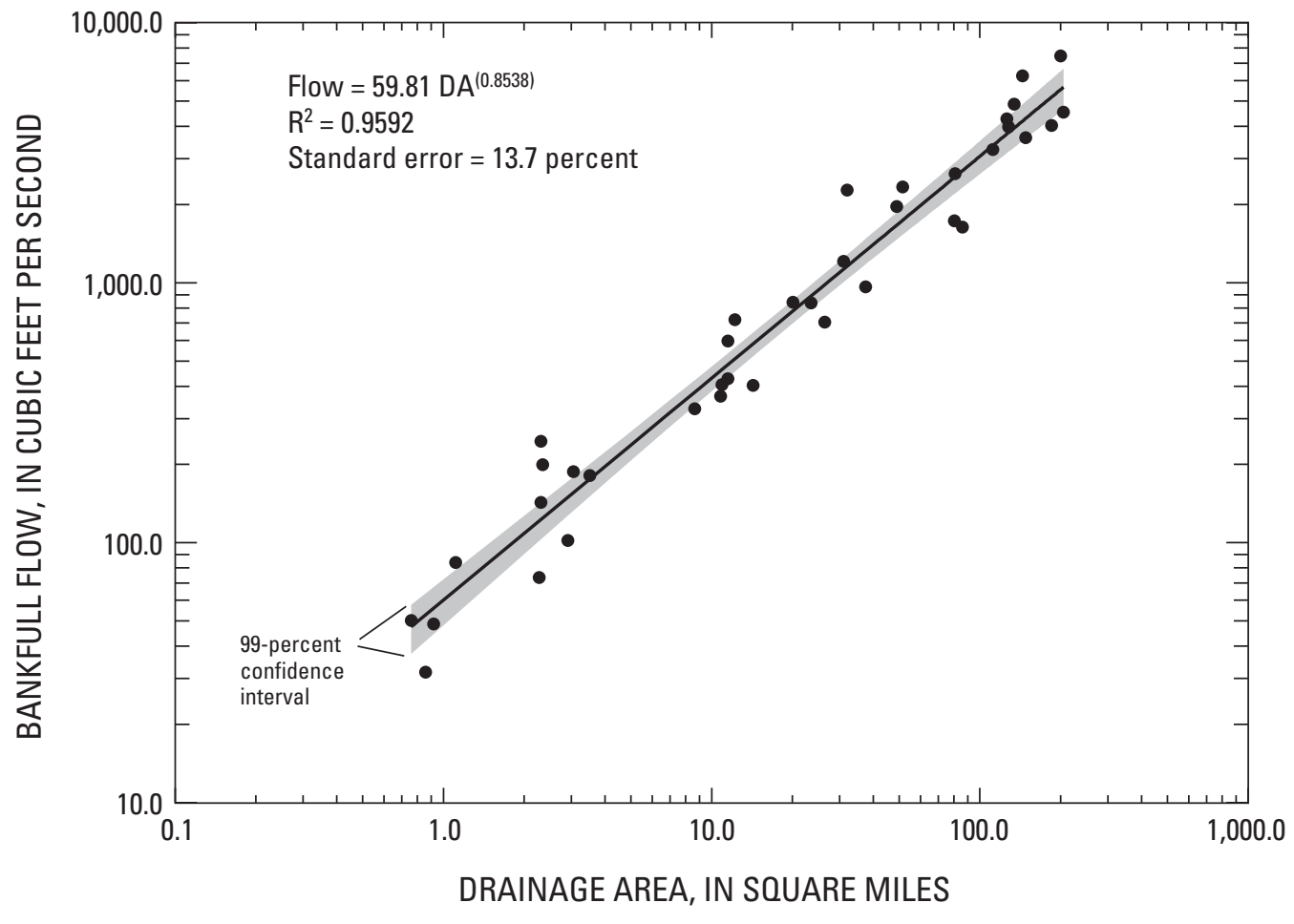

Figure 9. Relation between bankfull flow and drainage area for selected wadable streams in the Appalachian Plateaus Physiographic Province in West Virginia. 

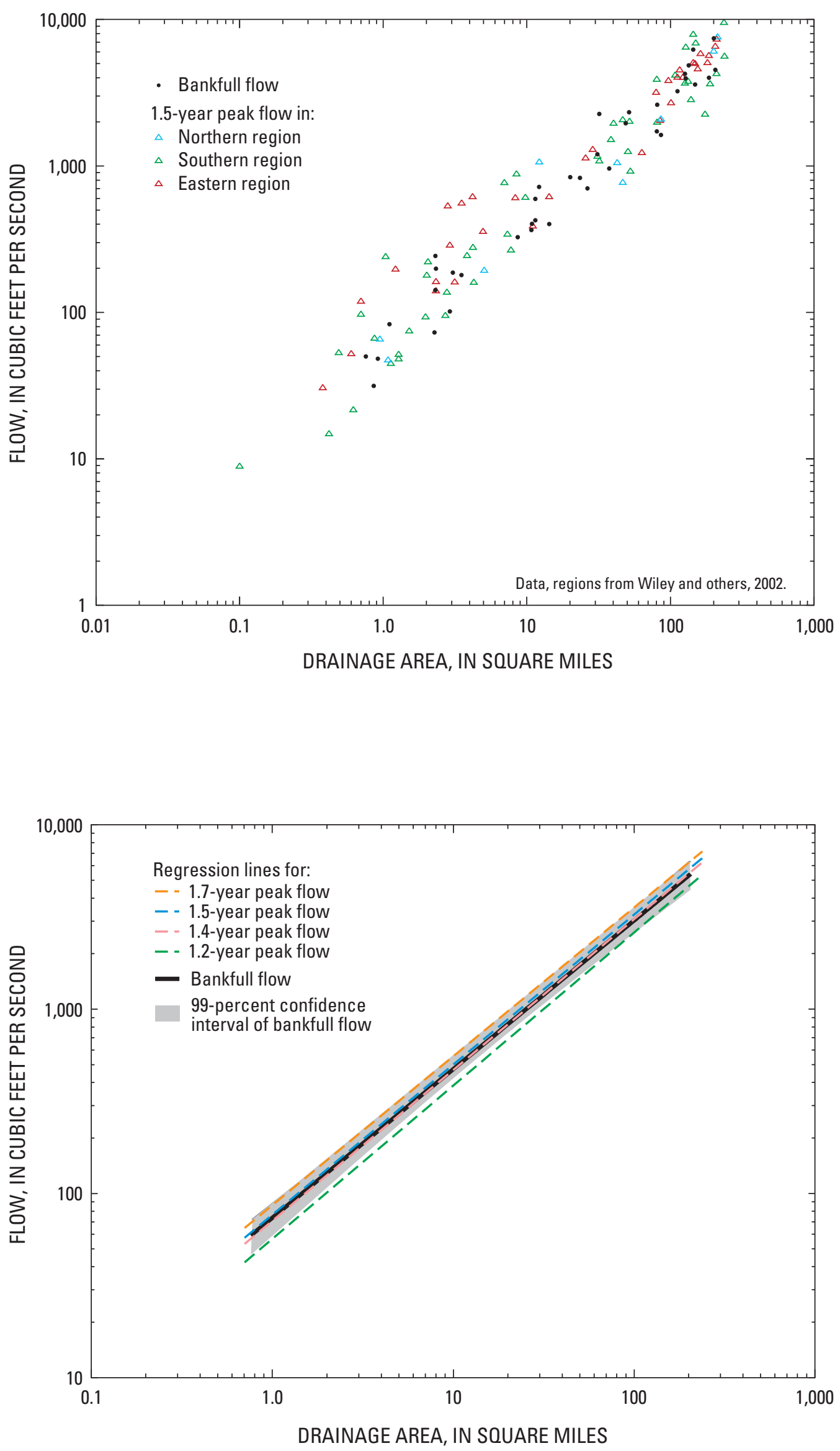

Figure 10. Bankfull flows compared to 1.5-year peak flows measured at streamgages on wadable streams in the Appalachian Plateaus Physiographic Province in West Virginia.

Figure 11. Bankfull flows compared to regression lines for 1.2-, 1.4-, 1.5-, and 1.7-year peak flows measured at streamgages on wadable streams in the Appalachian Plateaus Physiographic Province in West Virginia. 
Table 5. Average bankfull characteristics of streams in the Appalachian Plateaus Physiographic Province in West Virginia.

[ft, feet; $\mathrm{ft}^{2}$, square feet; $\mathrm{ft}^{3} / \mathrm{s}$, cubic feet per second; SF, State Forest; SP, State Park; WMA, Wildlife Management Area]

\begin{tabular}{|c|c|c|c|c|c|}
\hline Site & $\begin{array}{c}\text { Area } \\
\left(\mathrm{ft}^{2}\right)\end{array}$ & $\begin{array}{c}\text { Width } \\
\text { (ft) }\end{array}$ & $\begin{array}{c}\text { Wetted } \\
\text { perimeter } \\
\text { (ft) }\end{array}$ & $\begin{array}{c}\text { Depth } \\
\text { (ft) }\end{array}$ & $\begin{array}{c}\text { Bankfull flow } \\
\left(\mathrm{ft}^{3} / \mathrm{s}\right)\end{array}$ \\
\hline Anglins Creek near Nallen & 267 & 58.7 & 62.5 & 4.54 & 831 \\
\hline Anthony Creek near Anthony & 610 & 136 & 139 & 4.50 & 6,220 \\
\hline Barrenshe Run near Woodbine & 50.3 & 30.8 & 34.5 & 1.63 & 180 \\
\hline Big Draft near Anthony & 43.7 & 34.1 & 37.5 & 1.28 & 187 \\
\hline Big Sandy Creek near Rockville & 871 & 164 & 174 & 5.30 & 7,430 \\
\hline Blackwater River at Davis & 612 & 109 & 114 & 5.61 & 1,630 \\
\hline Buck Run at Leopold & 46.8 & 35.8 & 37.8 & 1.31 & 101 \\
\hline Camp Creek near Camp Creek & 233 & 90.9 & 96.0 & 2.56 & 2,260 \\
\hline Clear Fork at Clear Fork & 582 & 110 & 113 & 5.28 & 4,250 \\
\hline Cranberry River near Richwood & 390 & 108 & 115 & 3.60 & 1,720 \\
\hline East Fork Twelvepole Creek near Dunlow & 238 & 68.0 & 71.3 & 3.50 & 962 \\
\hline Goose Creek near Petroleum & 404 & 78.3 & 83.1 & 5.17 & 2,330 \\
\hline Hurricane Branch at Panther SF & 34.7 & 32.3 & 35.2 & 1.08 & 244 \\
\hline Kings Creek at Weirton & 326 & 94.5 & 98.6 & 3.45 & 1,960 \\
\hline Knob Creek near Wade & 120 & 48.6 & 50.7 & 2.47 & 402 \\
\hline Laurel Fork near Hacker Valley & 103 & 51.4 & 55.4 & 2.00 & 595 \\
\hline Left Fork Clover Run near St. George & 203 & 62.6 & 69.7 & 3.23 & 837 \\
\hline Little Kanawha River near Wildcat & 681 & 160 & 162 & 4.27 & 3,240 \\
\hline Manilla Creek at Amherst-Plymouth WMA & 121 & 46.7 & 48.9 & 2.60 & 365 \\
\hline Marsh Fork of Mash Fork at Camp Creek SF & 40.6 & 29.2 & 33.9 & 1.39 & 142 \\
\hline Middle Fork at Audra & 644 & 147 & 161 & 4.37 & 3,600 \\
\hline Morgan Run near Cheat Lake & 36.3 & 24.0 & 26.4 & 1.51 & 199 \\
\hline North Fork Cherry River near Richwood & 140 & 57.2 & 61.6 & 2.44 & 426 \\
\hline Panther Creek near Panther & 173 & 56.3 & 61.2 & 3.07 & 1,200 \\
\hline Payne Branch near Oakvale & 62.3 & 38.3 & 42.1 & 1.63 & 326 \\
\hline Piney Creek near McCreery & 557 & 131 & 142 & 4.26 & 4,850 \\
\hline Polly Hollow at Kanawha SF & 13.6 & 12.4 & 13.7 & 1.10 & 31.6 \\
\hline Rock Creek near Danville & 162 & 41.4 & 43.7 & 3.91 & 718 \\
\hline Sand Run near Buckhannon & 92.3 & 51.3 & 54.4 & 1.80 & 400 \\
\hline Second Creek near Second Creek & 337 & 114 & 117 & 2.94 & 2,620 \\
\hline Spruce Fork at Cabwaylingo SF & 25.9 & 19.7 & 22.2 & 1.31 & 83 \\
\hline Unnamed Tributary to Hughes River at North Bend SP & 20.5 & 23.5 & 24.5 & 0.87 & 50.0 \\
\hline Upper Nineteenmile Creek at Chief Cornstalk WMA & 24.1 & 19.8 & 20.6 & 1.22 & 48.4 \\
\hline West Fork Greenbrier River above Durbin & 208 & 74.9 & 78.2 & 2.78 & 703 \\
\hline West Fork Little Kanawha River near Rocksdale & 1410 & 154 & 160 & 9.16 & 4,520 \\
\hline Williams River at Dyer & 743 & 148 & 153 & 5.02 & 3,960 \\
\hline Yellow Creek near Davis & 33.5 & 22.2 & 25.0 & 1.51 & 73.1 \\
\hline
\end{tabular}


planning region fit the regression equation well, West Fork Little Kanawha River near Rocksdale was considered more likely to be an outlier or an artifact than to be representative of another region. Payne Branch near Oakvale, the site with the greatest negative residual value, is near the boundary of the Appalachian Plateaus and Valley and Ridge Physiographic Provinces and is in the rain shadow; it plots closer to the regional curve for the Valley and Ridge than it does to the regional curve for the Appalachian Plateaus.

The relation between bankfull width and drainage area varied more than the relation between bankfull flow and drainage area $\left(\mathrm{R}^{2}=0.9492 ; \mathrm{SE}=7.1\right.$ percent; fig. 13). The relation between bankfull depth and drainage area varied the most of the bankfull dimensions $\left(\mathrm{R}^{2}=0.8783 ; \mathrm{SE}=8.9\right.$ percent; fig. 14).

\section{Pattern and Profile}

Near-bankfull high-water-surface slopes ranged from $0.0004 \mathrm{ft} / \mathrm{ft}$ (West Fork Little Kanawha River near Rocksdale) to $0.0544 \mathrm{ft} / \mathrm{ft}$ (Barrenshe Run near Woodbine) (table 6). Generally, mountain streams are steeper than lowland streams, and headwater streams are steeper than higher-order streams. Among the streams that were surveyed, smaller streams were generally steeper than larger streams. This rule had exceptions, such as Piney Creek near McCreery, which is among both the largest and steepest reaches in the study. Some of the flattest reaches in the study (Blackwater River at Davis, Anglins Creek near Nallen, and Williams River at Dyer) are in the most mountainous parts of the study region, and one of the steepest reaches in the study (Polly Hollow at Kanawha State Forest) is at a relatively low elevation.

Sinuosity, the percentage of the reach as either pool or riffle, and near-bankfull high-water-surface slope, at most, weakly correlated between each other. $\mathrm{R}^{2}$ values ranged from 0.02 for the relation between sinuosity and percentage of the reach as riffle to 0.25 for the relation between slope and percentage of reach as riffle.

High-water-mark profiles greatly clarified identification of bankfull features in the field. Because the flagged marks were associated with either a known flow and frequency, or an estimated flow and frequency based on data from nearby streamgages, they provided a second elevation with a known flow, along with the low-water surface, to compare to plausible bankfull characteristics. Although differences in elevation between a feature and the low-water surface can be measured quickly during a survey, the elevation difference alone fails to take into account changes in the other geometric and hydraulic characteristics of the channel, such as width and slope.

Requiring high-water-mark profiles before surveying a site also greatly increased logistic complexity in the study. All sites were visited at least two times. Because peak flows at many sites were uncorrelated with peak flows at gaged index sites, many of the sites were visited three or four times before a near-bankfull peak could be flagged.

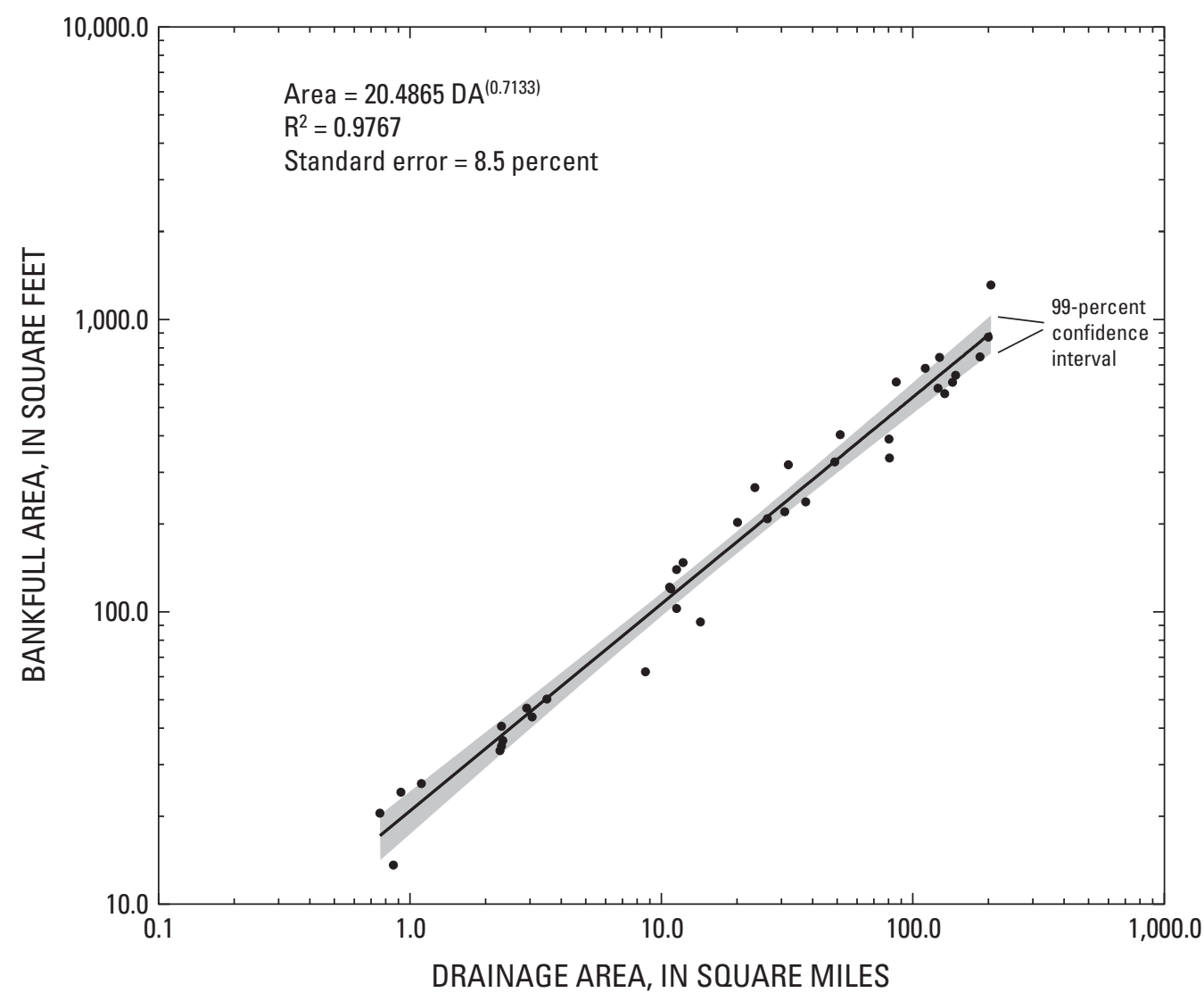

Figure 12. Relation between bankfull area and drainage area for wadable streams in the Appalachian Plateaus Physiographic Province in West Virginia. 

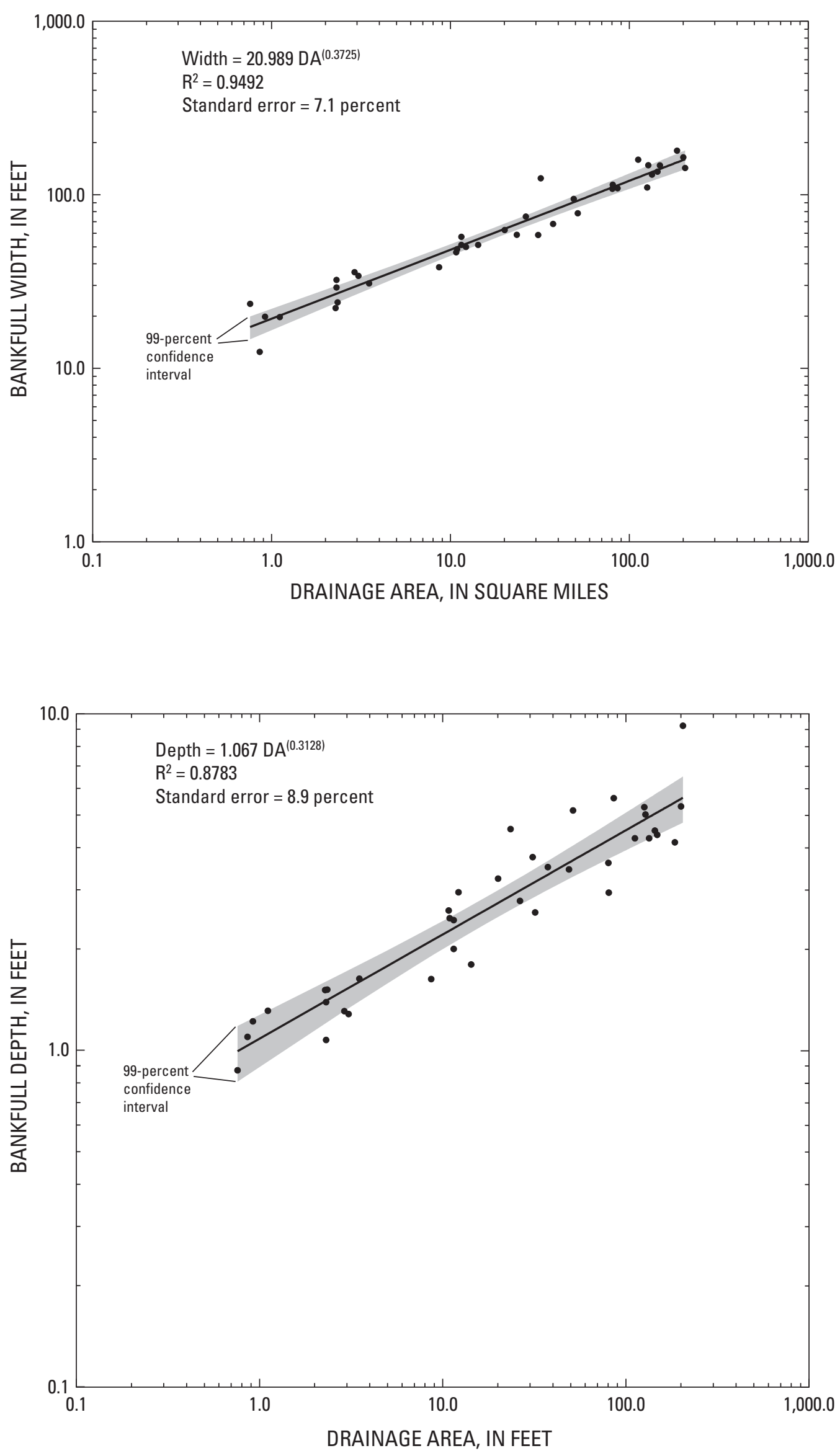

Figure 13. Relation between bankfull width and drainage area for wadable streams in the Appalachian Plateaus Physiographic Province in West Virginia.
Figure 14. Relation between bankfull depth and drainage area for wadable streams in the Appalachian Plateaus Physiographic Province in West Virginia. 
竞

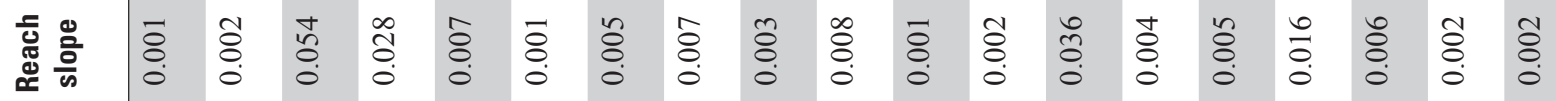

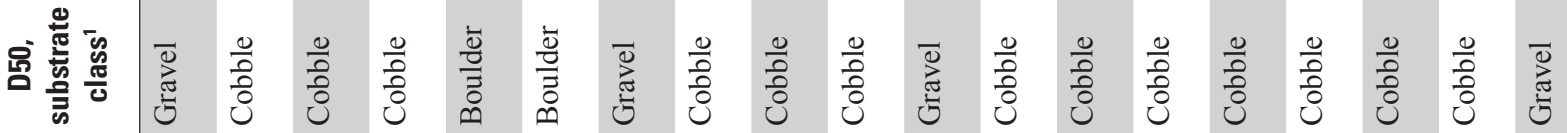
离离

尝

要

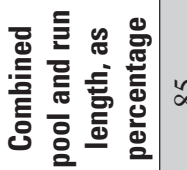

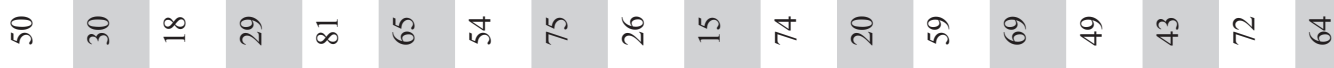

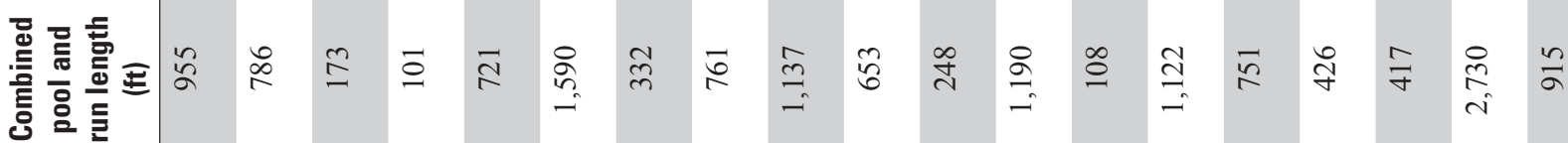

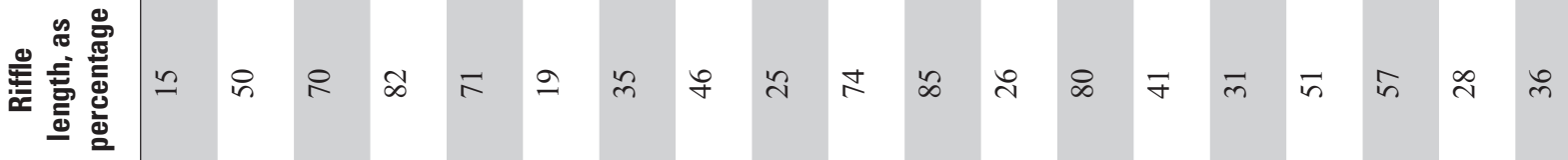
㲤吉玉

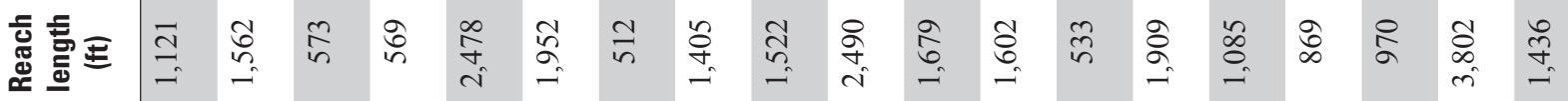

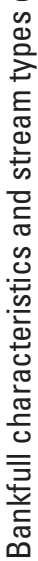
i.
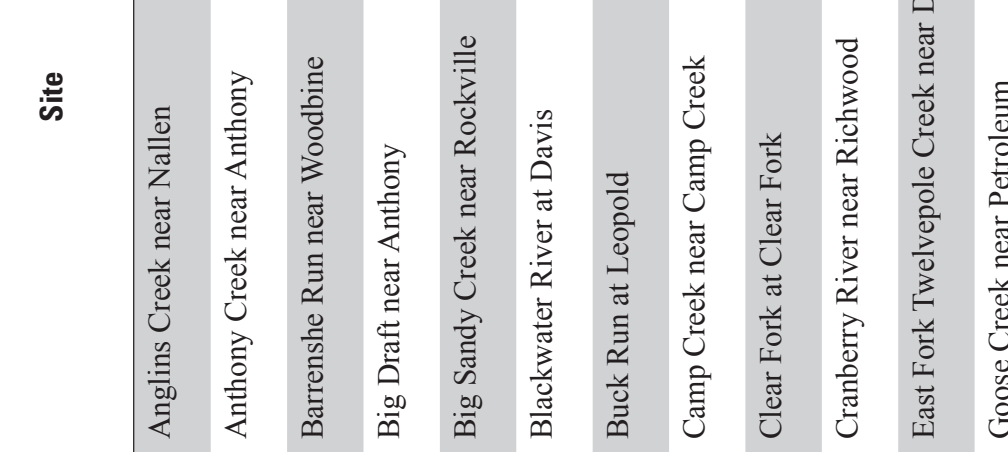

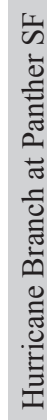

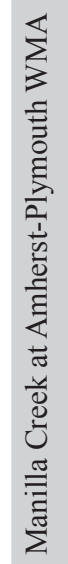




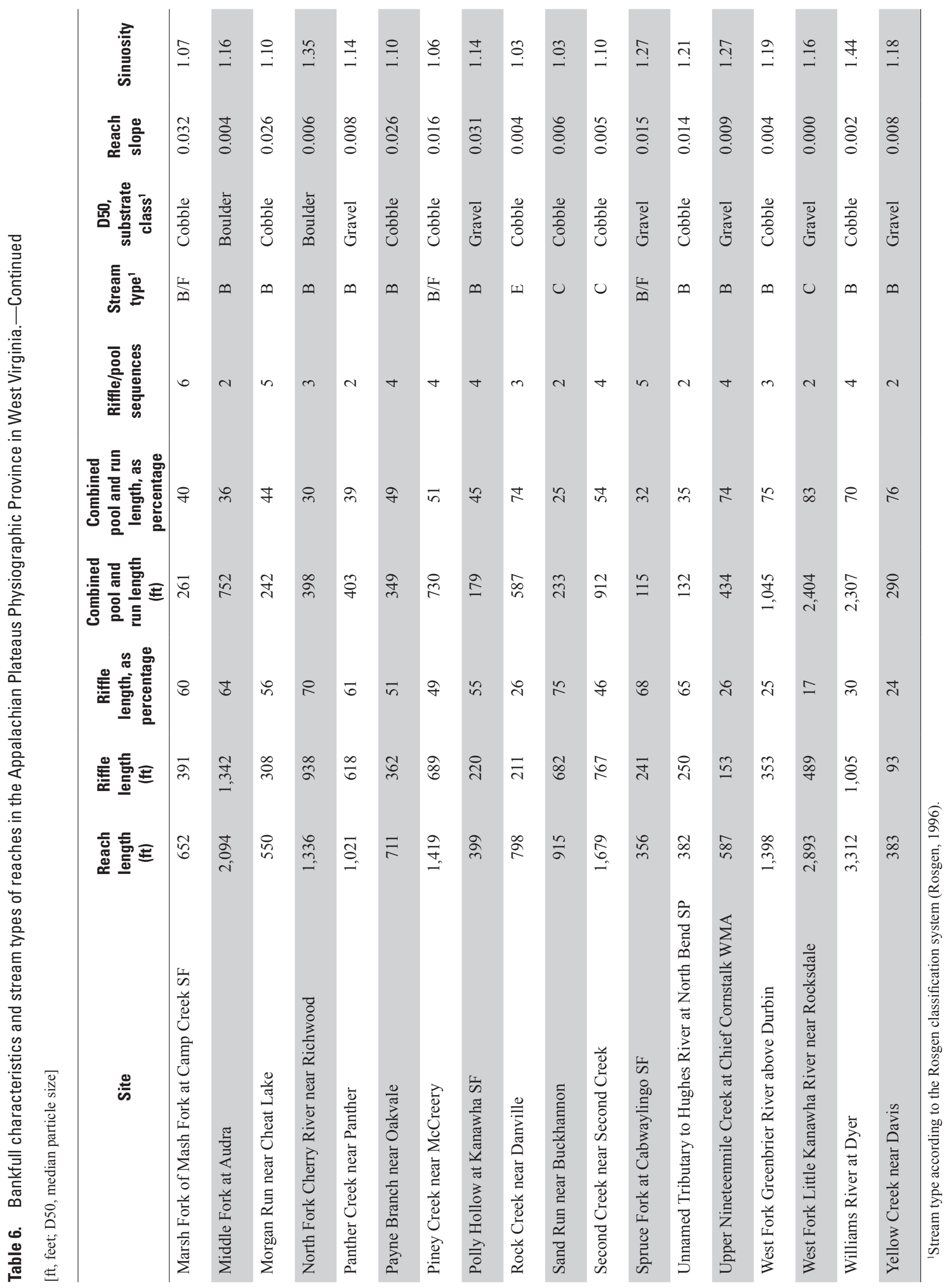




\section{Stream Types}

Rosgen $(1985,1996)$ has published a set of criteria for classifying streams into types, on the basis of, in order of priority: (1) the entrenchment ratio, or the ratio of the floodprone area to bankfull width; (2) the ratio of bankfull width to bankfull mean depth; (3) sinuosity, or the ratio of stream length to valley distance; (4) slope; and (5) channel material. Of the stream reaches surveyed in this study, 27 met criteria of type B, 5 of type C, and 1 of type $\mathrm{E}$ (table 6 ). Three reaches had characteristics that met some criteria for type B and some of type $\mathrm{F}$, and one met some criteria of type $\mathrm{C}$ and of type $\mathrm{E}$.

\section{West Virginia Regional Curves Compared to Regional Curves from Surrounding Areas}

Comparisons with regional curves from previous studies and surrounding areas showed general consistency. Bankfull channel characteristics from West Virginia were intermediate between those from Ohio and Virginia.

Differences in results from among a group of studies are likely to reflect real differences among the study areas when methods and implementation are identical. However, identification of bankfull characteristics is somewhat subjective, and differences have been documented among observers (Roper and others, 2008). Leopold (1994) considered bankfull width to be the most conservative bankfull characteristic, in the sense that when bankfull features are misidentified, the incorrect bankfull width is still likely to be close to the correct value in most streams. Therefore, as the characteristic that is least prone to observer bias, bankfull width is probably the most robust indicator of differences among study areas assessed by different investigators.

\section{Channel Dimensions from Flow Measurements at Streamgages in West Virginia}

Channel dimensions for the 1.5-year flow were determined from current-meter flow measurements made at streamgages in West Virginia to provide an estimate of bankfull dimensions (Messinger and Wiley, 2004). Bankfull flow was not determined in this study. Dimensions were determined for the cross section at each streamgage where high flows were measured, and regional regression equations were developed for the relation between channel dimensions and drainage area. The regression line for the relations between crosssectional area at the 1.5-year flow and drainage area for the Appalachian Plateaus Physiographic Province are within the 99-percent confidence interval of the regional curve for bankfull area for drainage areas less than about $10 \mathrm{mi}^{2}$ (figs.15-17). The areas for the 1.5-year flow were smaller than bankfull areas for the smallest drainage areas considered, but larger for the larger drainage areas, with the greatest difference at the largest drainage areas. Many, if not most, of the cross sections used to develop the estimated areas were in pools, which generally are greater in area than adjacent riffle cross sections. Regional curves were developed from measurements made at riffle cross sections.

Width for the 1.5-year flow at streamgages is slightly less than bankfull width, but the regression line for the width at the 1.5-year flow is within the 99-percent confidence interval for the regional curve for bankfull width (fig. 16). Depth for the 1.5-year flow at streamgages was greater than bankfull depth, and the regression line for depth at the 1.5-year flow was outside the 99-percent confidence interval for the regional curve for bankfull depth in the Appalachian Plateaus (fig.17). Both these relations would be expected when comparing data exclusively from riffles to data predominantly from pools in the same streams.

\section{Valley and Ridge}

Bankfull flow, area, and depth were greater in the Appalachian Plateaus Physiographic Province in West Virginia than in the Valley and Ridge Physiographic Province in Maryland, Virginia, and West Virginia (figs. 15-18; Keaton and others, 2005). The Valley and Ridge receives less mean annual precipitation than does the Appalachian Plateaus in West Virginia, although storm intensity in the Valley and Ridge is greater, as measured by, for example, the 2-year 1-hour maximum precipitation (Hydrometeorological Design Studies Center, 2006a, 2006b).

The Valley and Ridge Physiographic Province in Maryland, Virginia, and West Virginia was to have been studied simultaneously with the Appalachian Plateaus Province in those three states. As a principal study goal, regions were to be determined empirically, based on analysis of bankfull channel characteristics. However, while ongoing, the study was reduced in scope to only the Valley and Ridge Physiographic Province, effectively but arbitrarily setting the boundary between bankfull-channel regions at the boundary between physiographic provinces (Keaton and others, 2005). The present study was undertaken to fill the gap in spatial coverage of bankfull-channel characteristics and, while it concentrated on characterizing the area that had not been studied, offered the opportunity to revisit the previous study's goal of determining regional boundaries. Comparison of bankfull channel characteristics determined in the Valley and Ridge study to those from the present study shows no compelling reason to redraw the existing arbitrary bankfull-channel regional boundary.

Evidence had already been available to suggest that the arbitrary boundary was reasonable; channel dimensions determined for the 1.5-year flow at streamgages in West Virginia were different in the Valley and Ridge and Appalachian Plateaus (Messinger and Wiley, 2004). Bankfull channel characteristics determined in the present study compared to those from the Valley and Ridge regional curve study (Keaton and others, 2005) are clearly different, considering the two areas broadly, but appear to show a transition area between them. Two streams in the Greenbrier or Bluestone River Basins at 


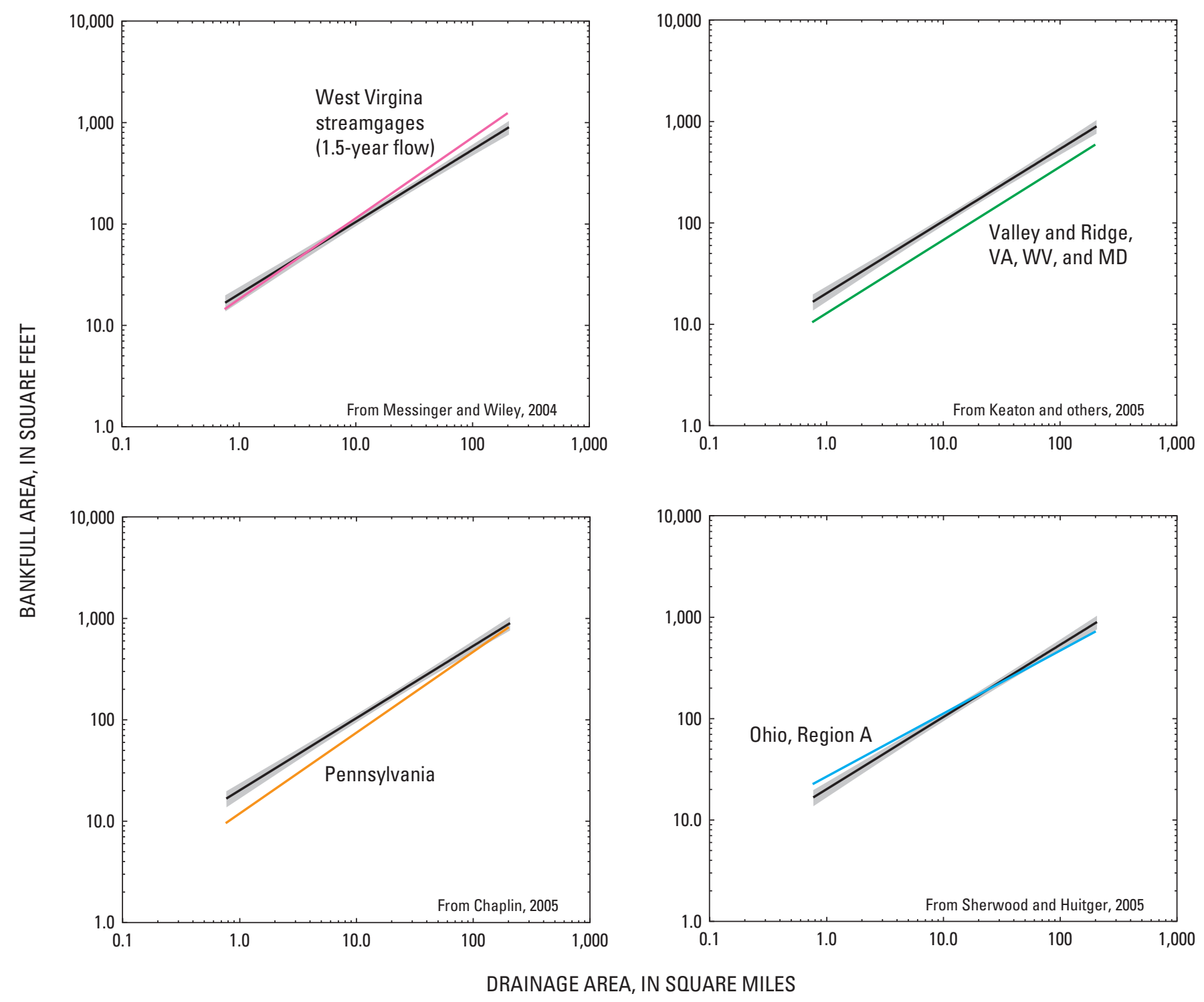

Figure 15. Regional curve (shown in black) and 99-percent confidence interval (shown as gray fill) for bankfull area of wadable streams in the Appalachian Plateaus Province in West Virginia, compared to curves developed for adjacent areas.

the southeastern edge of the study area-Second Creek near Second Creek and Payne Branch near Oakvale — are within the Appalachian Plateaus Province but have bankfull flow, area, width, and depth similar to streams in the Valley and Ridge. However, Anthony Creek near Anthony, which drains parts of both the Appalachian Plateaus and Valley and Ridge, plots at the edge of the main body of values for the Appalachian Plateaus. In contrast, the West Fork of the Greenbrier River above Durbin and Big Draft near Anthony, both in the Greenbrier River Basin, and Marsh Fork at Camp Creek State Forest and Camp Creek near Camp Creek, both in the Bluestone River Basin, all plot well within the main body of bankfull area and depth values for the Appalachian Plateaus. This is not particularly strong support for redrawing the boundary between bankfull channel regions. Parts of the Greenbrier River Basin and the eastern part of the Bluestone River Basin appear to be a transition zone between the two provinces and bankfullchannel regions, where average bankfull channel characteristics are intermediate between the larger regions. This region was identified by Fenneman (1938) as being atypical, in that the boundary between the Valley and Ridge and Appalachian Plateaus Provinces was indistinct here, unlike most of the rest of the boundary from New York to Alabama.

\section{Pennsylvania}

Within Pennsylvania, bankfull channel characteristics of the Appalachian Plateaus were not significantly different from those of other regions that had previously been studied 

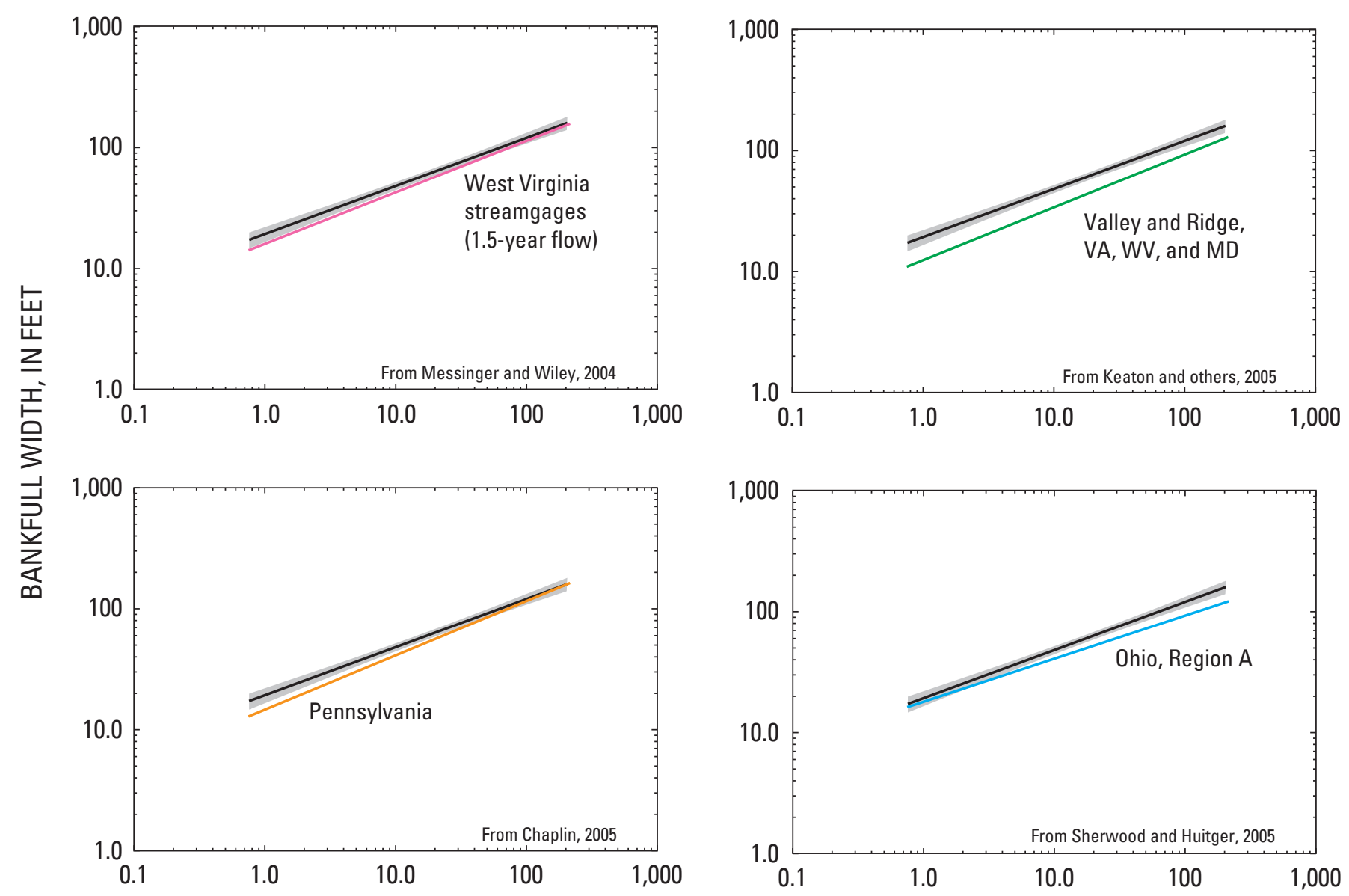

DRAINAGE AREA, IN SQUARE MILES

Figure 16. Regional curve (shown in black) and 99-percent confidence interval (shown as gray fill) for bankfull width of wadable streams in the Appalachian Plateaus Province in West Virginia, compared to curves developed for adjacent areas.

(Chaplin, 2005). Separate regional curves had previously been published for rural parts of the Piedmont and the Valley and Ridge in and near Pennsylvania. After field surveys for rural parts of the Appalachian Plateaus were complete, comparisons were made for bankfull flow and area, and drainage area, among the Piedmont, Valley and Ridge, and Appalachian Plateaus. Differences were not significant, and a single set of regional curves was published for these regions as a unit.

The regression line for bankfull flow in Pennsylvania fell below the lower limit of the 99-percent confidence interval for that in the Appalachian Plateaus of West Virginia (fig. 18). The regression lines for both bankfull area and width in Pennsylvania fall below the 99-percent confidence interval of the comparable regressions for West Virginia in streams draining relatively smaller areas (greater than $20 \mathrm{mi}^{2}$ for width, and greater than $50 \mathrm{mi}^{2}$ for area; figs. 15, 16). The regression line for bankfull depth in Pennsylvania was less than that for West Virginia but mostly fell within the 99-percent confidence interval (fig. 17).

Precipitation is not homogeneous in either West Virginia or Pennsylvania, both of which are mountainous states where the terrain complicates movement of storm fronts and timing and intensity of precipitation. However, most of West Virginia is subject to more intense precipitation than is most of Pennsylvania (Hydrometeorological Design Studies Center, 2006b). Although other differences between the two study areas are abundant and other factors undoubtedly are at play, differences in precipitation intensity and resulting differences in peak flow seem among the most likely factors to cause the differences in bankfull characteristics. 

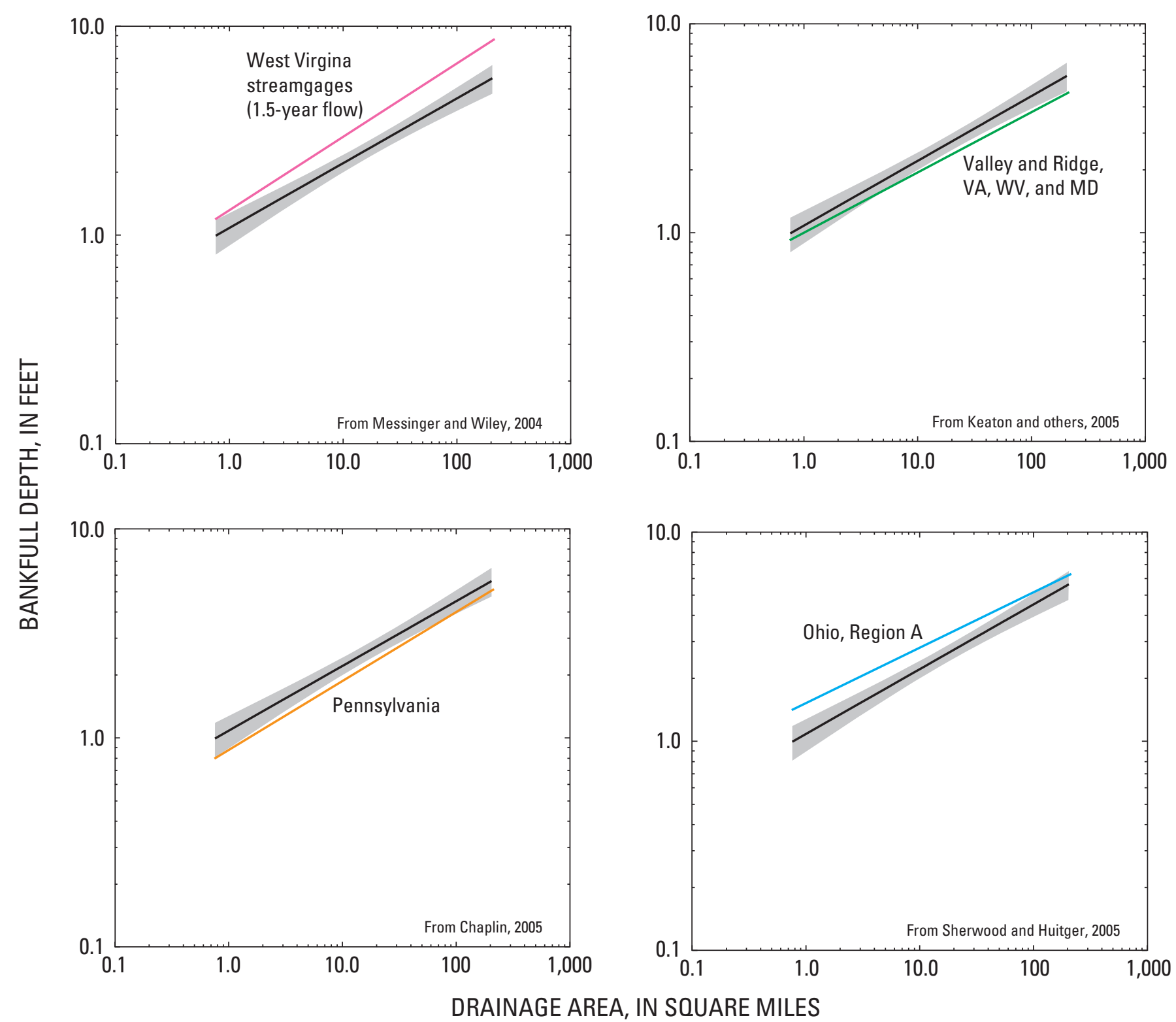

Figure 17. Regional curve (shown in black) and 99-percent confidence interval (shown as gray fill) for bankfull depth of wadable streams in the Appalachian Plateaus Province in West Virginia, compared to curves developed for adjacent areas.

Regional curves for bankfull flow, area, width, and depth for Pennsylvania (Chaplin, 2005) are all intermediate between those for the Appalachian Plateaus in West Virginia and the Valley and Ridge for Maryland, Virginia, and West Virginia (Keaton and others, 2005; figs. 15-18). The Pennsylvania regional curves represent large sections of the Appalachian Plateaus and Valley and Ridge, in addition to the Piedmont. Some of the differences in basin characteristics between the Valley and Ridge and Appalachian Plateaus may be less pronounced in Pennsylvania than farther south. Geology and topography are similar for West Virginia and unglaciated parts of Pennsylvania, but there are differences in climatic factors between the two study areas that determine the frequency and magnitude of bankfull flows. Pennsylvania has a generally colder climate than West Virginia and Virginia and receives relatively more snow and less rain in the winter. Parts of Pennsylvania receive major lake-effect snow storms that can cause snow-melt floods which are uncommon in West Virginia and Virginia.

\section{Ohio}

Regional curves for Ohio were developed following statewide data collection; two regions were delineated using analysis of bankfull characteristics (Sherwood and Huitger, 2005). Sets of equations were published for two regions in 

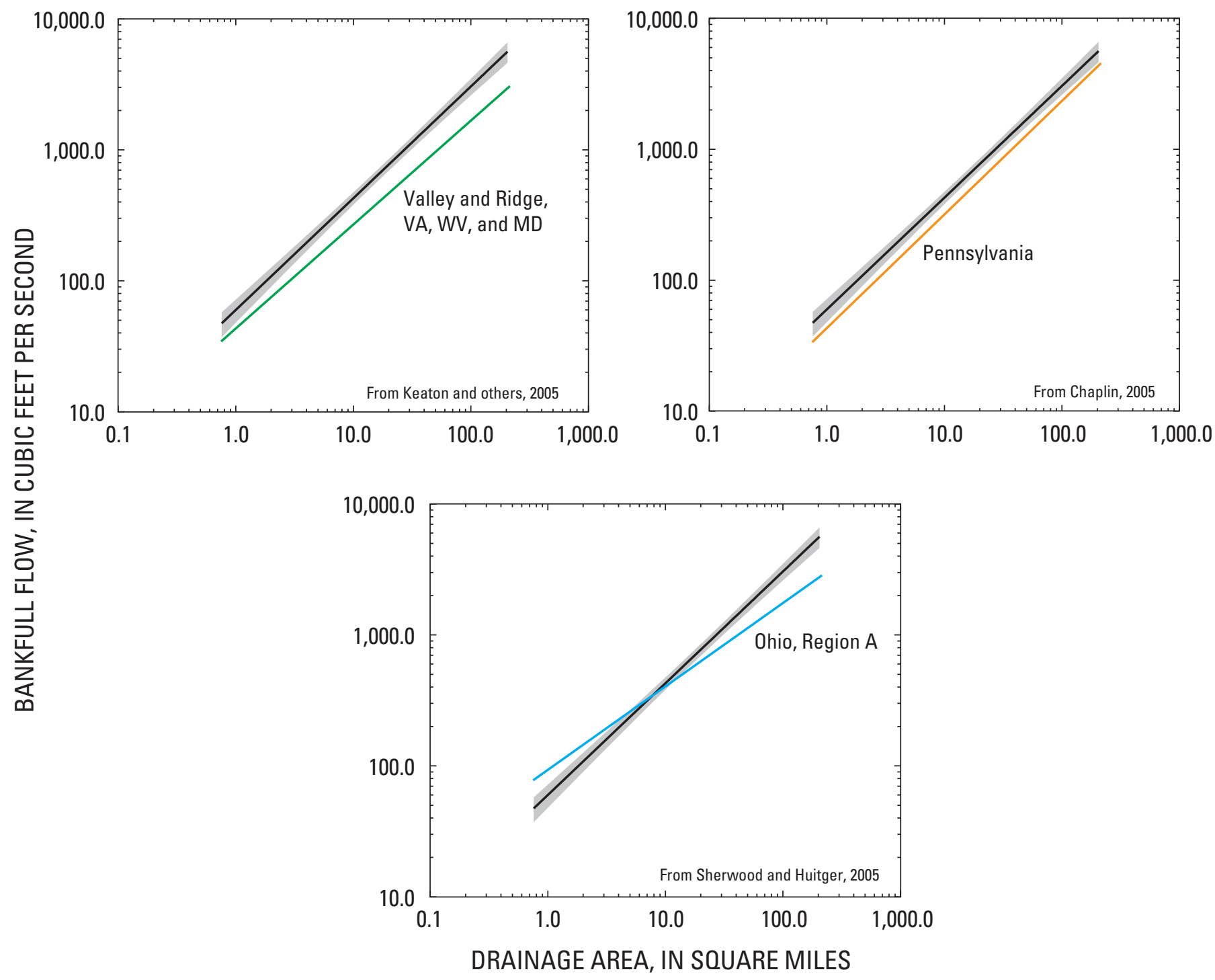

Figure 18. Regional curve and 99-percent confidence interval for bankfull flow of wadable streams in the Appalachian Plateaus Province in West Virginia, compared to curves developed for adjacent areas.

Ohio. For both regions, simple regressions were published for bankfull characteristics in relation to drainage area, and multiple regressions were published for relations between bankfull characteristics, drainage area, and other basin characteristics. The following comparison is drawn with the simple regression equations developed for Ohio Region $\mathrm{A}$, which is composed of the parts of the state within the Appalachian Plateaus and Central Lowlands Physiographic Provinces (Sherwood and Huitger, 2005).

Bankfull area of wadable streams is about the same in West Virginia and Ohio; the Ohio Region A regression line is within the 99-percent confidence interval for the West Virginia equation between about 3 and $200 \mathrm{mi}^{2}$, although the slopes of the two lines diverge with greater drainage areas (fig. 15). Streams in Ohio are deeper and narrower; the Ohio regression line for depth plots above the 99-percent confidence interval for the West Virginia equation at drainage areas less than about $100 \mathrm{mi}^{2}$, but the Ohio regression for width plots below the 99-percent confidence interval for the West Virginia equation for drainage areas greater than about $5 \mathrm{mi}^{2}$ (figs. 16, 17).

The relation between the regression lines for bankfull flow (fig. 18) in Ohio and West Virginia is generally similar to those for bankfull area (fig. 15), although the difference in the slope of the lines is somewhat more pronounced. The bankfull flow equation was developed for a different group of stations than were the equations for the other bankfull characteristics; 
bankfull area, width, and depth were determined for a group of 10 ungaged stations on small streams in Ohio where bankfull flow was not determined. Because of this, bankfull dimensions were not related to flow at the ungaged stations, and the equation for bankfull flow was developed from a group of stations that excluded the small streams.

Part of the difference among regional curves developed in West Virginia and the surrounding states arises from the piecemeal nature of the development of the curves. The curves were developed on a region-by-region basis, and the boundaries of regions were either assumed during study design or delineated within states. The benefit of this approach is that sufficient data were collected to describe conditions in each of the states, and the data were analyzed by individuals familiar with hydrologic and geomorphic conditions within their own state and thus well-positioned to emphasize local concerns. The weaknesses are that (1) questions concerning the most appropriate boundaries between different regions remain unanswered and (2) insufficient evidence may be available to determine whether outliers at the edge of a smaller study area, such as West Fork Little Kanawha River near Rocksdale in this study, are representative of a different region. If sites that should be included in other regions are inappropriately classified, regional curves will be skewed. Investigators and NCD practitioners working in transition areas, regions underrepresented within states, or in some cases even near state lines are left in ambiguous situations as to the most appropriate set of regional curves to use. Examining the results of all available regional curves in transition areas to see if they provide compatible results for a particular drainage area would be a prudent step in a channel-restoration project.

\section{Summary and Conclusions}

Regional curves for bankfull channel characteristics were developed for the part of West Virginia within the Appalachian Plateaus Physiographic Province. Regional curves are regression equations that quantify relations within a region between bankfull channel characteristics and drainage area, and in some cases, other basin characteristics. Natural channel design practitioners use regional curves to design channels or to verify identification of bankfull features in reference reaches. The USGS developed these regional curves in cooperation with the Division of Highways of the West Virginia Department of Transportation and the West Virginia Conservation Agency.

The study area was defined as the part of West Virginia within the Appalachian Plateaus Physiographic Province. Regional-curve planning regions were developed using elevation and mean annual precipitation, the basin characteristics that explained the most variation in a previous study that estimated bankfull channel characteristics by analyzing flow measurements at streamgages. Sites were selected at wadable streams in each of the planning regions across a gradient of drainage areas; a competing goal was for all sites to have stable banks and readily identifiable bankfull features. Because not enough gaged sites were available to meet study goals in size, location, and stability, ungaged sites were added and a slope-area measurement was made of a bankfull or near-bankfull peak. High-water-mark profiles were surveyed at all sites. At ungaged sites, they were used in the slope-area measurement; at gaged sites, they were used to calculate roughness, which in turn was used with the measured slope to determine bankfull flow.

Longitudinal profiles were surveyed through a streamreach length of at least 20 bankfull widths and were composed of two or more riffle-pool sequences. All profiles included thalwegs, water surface, plausible bankfull features, and highwater marks. All cross sections were surveyed in riffles. At least two cross sections were surveyed at gaged sites. These cross sections were extended to an elevation of twice the maximum depth relative to the highest plausible bankfull feature. At ungaged sites, additional cross sections were surveyed at all substantial changes in the slope of the high-water profile.

The high-water-mark profiles were used to supplement or, at most sites, replace the use of channel characteristics estimated from flow measurements at streamgages as a means of choosing among plausible bankfull features at the same station. The frequency of peak flow at ungaged sites was initially estimated by comparison to flow at index streamgages, taking into account local differences in precipitation. The elevation of the high-water mark was then compared to the elevation of the presumptive bankfull feature. All bankfull features surveyed in this study were described and sketched in field notes.

At gaged sites, bankfull flows ranged from less than the 1.1-year peak flow to greater than the 2.0-year peak flow. Regression lines developed for peak flows of wadable (less than $240 \mathrm{mi}^{2}$ ) streams at frequencies ranging from 1.2 to 1.7 years were all within the 99-percent confidence interval of the regression line for bankfull flow. The closest match to the regression equation for bankfull flows was the equation for the 1.4-year peak flow. Drainage area explained slightly more of the variation for bankfull flows $\left(\mathrm{R}^{2}=0.9592\right)$ than it did for 1.5 -year flows measured at streamgages on wadable streams (less than $240 \mathrm{mi}^{2} ; \mathrm{R}^{2}=0.9326$ ).

An $\mathrm{R}^{2}$ value of 0.9768 for bankfull area and of 0.9592 for bankfull flow indicates that little additional variation can be explained by subdividing the study area by region, stream type, geology, or other characteristics. As is typical, the relation between bankfull width and drainage area varied slightly more than those between drainage area and bankfull flow and drainage area and bankfull area. The relation between depth and drainage area varied more than the other bankfull characteristics determined in this study.

Reach slopes ranged from $0.0004 \mathrm{ft} / \mathrm{ft}$ (West Fork Little Kanawha River near Rocksdale) to $0.0544 \mathrm{ft} / \mathrm{ft}$ (Barrenshe Run near Woodbine). Generally, mountain streams are expected to be steeper than lowland streams, and headwater streams are expected to be steeper than higher-order streams, although in this study, both of these generalizations had exceptions. 
Comparisons with regional curves developed in this study with those from previous studies and surrounding areas showed general consistency. Channel dimensions for the 1.5-year flow were determined from current-meter flow measurements made at streamgages in the Appalachian Plateaus of West Virginia, to provide an estimate of bankfull dimensions. The regression line from these estimates for bankfull area fell within the 99-percent confidence interval of the regional curve for bankfull area for drainage areas less than about $10 \mathrm{mi}^{2}$. Cross-sectional area for the 1.5-year flow at streamgages was smaller than bankfull area for the smallest drainage areas considered, but larger for the larger drainage areas, with the greatest difference at the largest drainage areas. Width at the 1.5 -year flow at streamgages was slightly less than bankfull width, but the regression line for the estimate fell within the 99-percent confidence interval for the regression line for bankfull width. Depth at the 1.5-year flow at streamgages was significantly greater than bankfull depth, likely because, at most sites, high-flow current-meter measurements are made in pools.

The regression lines for bankfull flow, area, and depth from the Valley and Ridge in Maryland, Virginia, and West Virginia fell outside the 99-percent confidence interval of regression lines for the Appalachian Plateaus in West Virginia. Channel dimensions at the 1.5-year flow at streamgages in West Virginia had also been significantly different between the Valley and Ridge and Appalachian Plateaus Provinces. When the Valley and Ridge was originally studied, arbitrary regional boundaries were set at the physiographic province boundaries. Although some ambiguity remains as to the precise location of the regional boundary in the Greenbrier River Basin in West Virginia, the present study did not find compelling evidence to redraw the existing regional boundary.

Streams in the part of Pennsylvania outside the Coastal Plain were generally less wide, less deep, and their bankfull flow and area were somewhat smaller than in the Appalachian Plateaus of West Virginia. The parts of the regression lines for bankfull characteristics representing small streams in Pennsylvania fall below the 99-percent confidence interval of the regression lines for the Appalachian Plateaus in West Virginia. Regional curves for bankfull flow, area, width, and depth for Pennsylvania are all intermediate between those for the Appalachian Plateaus in West Virginia and the Valley and Ridge for Maryland, Virginia, and West Virginia. The Pennsylvania curves represent large sections of the Appalachian Plateaus and Valley and Ridge Physiographic Provinces.

Ohio streams are generally deeper and narrower than streams in the Appalachian Plateaus in West Virginia. Bankfull area of wadable streams is about the same in West Virginia and Ohio; the Ohio Region A regression line is within the 99-percent confidence interval for the West Virginia regression line between about 3 and $200 \mathrm{mi}^{2}$, the lines cross at about $20 \mathrm{mi}^{2}$, and the two lines diverge with greater drainage areas. The divergence of the West Virginia and Ohio regression lines for bankfull flow is greater than for bankfull area.

\section{Acknowledgments}

James D. Scott of the USGS West Virginia Water Science Center was instrumental in completing field work for this study. The study was designed following discussions with Jefferson N. Keaton, then of the USGS Virginia Water Science Center, and after Douglas B. Chambers of the USGS West Virginia Water Science Center helped the author survey a reach in a previous study, shortly after a bankfull peak flow. Edward J. Doheny of the USGS Maryland Water Science Center and Jennifer L. Krstolic of the USGS Virginia Water Science Center reviewed the report and provided helpful comments.

\section{References Cited}

Barnes, H.H., 1967, Roughness characteristics of natural channels: U.S. Geological Survey Water-Supply Paper 1849, $213 \mathrm{p}$.

Bernhardt, E.S., 2006, National river restoration science synthesis (NRRSS) statistics page for all node areas, accessed November 18, 2009, at http://nrrss.nbii.gov/info/statistics. html.

Bernhardt, E. S., Palmer, M. A., Allan, J. D., Alexander, G., Barnas, K., Brooks, S., Carr, J., Clayton, S., Dahm, C., Follstad-Shah, J., Galat, D., Gloss, S., Goodwin, P., Hart, D., Hassett, B., Jenkinson, R., Katz, S., Kondolf, G. M., Lake, P. S., Lave, R., Meyer, J. L., O’Donnell, T. K., Pagano, L., Powell, B., and Sudduth, E., 2005, Synthesizing U.S. river restoration efforts: Science, v. 308. no. 5722 , p. 636-637.

Chaplin, J.J., 2005, Development of regional curves relating bankfull-channel geometry and discharge to drainage area for streams in Pennsylvania and selected areas of Maryland: U.S. Geological Survey Scientific Investigations Report 2005-5147, $34 \mathrm{p}$.

Dalrymple, T., and Benson, M.A., 1967, Measurement of peak discharge by the slope-area method: U.S. Geological Survey Techniques of Water-Resources Investigations, book 3, chapter A2.

Dunne, T., and Leopold, L.B., 1978, Water in environmental planning: New York, W.H. Freeman and Company, 818 p.

Fenneman, N.M., 1938, Physiography of Eastern United States: New York, McGraw-Hill, 714 p.

Fenneman, N.M., and Johnson, D.W., 1946, Physical divisions of the United States: U.S. Geological Survey Physiography Committee Special Map, scale 1:7,000,000.

Fulford, J.M., 1994, User's guide to SAC, a computer program for computing discharge by slope-area method: U.S. Geological Survey Open-File Report 94-360. 
Hydrometeorological Design Studies Center, 2006a, Isopluvials of 60 minute precipitation (inches) with average recurrence interval of 2 years, Delaware, District of Columbia, Maryland, New Jersey, Ohio, Pennsylvania, West Virginia: National Oceanic and Atmospheric Administration Atlas 14, Volume 2, Version 3, Ohio River Basin and Surrounding States, accessed November 18, 2009, at http://hdsc.nws. noaa.gov/hdsc/pfds/pfds_maps.html.

Hydrometeorological Design Studies Center, 2006b, Isopluvials of 60 minute precipitation (inches) with average recurrence interval of 2 years, Illinois, Indiana, Ohio: National Oceanic and Atmospheric Administration Atlas 14, Volume 2, Version 3, Ohio River Basin and Surrounding States, accessed November 18, 2009, at http://hdsc.nws.noaa.gov/ hdsc/pfds/pfds_maps.html.

Jarrett, R.D., 1984, Hydraulics of high-gradient streams: Journal of Hydraulic Engineering, v. 110, no. 11, p. 1519-1539.

Keaton, J.N., Messinger, T., and Doheny, E.J., 2005, Development and analysis of regional curves for streams in the non-urban Valley and Ridge Physiographic Province, Maryland, Virginia, and West Virginia: U.S. Geological Survey Scientific Investigations Report 2005-5076, 116 p.

Leopold, L.B., 1994, A view of the river: Cambridge, MA, Harvard University Press, 298 p.

Leopold, L.B., Wolman, M.G., and Miller, J.P., 1964, Fluvial processes in geomorphology: New York, Dover Publications, $522 \mathrm{p}$.

Limerinos, J.T., 1970, Determination of the Manning coefficient from measured bed roughness in natural channels: U.S. Geological Survey Water-Supply Paper 1898-B, 47 p.

Messinger, Terence, and Hughes, C.A., 2000, Environmental setting and its relations to water quality in the Kanawha River Basin: U.S. Geological Survey Water-Resources Investigations Report 00-4020, 57 p.

Messinger, Terence, and Wiley, J.B., 2004, Regional relations in bankfull channel characteristics at selected stream-gaging stations in West Virginia, 1911-2002 : U.S. Geological Survey Water-Resources Investigations Report 03-4276, 43 p.

Rantz, S.E., and others, 1982, Measurement and computation of streamflow-Volume 1. Measurement of stage and discharge; Volume 2. Computation of discharge: U.S. Geological Survey Water-Supply Paper 2175, 631 p.

Roper, B., Buffington, J.M., Archer, E., Moyer, C., and Ward, M., 2008, The role of observer variation in determining Rosgen stream types in northeastern Oregon mountain streams: Journal of American Water Resources Association, v. 44 , no. 2 , p. 417-427.
Rosgen, D. L., 1985, A stream classification system: Riparian Ecosystems and their Management: Proceedings of the First North American Riparian Conference, April 16-18, Tucson, Arizona, USDA Forest Service General Technical Report No. RM-120, p. 91-95.

Rosgen, D.L., 1996, Applied river morphology: Pagosa Springs, CO, Wildland Hydrology, variously paged.

Sherwood, J.M., and Huitger, C.A., 2005, Bankfull characteristics of Ohio streams and their relation to peak streamflows: U.S. Geological Survey Scientific Investigations Report 2005-5153, 38 p.

U.S. Army Corps of Engineers, 2009, HEC-RAS, accessed November 18, 2009, at http://www.hec.usace.army.mil/ software/hec-ras/.

U.S. Census Bureau, 2009, West Virginia quick facts, accessed November 18, 2009, at http://quickfacts.census.gov/qfd/ states $/ 54000 . h t m l$.

U.S. Census Bureau, 2001, 2000 Incorporated Places/Census Designated Places, accessed November 18, 2009, at http://www.census.gov/geo/www/cob/pl2000.html.

US Department of Commerce, 1960, Climate of the States, West Virginia: Weather Bureau, Climatography of the U.S., no. $60-46,15 \mathrm{p}$.

U.S. Geological Survey, 2006, National Atlas of the United States, State Boundaries of the United States, accessed November 18, 2009, at http://nationalatlas.gov/atlasftp. html.

U.S. Geological Survey, 1999, National Elevation Dataset, accessed November 18, 2009, at http://ned.usgs.gov/.

U.S. Geological Survey, 1991, 1:2,000,000-scale Digital Line Graph files of streams, accessed November 18, 2009, at http://water.usgs.gov/lookup/getspatial?stream.

West Virginia Department of Environmental Protection, 2005, Updated list of waters of special concern being proposed for tier 2.5 anti-degradation protection status, accessed November 18, 2009, at http://www.wvdep.org/dwwm/antideg/ new4web.htm.

Wiley, J.B., Atkins, J.T., and Newell, D.A., 2002, Estimating the magnitude of annual peak discharges with recurrence intervals between 1.1 and 3.0 years for rural, unregulated streams in West Virginia: U.S. Geological Survey WaterResources Investigations Report 02-4164, 73 p.

Wolf, P.R., and Ghilani, C.D., 2002, Elementary surveying - an introduction to geomatics: Upper Saddle River, NJ, Prentice-Hall, 900 p. 


\section{Tables 2 and 4}


Table 2. Description of bankfull features, sediment particle size, and Manning's roughness coefficient for stream cross sections in the Appalachian Plateaus Physiographic Province, West Virginia.

[XS, cross-section number; D84, 84th percentile of particle size; D50, median particle size; n, Manning's coefficient of roughness; ft, feet; s, second; FP, floodplain; LBF, left bankfull; RBF, right bankfull; BR, bedrock; nd, not done]

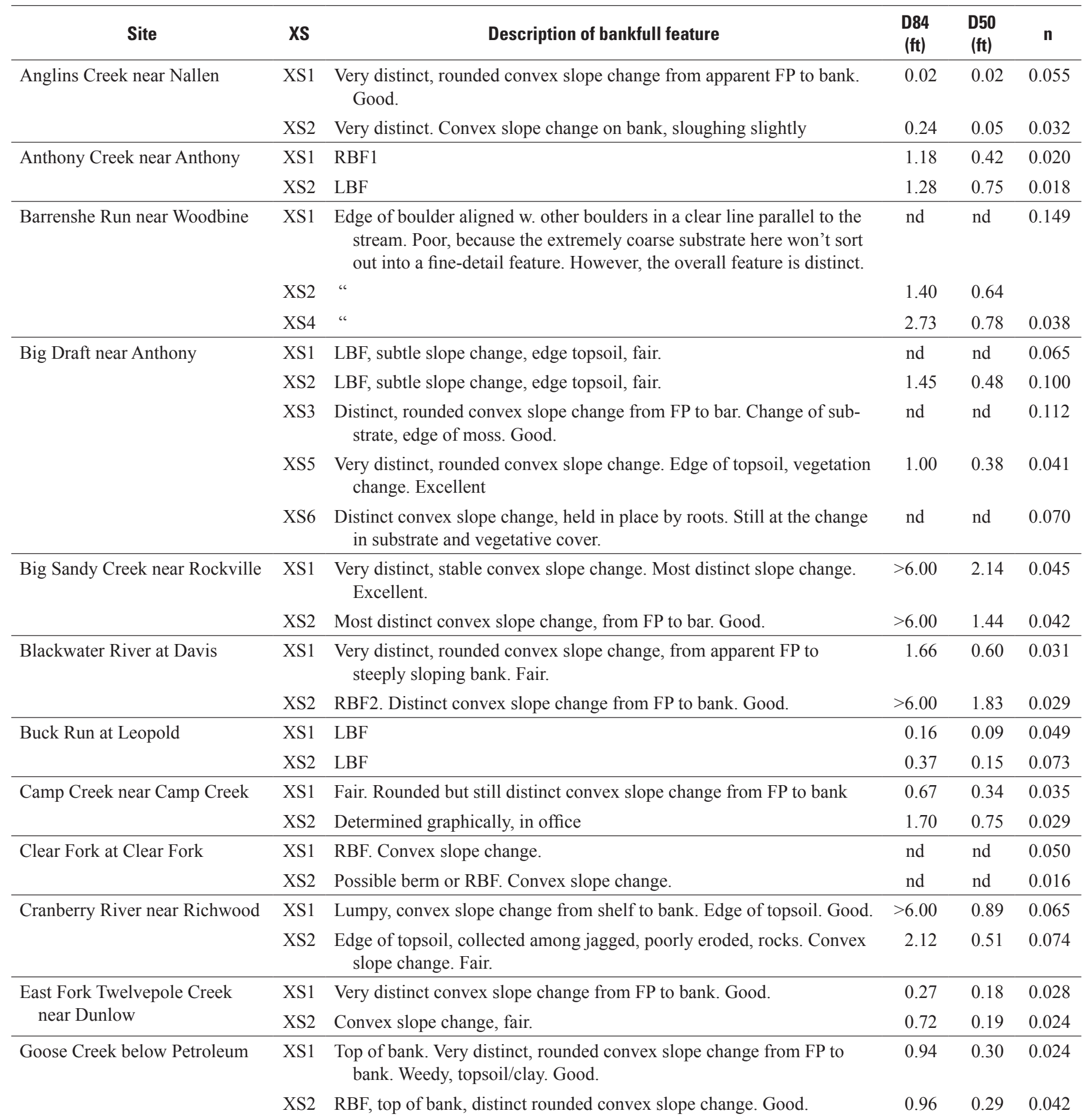


Table 2. Description of bankfull features, sediment particle size, and Manning's roughness coefficient for stream cross sections in the Appalachian Plateaus Physiographic Province, West Virginia.—Continued

[XS, cross-section number; D84, 84th percentile of particle size; D50, median particle size; n, Manning's coefficient of roughness; ft, feet; s, second; FP, floodplain; LBF, left bankfull; RBF, right bankfull; BR, bedrock; nd, not done]

\begin{tabular}{|c|c|c|c|c|c|}
\hline Site & XS & Description of bankfull feature & $\begin{array}{l}\text { D84 } \\
\text { (ft) }\end{array}$ & $\begin{array}{l}\text { D50 } \\
\text { (ft) }\end{array}$ & $\mathbf{n}$ \\
\hline \multirow[t]{5}{*}{ Hurricane Branch at Panther SF } & XS1 & Determined graphically, in office & nd & nd & 0.033 \\
\hline & $\mathrm{XS} 2$ & Determined graphically, in office & nd & nd & 0.023 \\
\hline & $\mathrm{XS} 3$ & Determined graphically, in office & nd & nd & 0.037 \\
\hline & XS4 & $\begin{array}{l}\text { Poor. Distinct convex slope change from poorly defined FP to extreme- } \\
\text { ly steep bank, recovering from being undercut. }\end{array}$ & nd & nd & 0.042 \\
\hline & XS6 & LBF & nd & nd & 0.086 \\
\hline \multirow[t]{5}{*}{ Kings Creek at Weirton } & XS1 & $\begin{array}{l}\text { Top of bank. Very distinct, stable, convex slope change. Most distinct } \\
\text { feature. Good }\end{array}$ & 0.86 & 0.43 & 0.023 \\
\hline & XS2 & Top of bank. Most distinct, stable of the features. Good & $\mathrm{BR}$ & $\mathrm{BR}$ & 0.059 \\
\hline & XS3 & Top of bank, only distinct feature. Good & nd & nd & 0.042 \\
\hline & XS4 & Most distinct feature of XS. Good & nd & nd & 0.044 \\
\hline & XS5 & $\begin{array}{l}\text { Distinct but gradual, stable convex slope change from FP to bank. } \\
\text { Good. Most distinct feature. }\end{array}$ & nd & nd & 0.030 \\
\hline \multirow[t]{7}{*}{ Knob Creek near Wade } & XS1 & RBF. Subtle, convex slope change. Near edge of moss. Poor & nd & nd & 0.079 \\
\hline & XS2 & $\begin{array}{l}\text { A break in the bedrock ledge. Edge of very thin topsoil. Extremely } \\
\text { poor. }\end{array}$ & $>6.00$ & 0.36 & 0.067 \\
\hline & $\mathrm{XS} 3$ & Most distinct of several convex slope changes. Edge of grass. Fair. & nd & nd & 0.050 \\
\hline & XS4 & Lumpy; convex slope change in soil. Poor. & nd & nd & 0.042 \\
\hline & XS5 & Rounded, convex slope change. Fair. & 0.87 & 0.30 & \\
\hline & XS7 & Indistinct convex slope change. Poor. & nd & nd & 0.056 \\
\hline & XS8 & Fairly distinct, gradual, convex slope change. Fair. & nd & nd & 0.048 \\
\hline \multirow[t]{5}{*}{ Laurel Fork near Hacker Valley } & XS1 & $\begin{array}{l}\text { Bank top. Abrupt slope change from FP to bank; some slumping. Lower } \\
\text { of the two banks. }\end{array}$ & nd & nd & 0.067 \\
\hline & $\mathrm{XS} 2$ & $\begin{array}{l}\text { Very distinct convex slope change in cobble/boulder bar. Continuous. } \\
\text { Good. }\end{array}$ & nd & nd & 0.049 \\
\hline & XS4 & $\begin{array}{l}\text { Very distinct convex slope change in cobble/boulder bar. Continuous. } \\
\text { Good. }\end{array}$ & 0.84 & 0.45 & 0.058 \\
\hline & XS5 & $\begin{array}{l}\text { RBF. Very distinct, gently rounded convex slope change from FP to } \\
\text { bank. Good. }\end{array}$ & nd & nd & 0.063 \\
\hline & XS6 & Convex slope change. & 0.81 & 0.29 & 0.067 \\
\hline \multirow{5}{*}{$\begin{array}{l}\text { Left Fork Clover Run near St. } \\
\text { George }\end{array}$} & XS1 & Most distinct slope change, from FP to apparent bank. & nd & nd & 0.054 \\
\hline & $\mathrm{XS} 2$ & $\begin{array}{l}\text { Fairly distinct convex slope change; at edge of tree line; part of nice } \\
\text { continuous line clearly visible from across stream. Fair. }\end{array}$ & nd & nd & 0.040 \\
\hline & XS3 & Rounded, mossy. Just above high-water mark. Fair. & 0.58 & 0.28 & 0.048 \\
\hline & XS4 & Top of bank. & nd & nd & 0.048 \\
\hline & XS5 & Top of bank. Most distinct convex slope change. & 0.60 & 0.32 & 0.042 \\
\hline \multirow{2}{*}{$\begin{array}{l}\text { Little Kanawha River near } \\
\text { Wildcat }\end{array}$} & XS1 & RBF. Convex slope change on a complex bank. Fair. & 0.68 & 0.27 & 0.039 \\
\hline & XS2 & LBF. Convex slope change on a complex bank. Fair. & 0.48 & 0.33 & 0.036 \\
\hline
\end{tabular}


Table 2. Description of bankfull features, sediment particle size, and Manning's roughness coefficient for stream cross sections in the Appalachian Plateaus Physiographic Province, West Virginia.-Continued

[XS, cross-section number; D84, 84th percentile of particle size; D50, median particle size; n, Manning's coefficient of roughness; ft, feet; s, second; FP, floodplain; LBF, left bankfull; RBF, right bankfull; BR, bedrock; nd, not done]

\begin{tabular}{|c|c|c|c|c|c|}
\hline Site & XS & Description of bankfull feature & $\begin{array}{c}\text { D84 } \\
\text { (ft) }\end{array}$ & $\begin{array}{l}\text { D50 } \\
\text { (ft) }\end{array}$ & $\mathbf{n}$ \\
\hline \multirow[t]{4}{*}{$\begin{array}{l}\text { Manilla Creek at Amherst- } \\
\text { Plymouth WMA }\end{array}$} & XS1 & $\begin{array}{l}\text { Sketch, field notes show this as berm. Lower of } 2 \text { convex slope } \\
\text { changes. }\end{array}$ & nd & nd & 0.048 \\
\hline & XS2 & $\begin{array}{l}\text { Sketch, field notes show this as berm. Lower of } 2 \text { convex slope } \\
\text { changes. }\end{array}$ & nd & nd & 0.037 \\
\hline & $\mathrm{XS} 3$ & $\begin{array}{l}\text { Sketch, field notes show this as berm. Lower of } 2 \text { convex slope } \\
\text { changes. }\end{array}$ & nd & nd & 0.049 \\
\hline & XS4 & Determined graphically, in office. & nd & nd & 0.051 \\
\hline \multirow{3}{*}{$\begin{array}{l}\text { Marsh Fork of Mash Fork at } \\
\text { Camp Creek SF }\end{array}$} & XS1 & Determined graphically, in office. & 1.35 & 0.35 & 0.077 \\
\hline & $\mathrm{XS} 3$ & Determined graphically, in office. & nd & nd & 0.081 \\
\hline & XS4 & $\begin{array}{l}\text { Good. Convex slope change from FP to bank. Change of substrate, soil } \\
\text { to rock. }\end{array}$ & nd & nd & 0.080 \\
\hline \multirow[t]{2}{*}{ Middle Fork at Audra } & XS1 & $\begin{array}{l}\text { Between HWM3 \& } 4 \text {. Distinct, rounded convex slope change held by } \\
\text { large hemlock root. Fair. }\end{array}$ & 5.08 & 1.92 & 0.042 \\
\hline & XS2 & Edge of boulder. Effective LBF; some boulders to its left & $>6.00$ & 2.65 & 0.047 \\
\hline \multirow[t]{4}{*}{ Morgan Run near Cheat Lake } & XS1 & Distinct, stable-looking convex slope change, anchored by roots. Fair. & $\mathrm{BR}$ & BR & 0.047 \\
\hline & XS2 & $\begin{array}{l}\text { Very distinct, stable-looking convex slope change from gently sloping } \\
\text { to very steep. Rocky bank, with accumulated topsoil. Good. }\end{array}$ & nd & nd & 0.047 \\
\hline & XS3 & Very distinct, stable convex slope change from FP to bank. Excellent. & nd & nd & 0.078 \\
\hline & XS5 & $\begin{array}{l}\text { Mossy topsoil accumulated on huge boulder; convex slope change. } \\
\text { Good. }\end{array}$ & nd & nd & 0.115 \\
\hline \multirow{4}{*}{$\begin{array}{l}\text { North Fork Cherry River near } \\
\text { Richwood }\end{array}$} & XS4 & Distinct, rounded slope change. Mossy soil. Good & nd & nd & 0.072 \\
\hline & XS5 & Distinct, rounded slope change. Mossy soil. Good & nd & nd & 0.070 \\
\hline & XS6 & $\begin{array}{l}\text { Very poor. Convex slope change, thin layer of mossy dirt on a boulder } \\
\text { in outside of bend. }\end{array}$ & nd & nd & 0.074 \\
\hline & XS7 & Rounded, edge of soil. Fair. & nd & nd & 0.128 \\
\hline \multirow[t]{3}{*}{ Panther Creek near Panther } & XS1 & Convex slope change. Poor. Determined from plot. & nd & nd & 0.037 \\
\hline & XS2 & Edge of topsoil. Poor & 2.43 & 0.85 & 0.035 \\
\hline & XS3 & Subtle convex slope change on a gently sloping bank. Fair & 1.54 & 0.55 & 0.043 \\
\hline
\end{tabular}


Table 2. Description of bankfull features, sediment particle size, and Manning's roughness coefficient for stream cross sections in the Appalachian Plateaus Physiographic Province, West Virginia.—Continued

[XS, cross-section number; D84, 84th percentile of particle size; D50, median particle size; n, Manning's coefficient of roughness; ft, feet; s, second; FP, floodplain; LBF, left bankfull; RBF, right bankfull; BR, bedrock; nd, not done]

\begin{tabular}{|c|c|c|c|c|c|}
\hline Site & XS & Description of bankfull feature & $\begin{array}{l}\text { D84 } \\
\text { (ft) }\end{array}$ & $\begin{array}{l}\text { D50 } \\
\text { (ft) }\end{array}$ & n \\
\hline \multirow[t]{6}{*}{ Payne Branch near Oakvale } & XS1 & RBF. Convex slope change, fair & 1.38 & 0.80 & 0.057 \\
\hline & XS2 & RBF. Convex slope change, fair & nd & nd & 0.083 \\
\hline & $\mathrm{XS} 3$ & $\begin{array}{l}\text { Rounded, gradual but distinct convex slope change at top of the bank. } \\
\text { Fair. }\end{array}$ & nd & nd & 0.054 \\
\hline & XS4 & $\begin{array}{l}\text { Rounded, gradual but distinct convex slope change at top of the bank. } \\
\text { Fair. }\end{array}$ & nd & nd & 0.067 \\
\hline & XS5 & $\begin{array}{l}\text { Rounded, gradual but distinct convex slope change at top of the bank. } \\
\text { Fair. }\end{array}$ & nd & nd & 0.064 \\
\hline & XS6 & Convex slope change. Poor. Determined from plot. & 0.98 & 0.47 & 0.044 \\
\hline \multirow[t]{5}{*}{ Piney Creek near McCreery } & XS1 & Change of substrate. Poor. & nd & nd & 0.068 \\
\hline & XS2 & Convex slope change. Poor. Determined from plot. & nd & nd & 0.057 \\
\hline & $\mathrm{XS} 3$ & $\begin{array}{l}\text { Edge of pointy, entrained boulder. Boulder tops form an acceptable line. } \\
\text { Fair. One of the best features in this reach. }\end{array}$ & nd & nd & 0.091 \\
\hline & XS4 & $\begin{array}{l}\text { Edge of apparent terrace. Most distinct of several convex slope } \\
\text { changes. }\end{array}$ & nd & nd & 0.063 \\
\hline & XS5 & $\begin{array}{l}\text { Top of boulder. Part of a line, fairly distinct, along right bank. Boulder } \\
\text { has an exceptionally distinct convex slope change at this point, ap- } \\
\text { pears to be shaped by water. Poor. }\end{array}$ & nd & nd & 0.060 \\
\hline \multirow[t]{7}{*}{ Polly Hollow at Kanawha SF } & $\mathrm{XS1}$ & $\begin{array}{l}\text { Lower of two convex slope changes. LBF? berm? Most distinct feature } \\
\text { on left side. }\end{array}$ & 0.50 & 0.17 & 0.119 \\
\hline & XS2 & RBF. Good. Distinct change in slope at edge of FP & 0.76 & 0.21 & 0.105 \\
\hline & XS3 & LBF, edge of topsoil, convex slope change, fair. & nd & nd & 0.091 \\
\hline & XS4 & LBF, very distinct convex slope change anchored by tree roots. Good. & nd & nd & 0.151 \\
\hline & XS5 & Convex slope change. Poor. Determined from plot. & nd & nd & 0.101 \\
\hline & XS6 & Convex slope change. Poor. Determined from plot. & nd & nd & 0.095 \\
\hline & XS7 & Fair at best-- cobble at edge of gravelly soil. & nd & nd & 0.104 \\
\hline \multirow[t]{2}{*}{ Rock Creek near Danville } & XS1 & Abrupt convex slope change from FP to bank. Poor. & 0.40 & 0.26 & 0.049 \\
\hline & XS2 & Rounded convex slope change from FP to bank. Good. & 0.47 & 0.21 & 0.052 \\
\hline \multirow[t]{2}{*}{ Sand Run near Buckhannon } & XS1 & RBF. One of several convex slope changes, below the top of bank. Fair. & 0.55 & 0.33 & 0.038 \\
\hline & $\mathrm{XS} 2$ & LBF. Convex slope change. Fair. & 0.70 & 0.36 & 0.039 \\
\hline \multirow{2}{*}{$\begin{array}{l}\text { Second Creek near Second } \\
\text { Creek }\end{array}$} & XS1 & Good. Very clear, distinct convex slope change between bank and FP. & 0.65 & 0.35 & 0.027 \\
\hline & $\mathrm{XS} 2$ & Good. Distinct convex slope change from FP to bank. & 0.99 & 0.48 & 0.029 \\
\hline \multirow[t]{6}{*}{ Spruce Fork at Cabwaylingo SF } & XS1 & $\begin{array}{l}\text { RBF. Fair. Very distinct change in slope; edge of soil on a small over- } \\
\text { hanging rock shelf. }\end{array}$ & nd & nd & 0.057 \\
\hline & $\mathrm{XS} 2$ & Distinct convex slope change on bank. Continuous. Good. & nd & nd & 0.052 \\
\hline & XS3 & Convex slope change. Fair. & nd & nd & 0.098 \\
\hline & XS4 & RBF. Convex slope change. Fair. & nd & nd & 0.076 \\
\hline & XS5 & Top of bank. Distinct convex slope change. Good. & nd & nd & 0.084 \\
\hline & XS6 & Top of bank. Distinct convex slope change. Good. & nd & nd & 0.054 \\
\hline
\end{tabular}


Table 2. Description of bankfull features, sediment particle size, and Manning's roughness coefficient for stream cross sections in the Appalachian Plateaus Physiographic Province, West Virginia.-Continued

[XS, cross-section number; D84, 84th percentile of particle size; D50, median particle size; n, Manning's coefficient of roughness; ft, feet; s, second; FP, floodplain; LBF, left bankfull; RBF, right bankfull; BR, bedrock; nd, not done]

\begin{tabular}{|c|c|c|c|c|c|}
\hline Site & XS & Description of bankfull feature & $\begin{array}{l}\text { D84 } \\
\text { (ft) }\end{array}$ & $\begin{array}{l}\text { D50 } \\
\text { (ft) }\end{array}$ & $\mathbf{n}$ \\
\hline \multirow[t]{5}{*}{$\begin{array}{l}\text { Unnamed Tributary to Hughes } \\
\text { River }\end{array}$} & XS1 & $\begin{array}{l}\text { RBF. Very distinct, rounded convex slope change from FP to bank. } \\
\text { Good. }\end{array}$ & nd & nd & 0.067 \\
\hline & XS2 & LBF. Very distinct convex slope change from FP to bar. Good. High? & nd & nd & 0.065 \\
\hline & XS3 & LBF. Very distinct convex slope change from FP to bar. Good. High? & nd & nd & 0.066 \\
\hline & XS4 & LBF. Very distinct convex slope change from FP to bar. Good. High? & 0.27 & 0.14 & 0.129 \\
\hline & XS5 & Distinct, rounded convex slope change at edge of FP. Good. & 0.44 & 0.23 & 0.058 \\
\hline \multirow{6}{*}{$\begin{array}{l}\text { Upper Nineteenmile Creek at } \\
\text { Chief Cornstalk WMA }\end{array}$} & XS1 & Lowest convex slope change. Poor. Determined from plot. & 0.23 & 0.14 & 0.057 \\
\hline & XS2 & Lowest convex slope change. Poor. Determined from plot. & 0.26 & 0.13 & 0.047 \\
\hline & XS3 & LBF or berm. Convex slope change. Lowest distinct feature & nd & nd & 0.085 \\
\hline & XS4 & Lowest convex slope change. Poor. Determined from plot. & nd & nd & 0.100 \\
\hline & XS5 & $\begin{array}{l}\text { Distinct convex slope change. Mossy dirt; obvious fluvial sand below. } \\
\text { Good. }\end{array}$ & nd & nd & 0.123 \\
\hline & XS6 & Lowest convex slope change. Poor. Determined from plot. & nd & nd & 0.066 \\
\hline \multirow[t]{8}{*}{$\begin{array}{l}\text { West Fork Greenbrier River } \\
\text { above Durbin }\end{array}$} & XS1 & $\begin{array}{l}\text { Very distinct, formerly eroded convex slope change from FP to bank. } \\
\text { Very mossy, rounded, anchored by roots. Good. }\end{array}$ & nd & nd & 0.046 \\
\hline & $\mathrm{XS} 2$ & $\begin{array}{l}\text { Lower inflection of a wide, gradual convex slope change from FP to } \\
\text { bank. Good. }\end{array}$ & 0.94 & 0.61 & 0.033 \\
\hline & $\mathrm{XS} 3$ & $\begin{array}{l}\text { Very distinct, rounded, convex slope change from FP to bank, just } \\
\text { above apparent bar. Good. }\end{array}$ & nd & nd & 0.046 \\
\hline & XS4 & $\begin{array}{l}\text { Very distinct, rounded, convex slope change from FP to bank, just } \\
\text { above apparent bar. Good. }\end{array}$ & nd & nd & 0.046 \\
\hline & XS5 & $\begin{array}{l}\text { Bermish, lumpy soil, moss-covered; convex slope change, fairly dis- } \\
\text { tinct. Fair. }\end{array}$ & nd & nd & 0.057 \\
\hline & XS6 & $\begin{array}{l}\text { Rounded, convex slope change from FP to bank. Held by roots, topsoil. } \\
\text { Good. }\end{array}$ & 1.35 & 0.69 & 0.066 \\
\hline & XS7 & $\begin{array}{l}\text { Most distinct, and lower, inflection in a gradual convex slope change. } \\
\text { Fair. }\end{array}$ & nd & nd & 0.044 \\
\hline & XS8 & Convex slope change. Fair. & nd & nd & 0.055 \\
\hline \multirow[t]{2}{*}{$\begin{array}{l}\text { West Fork Little Kanawha River } \\
\text { near Rocksdale }\end{array}$} & XS1 & $\begin{array}{l}\text { Top of bank. Sharp convex slope change from FP to steeply sloping } \\
\text { bank. Old slump that has weeded up and stabilized. Fair }\end{array}$ & 0.35 & 0.16 & 0.039 \\
\hline & XS2 & Top of bank. Very distinct, rounded. Good. & 0.36 & 0.10 & 0.040 \\
\hline \multirow[t]{3}{*}{ Williams River at Dyer } & XS1 & $\begin{array}{l}\text { Rounded convex slope change on lower bank, anchored by roots. Field- } \\
\text { identified as berm. Fair. }\end{array}$ & 6.00 & 2.61 & 0.035 \\
\hline & $\mathrm{XS} 2$ & $\begin{array}{l}\text { Rounded convex slope change on lower bank. Field-identified as berm. } \\
\text { Fair. }\end{array}$ & 1.09 & 0.29 & 0.055 \\
\hline & XS3 & Edge of FP; level for long way. Inside of bend. & nd & nd & 0.039 \\
\hline \multirow[t]{5}{*}{ Yellow Creek near Davis } & XS1 & Convex slope change at edge of FP. Some sloughing. Poor. & 1.27 & 0.27 & 0.081 \\
\hline & $\mathrm{XS} 2$ & LBF, Lower of two convex slope changes. Fair. & nd & nd & 0.080 \\
\hline & XS3 & RBF. Convex slope change. Fair. & 0.95 & 0.12 & 0.113 \\
\hline & XS4 & Convex slope change at edge of FP. Good. & nd & nd & 0.047 \\
\hline & XS5 & LBF. Distinct convex slope change. Good. & nd & nd & 0.048 \\
\hline
\end{tabular}




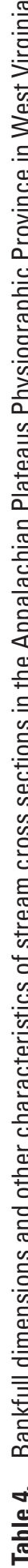

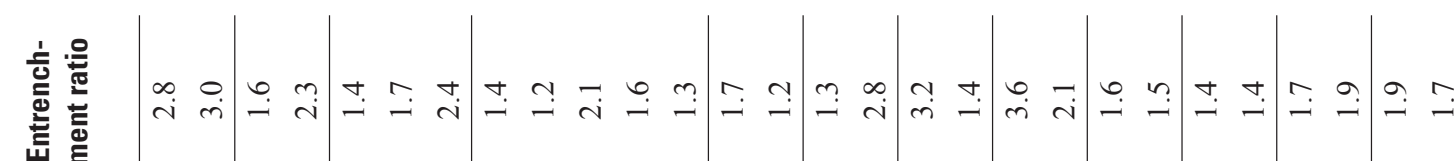

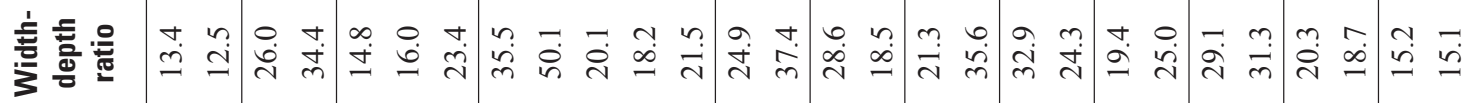

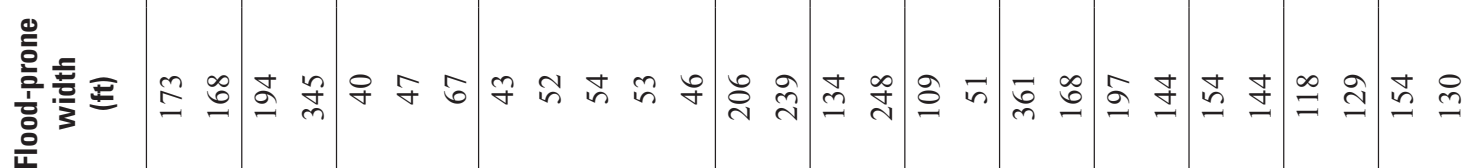

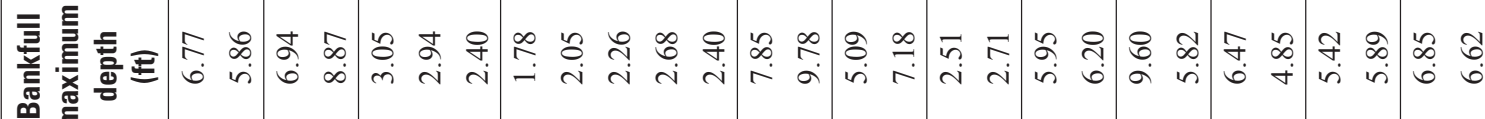

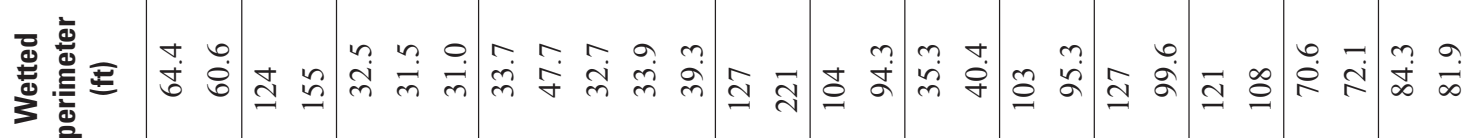

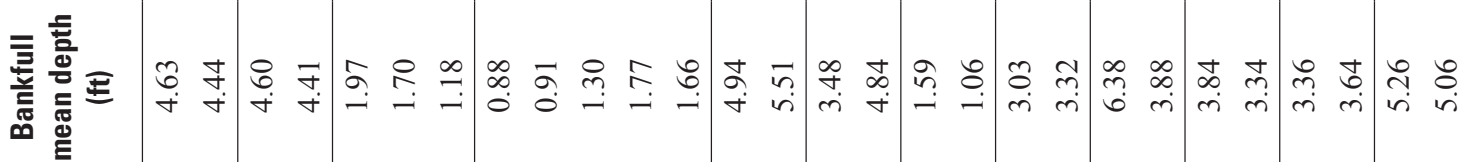

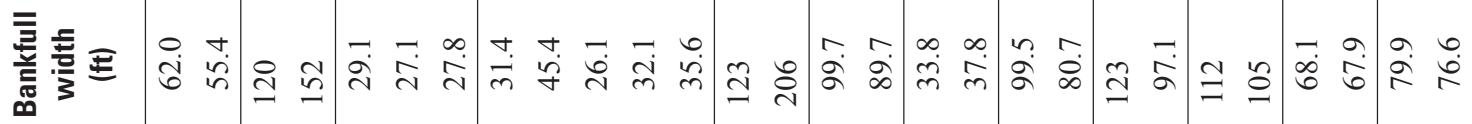

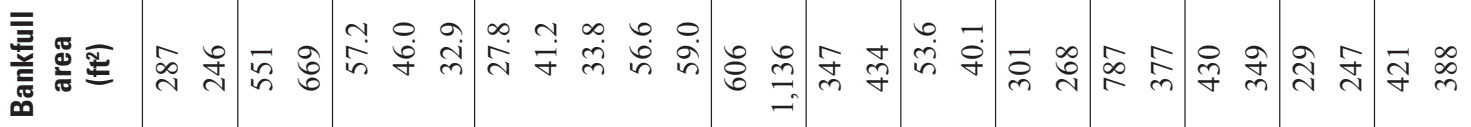

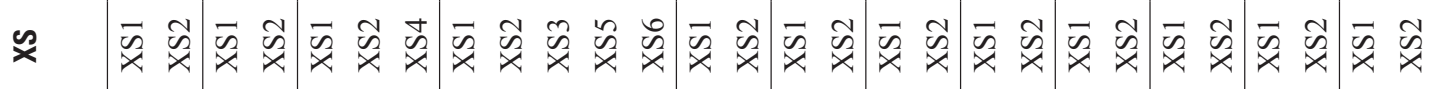




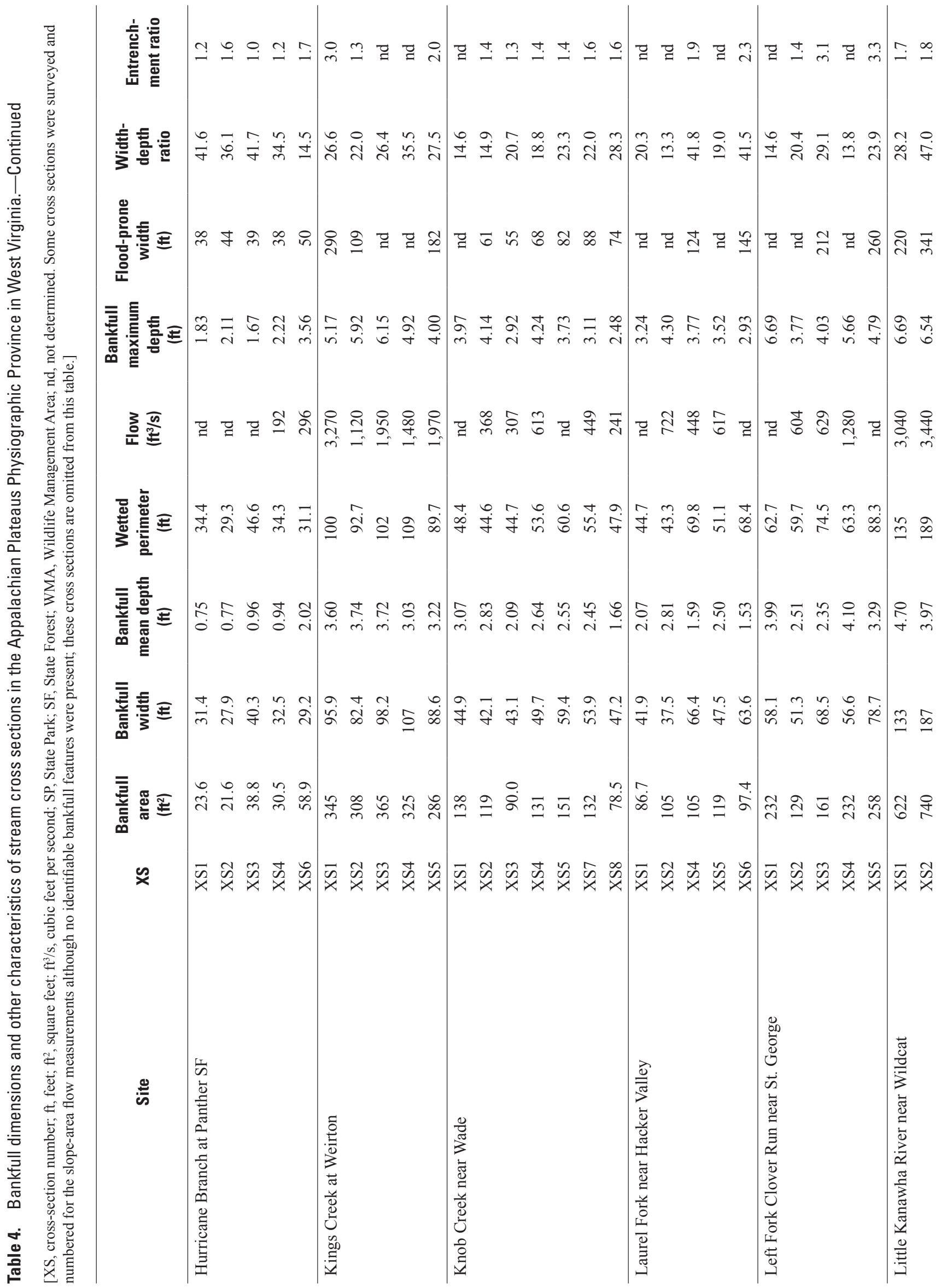



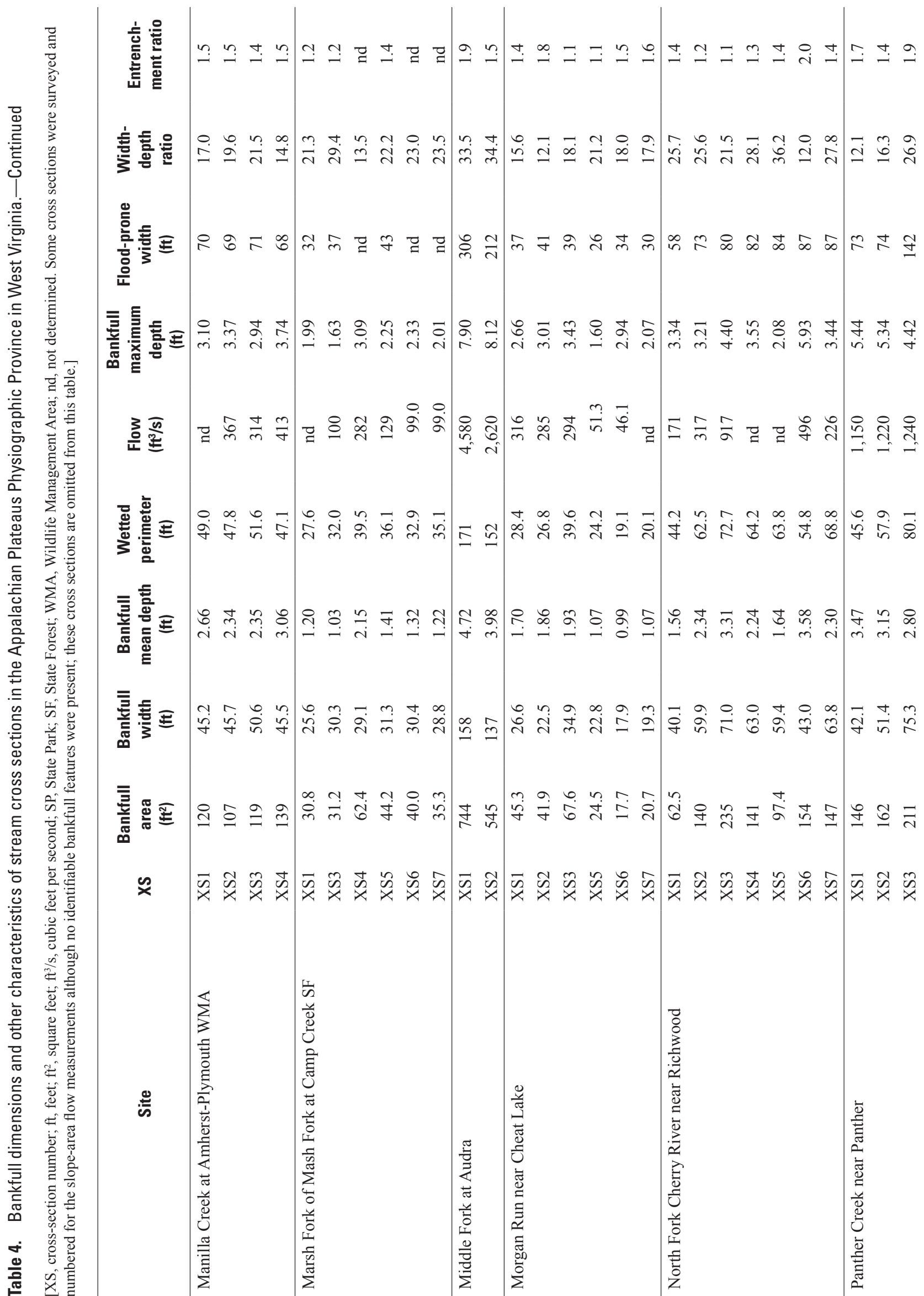

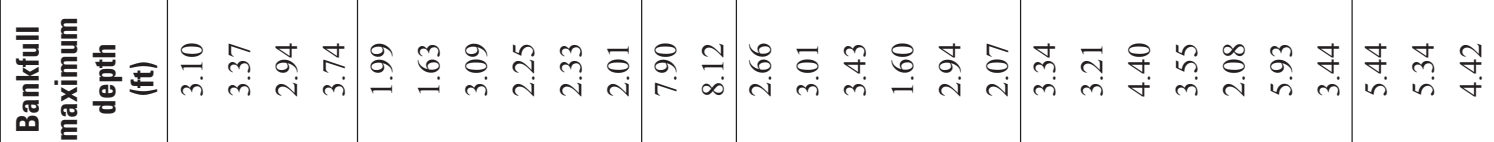

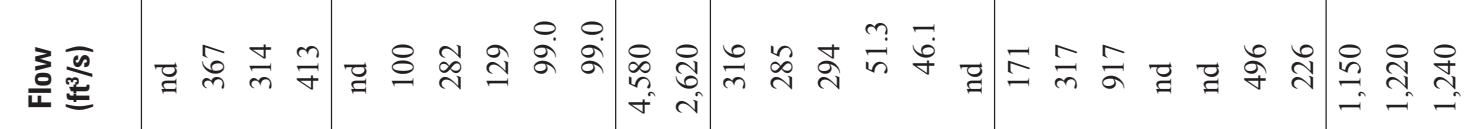

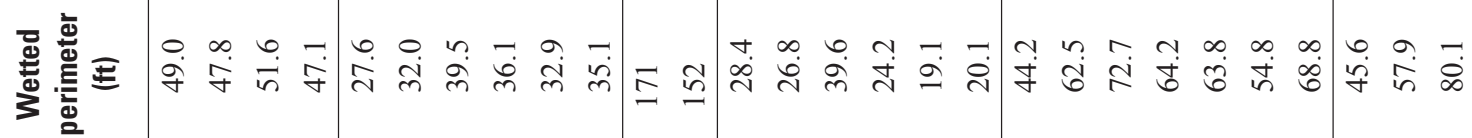

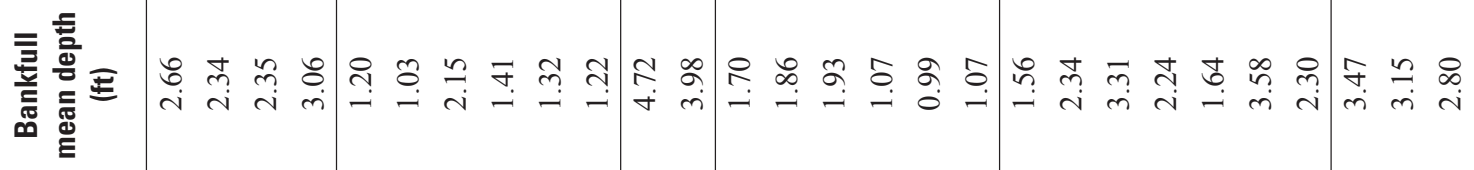

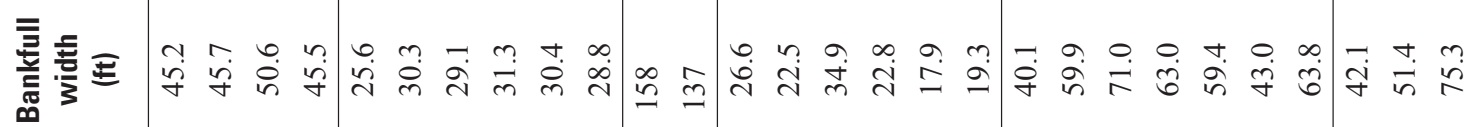

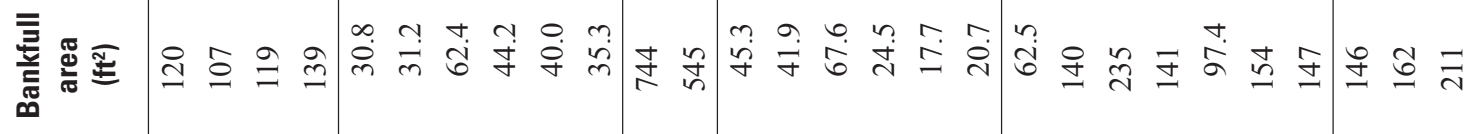

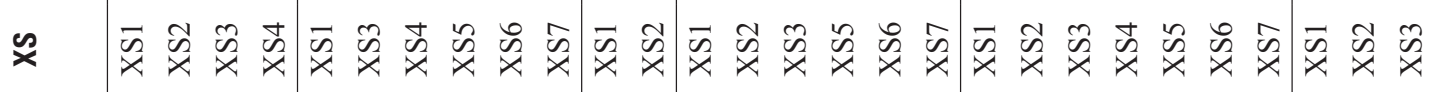




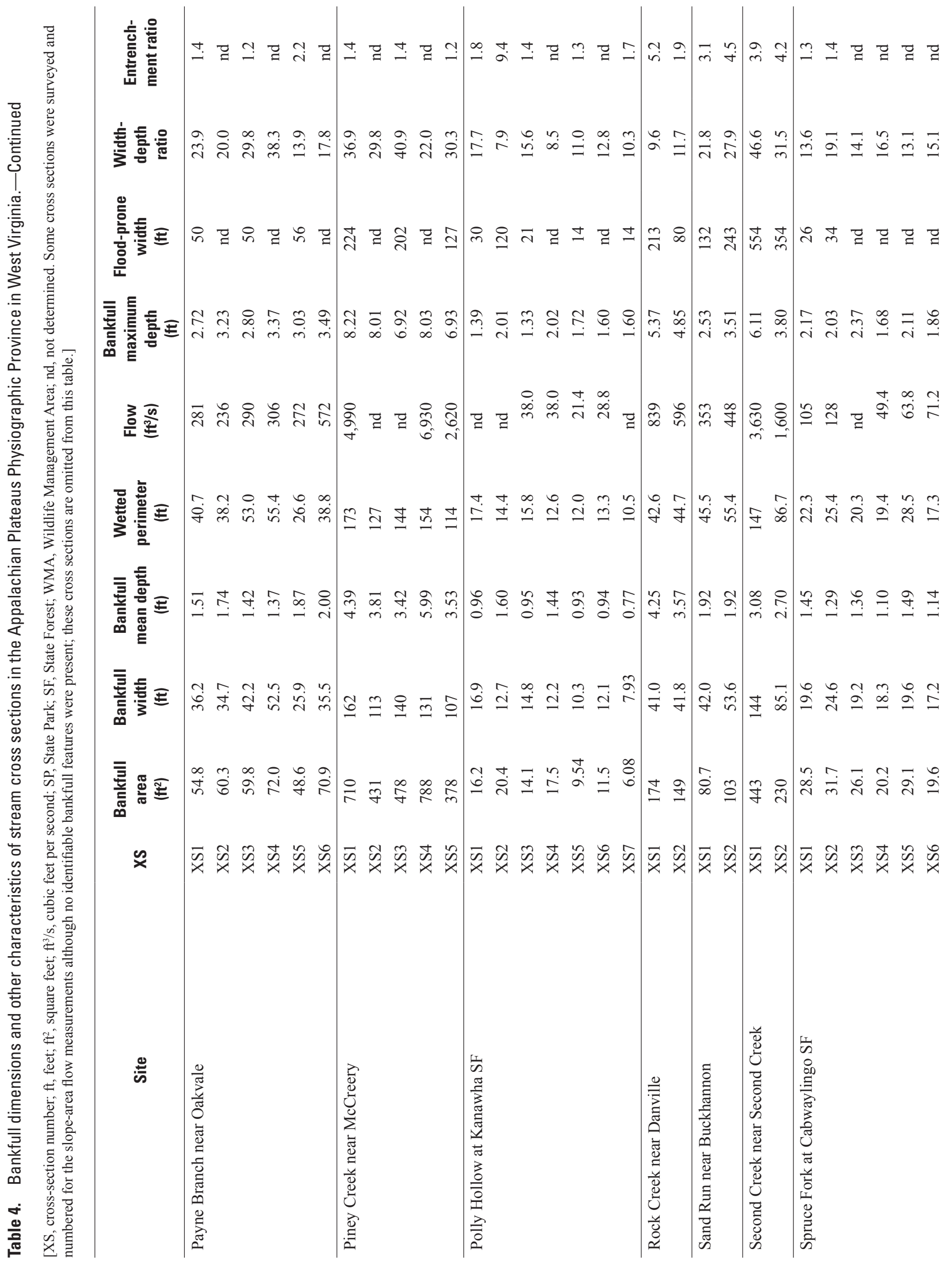


Table 4

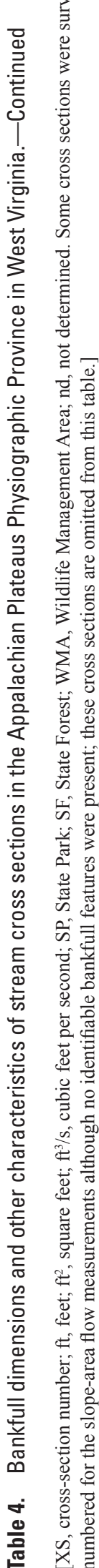

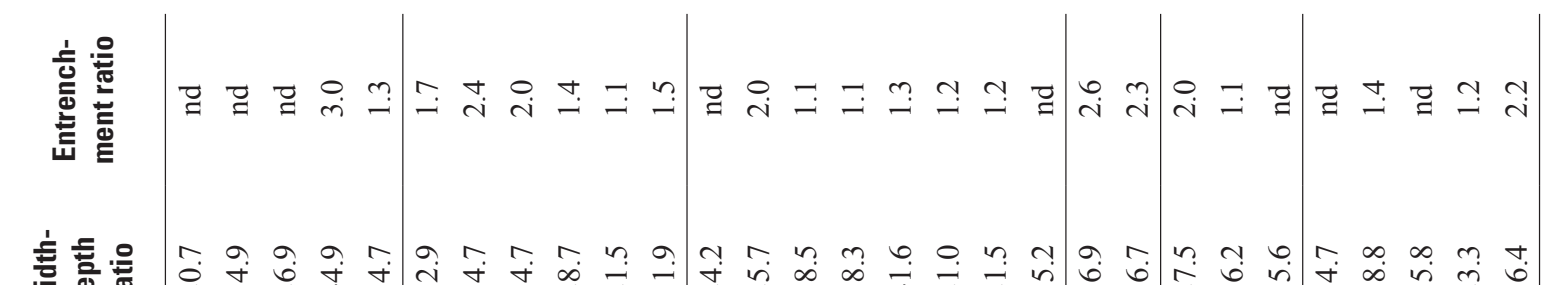
吾 竞兽

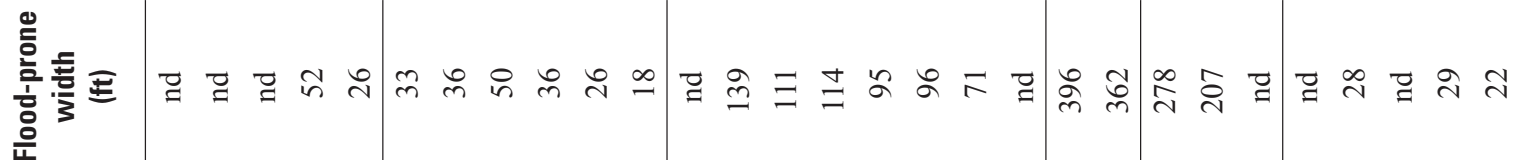

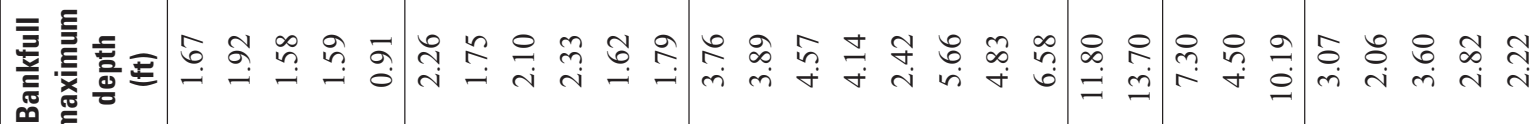

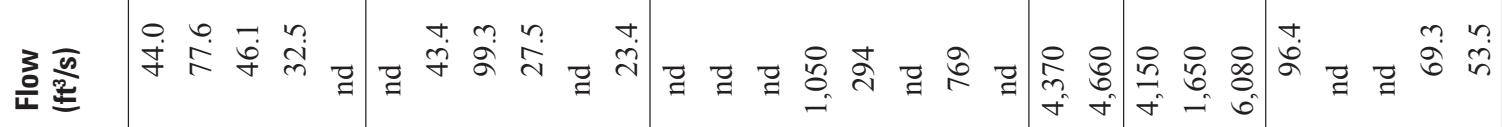

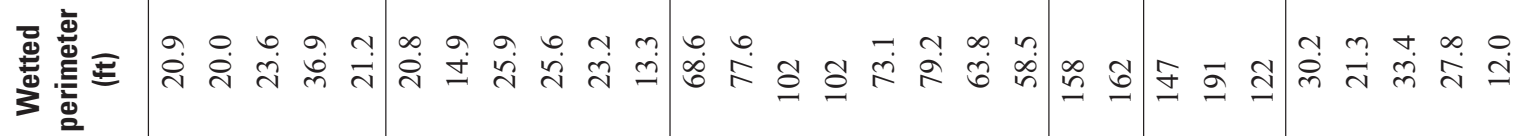

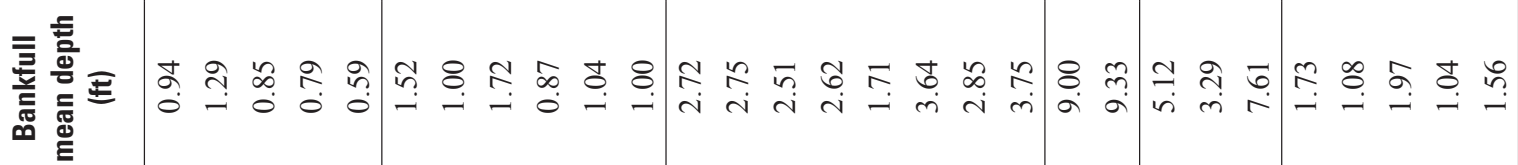

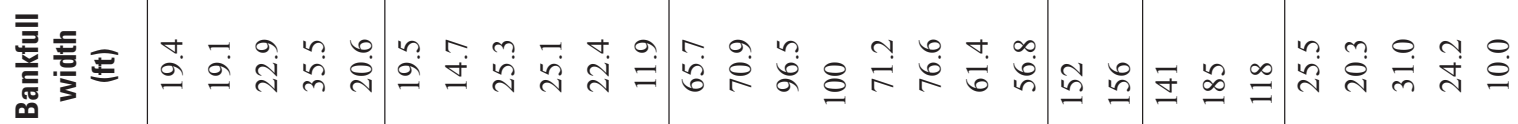

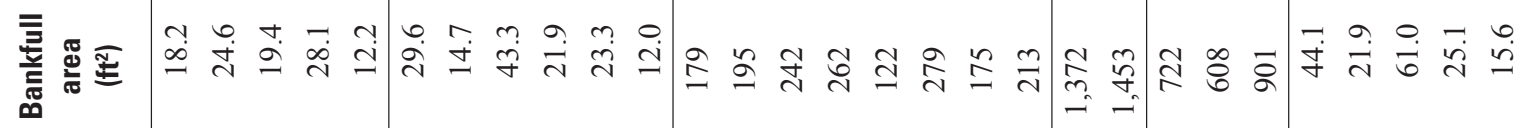

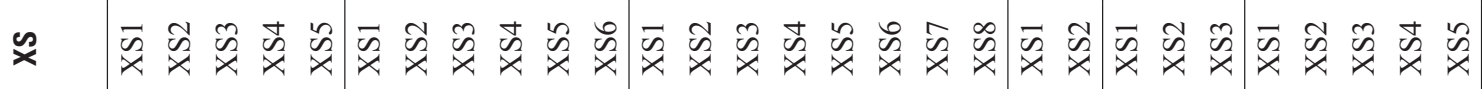

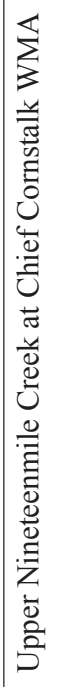

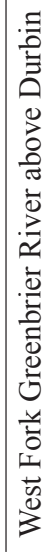

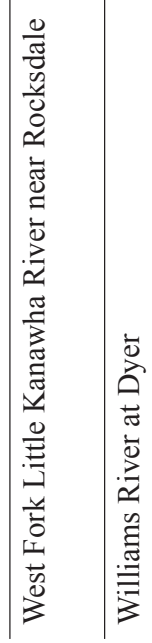

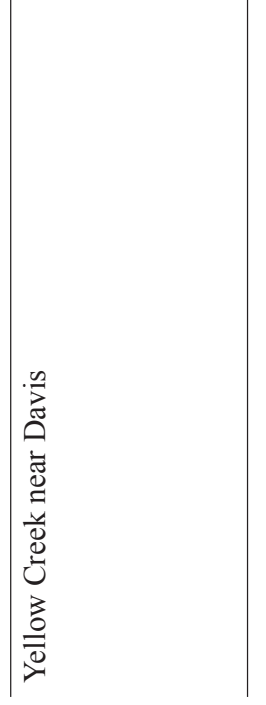



For additional information call or write to:

Director, U.S. Geological Survey

West Virginia Water Science Center

11 Dunbar Street, Charleston, WV 25301

(304) 347-5130

http://wv.usgs.gov 
